Prepared in cooperation with the Naval Facilities Engineering Command

\title{
Simulation of Zones of Groundwater Contribution to Wells South of the Naval Weapons Industrial Reserve Plant in Bethpage, New York
}

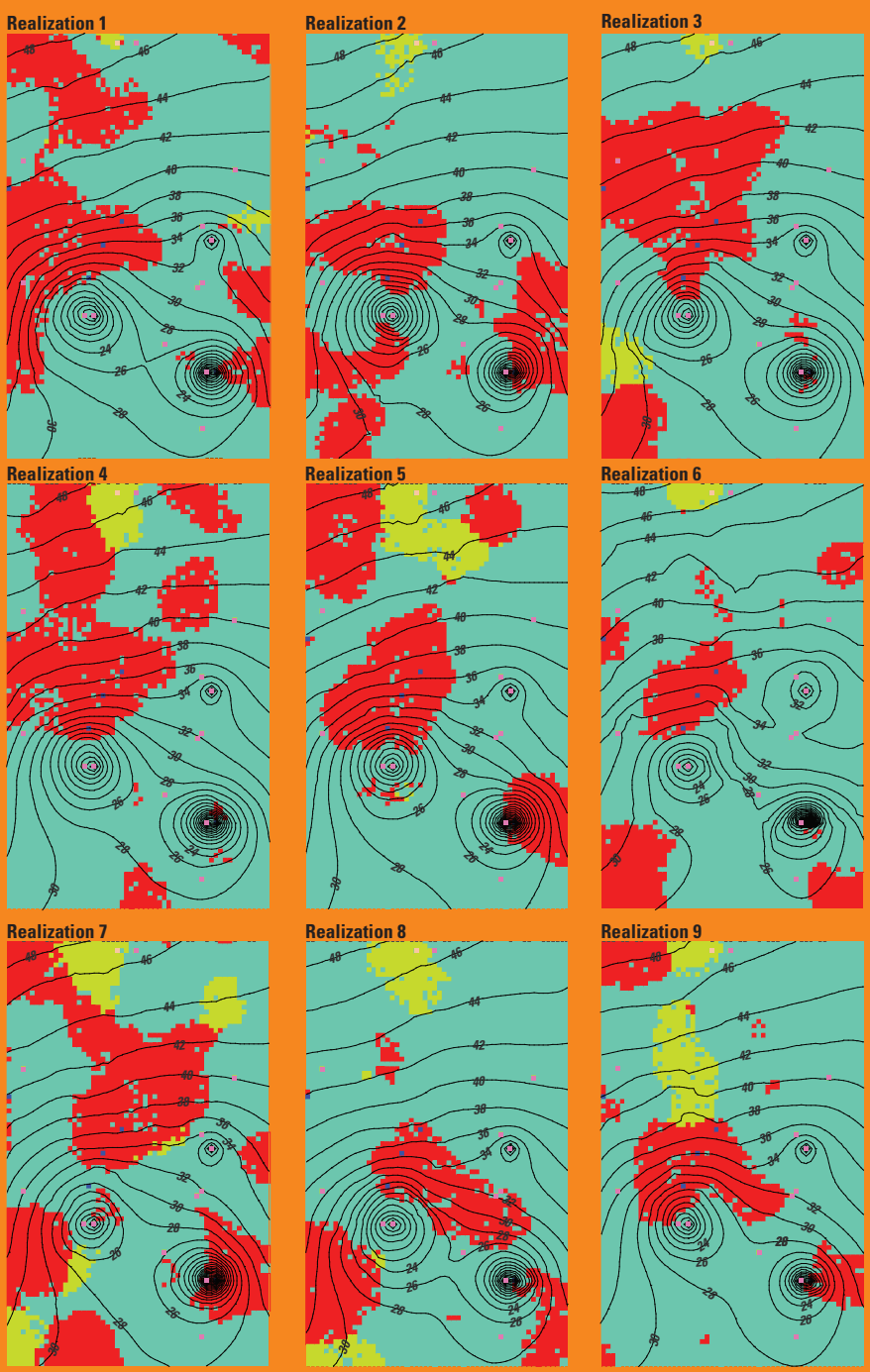

Scientific Investigations Report 2017-5161 
Cover. Map showing simulated present conditions steady-state heads at model layer 42 (-500 feet above the North American Vertical Datum of 1988) and heterogeneity realizations 1 through 9 in the focus area in Bethpage, New York; from figure 11 of this report. 


\section{Simulation of Zones of Ground water Contribution to Wells South of the Naval Weapons Industrial Reserve Plant in Bethpage, New York}

By Paul E. Misut

Prepared in cooperation with the Naval Facilities Engineering Command

Scientific Investigations Report 2017-5161 


\section{U.S. Department of the Interior \\ RYAN K. ZINKE, Secretary}

\section{U.S. Geological Survey James F. Reilly II, Director}

\section{U.S. Geological Survey, Reston, Virginia: 2018}

For more information on the USGS - the Federal source for science about the Earth, its natural and living resources, natural hazards, and the environment-visit https://www.usgs.gov or call 1-888-ASK-USGS.

For an overview of USGS information products, including maps, imagery, and publications, visit https://store.usgs.gov.

Any use of trade, firm, or product names is for descriptive purposes only and does not imply endorsement by the U.S. Government.

Although this information product, for the most part, is in the public domain, it also may contain copyrighted materials as noted in the text. Permission to reproduce copyrighted items must be secured from the copyright owner.

Suggested citation:

Misut, P.E., 2018, Simulation of zones of groundwater contribution to wells south of the Naval Weapons Industrial Reserve Plant in Bethpage, New York: U.S. Geological Survey Scientific Investigations Report 2017-5161, 45 p., https://doi.org/10.3133/sir20175161.

ISSN 2328-0328 (online) 


\section{Contents}

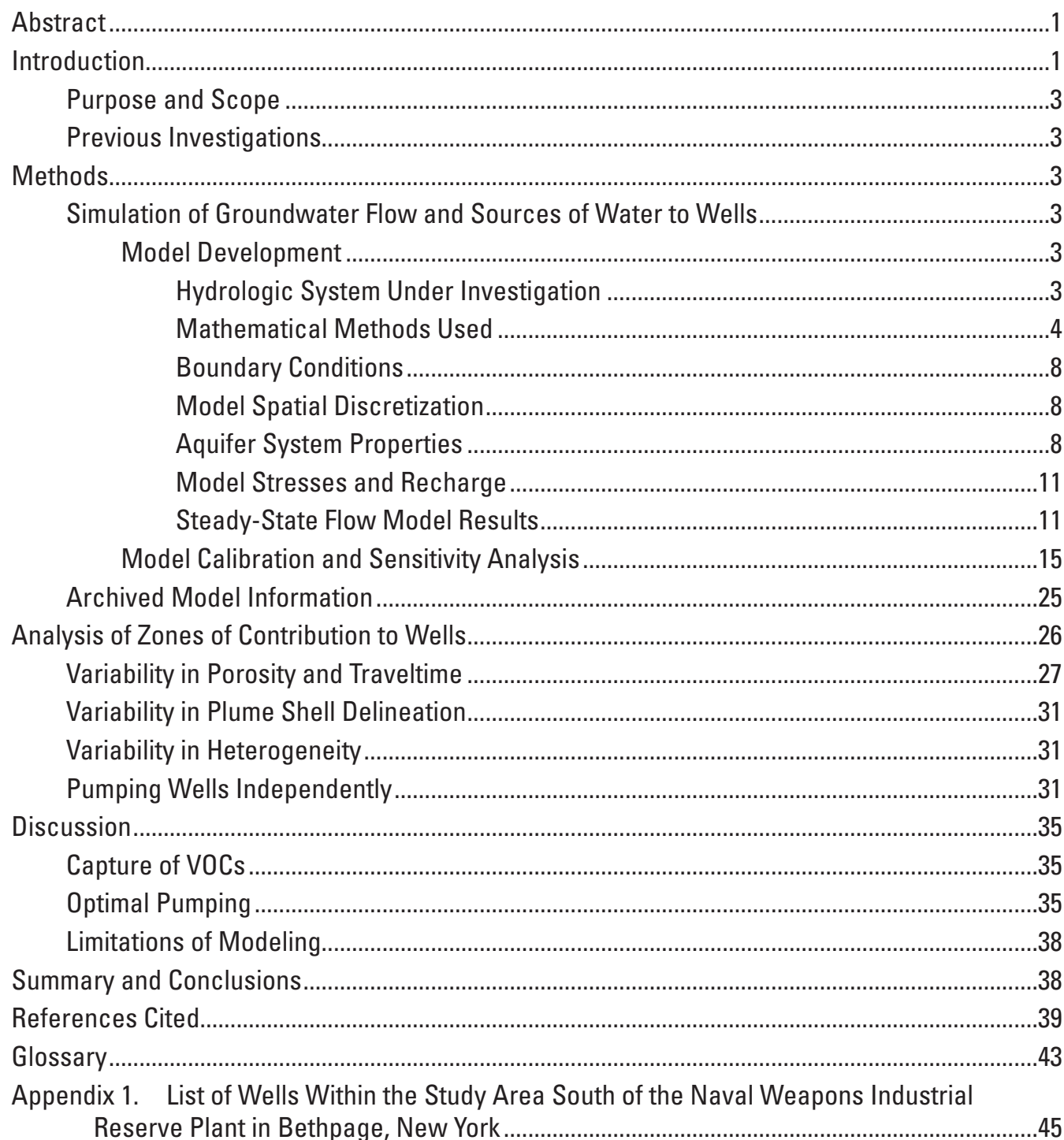




\section{Figures}

1. Map showing production wells, recharge basins, mapped volatile organic compound plumes adjacent to the Naval Weapons Industrial Reserve Plant, generalized groundwater-flow direction, and other local features in Bethpage, New York.

2. Map showing location of hydrogeologic sections $A-A^{\prime}$ and $B-B^{\prime}$ across Bethpage, New York.

3. Hydrogeologic sections showing sections $A-A^{\prime}$ and $B-B^{\prime}$ through focus area showing hydrogeologic units and borehole intervals of fine-grained sediments, Bethpage, New York

4. Map showing specified production wells in focus area, model drain cells, creeks, streamgaging stations, model constant head cells, water-level contours, no-flow model boundaries, and other features in Bethpage, New York

5. Map showing focus area of MODFLOW model grid showing row and column numbers and other local features at Bethpage, New York.

6. Section showing distribution of coarse-grained, fine-grained, and interbedded facies identified in borings and wells along sections $A-A^{\prime}$ and $B-B^{\prime}$ used in conditional simulation of Magothy aquifer heterogeneity at Bethpage, New York

7. Graphs showing probability of transitioning between facies of the Magothy aquifer at Bethpage, New York, at vertical lag distances from 2 to 30 feet..

8. Sections showing conditional realizations 1 and 2 of Magothy aquifer at Bethpage, New York, heterogeneity along cross sections $A-A^{\prime}$ and $B-B^{\prime}$

9. Block diagram showing conditional realization 1 within regional flow model with boundary conditions and other features in Bethpage, New York..

10. Maps showing present conditions steady-state heads and other features in Bethpage, New York, in $A$, regional model and $B$, the focus area using aquifer heterogeneity realization 1 .

11. Maps showing simulated present conditions steady-state heads at model layer 42 and heterogeneity realizations 1 through 9 in the focus area in Bethpage, New York

12. Map showing location of observation wells at Bethpage, New York.

13. Graph showing head time series of U.S. Geological Survey observation well N8214 at Bethpage, New York, from 1970 to 2016 and present-conditions calibration head ....24

14. Graph showing base flow as a percentage of total flow for Massapequa and Bellmore Creeks, New York

15. Graphs showing $A$, Comparison of simulated and observed water levels and $B$, composite scaled sensitivities of most sensitive parameters, corresponding to UCODE_2005 estimation of present steady-state conditions MODFLOW parameters for Bethpage, New York

16. Grid showing zones of contribution represented as projections of maximum extent of three-dimensional particle endpoints tracked backward from pumping stresses at South Farmingdale Water District wells SFWD6150, SFWD8664, SFWD8665, and Aqua NY wells ANY8480 and ANY9338 at Bethpage, New York, after 5 years, simulated using present steady-state conditions model realization 1 ......28

17. Grid showing time of travel of particles backtracked from wells at Bethpage, New York, to the 5-part-per-billion volatile organic compound plume shell

18. Box schematic showing traveltime of pathlines backtracked from well ANY8480 at Bethpage, New York, to a 5-part per billion volatile organic compound plume shell .....30 
19. Grid showing time of travel of particles backtracked from wells at Bethpage, New York, to a 5-part per billion volatile organic compound plume shell with alternate porosity and 10-year maximum traveltime

20. Grid showing maximum time of travel of particles backtracked from wells at Bethpage, New York, to 50-part per billion volatile organic compound plume shell with alternate porosity and 10 -year maximum traveltime ...

21. Grids showing aquifer heterogeneity realization 1 and traveltime of pathlines backtracked from well ANY8480 at Bethpage, New York

22. Grid showing zones of contribution represented as projections of maximum extent of three-dimensional particle endpoints tracked backward from individual pumping stresses at South Farmingdale Water District wells SFWD6150, SFWD8664, SFWD8665, and Aqua NY wells ANY8480 and ANY9338 at Bethpage, New York, after 5 years, simulated using present steady-state conditions model realization 1.

23. Grids showing traveltime and pathlines of forward-tracked particles started within interior of 50- and 5-part per billion volatile organic compound plumes

\section{Tables}

1. Characteristics of hydrogeologic units, Bethpage, New York ..........................................

2. Difference in pumping rates between Misut (2014) and present conditions models, Bethpage, New York

3. Regional model water balance, Bethpage, New York

4. Observed minus simulated residuals of calibrated present steady-state conditions model, Bethpage, New York.

5. Monitored observation wells in Bethpage, New York

6. Initial and final calibrated parameter values of a MODFLOW present steady-state conditions model, as estimated by UCODE_2005, for Bethpage, New York

7. Comparison of particle endpoints for alternate porosity and maximum traveltime simulations, Bethpage, New York

8. Comparison of particle terminations at the 5-part per billion plume shell after 5 years for alternate aquifer heterogeneity realization simulations in Bethpage, New York 


\section{Conversion Factors}

U.S. customary units to International System of Units

\begin{tabular}{lcl}
\hline \multicolumn{1}{c}{ Multiply } & By & \multicolumn{1}{c}{ To obtain } \\
\hline inch $(\mathrm{in})$. & 25.4 & millimeter $(\mathrm{mm})$ \\
foot $(\mathrm{ft})$ & 0.3048 & meter $(\mathrm{m})$ \\
square mile $\left(\mathrm{mi}^{2}\right)$ & 2.590 & square kilometer $\left(\mathrm{km}^{2}\right)$ \\
cubic foot per second $\left(\mathrm{ft}^{3} / \mathrm{s}\right)$ & 0.02832 & cubic meter per second $\left(\mathrm{m}^{3} / \mathrm{s}\right)$ \\
cubic foot per day $\left(\mathrm{ft}^{3} / \mathrm{d}\right)$ & 0.02832 & cubic meter per day $\left(\mathrm{m}^{3} / \mathrm{d}\right)$ \\
gallon per minute $(\mathrm{gal} / \mathrm{min})$ & 0.06309 & liter per second $(\mathrm{L} / \mathrm{s})$ \\
\hline
\end{tabular}

\section{Datum}

Vertical coordinate information is referenced to the National Geodetic Vertical Datum of 1929 (NGVD 29) and the North American Vertical Datum of 1988 (NAVD 88).

Horizontal coordinate information is referenced to the North American Datum of 1983 (NAD 83).

Altitude, as used in this report, refers to distance above the vertical datum.

\section{Supplemental Information}

Concentrations of chemical constituents in water are given in parts per billion (ppb).

\section{Abbreviations}

BPOW Bethpage observation well

BWD Bethpage Water District

CSS composite scaled sensitivity

DOD U.S. Department of Defense

EPA U.S. Environmental Protection Agency

IRM interim remedial measure

MODFLOW U.S. Geological Survey groundwater-flow modeling software

MODPATH U.S. Geological Survey particle tracking analysis software

NAD $83 \quad$ North American Datum of 1983

NAVD $88 \quad$ North American Vertical Datum of 1988

NAWQA National Water Quality Assessment

NCDH Nassau County Department of Health

NGVD 29 National Geodetic Vertical Datum of 1929 


$\begin{array}{ll}\text { NWIRP } & \text { Naval Weapons Industrial Reserve Plant } \\ \text { NYSDEC } & \text { New York State Department of Environmental Conservation } \\ \text { OU } & \text { operable unit } \\ \text { ppb } & \text { part per billion } \\ \text { SPDES } & \text { State Pollutant Discharge Elimination System } \\ \text { T-PROGS } & \text { transitional probability geostatistical software } \\ \text { TVOC } & \text { total volatile organic compound } \\ \text { UCODE_2005 } & \text { universal sensitivity analysis, calibration, and uncertainty evaluation software } \\ \text { USGS } & \text { U.S. Geological Survey } \\ \text { VOC } & \text { volatile organic compound } \\ \text { VPB } & \text { vertical profile boring } \\ \text { ZOC } & \text { zone of contribution }\end{array}$





\title{
Simulation of Zones of Groundwater Contribution to Wells South of the Naval Weapons Industrial Reserve Plant in Bethpage, New York
}

\author{
By Paul E. Misut
}

\section{Abstract}

A steady-state three-dimensional groundwater-flow model that simulates present conditions was coupled with the particle-tracking program MODPATH to delineate zones of contribution to wells pumping from the Magothy aquifer near a chlorinated volatile organic compound (VOC) plume. This modeling was part of a study by the U.S. Geological Survey in cooperation with the Naval Facilities Engineering Command to delineate groundwater near the Naval Weapons Industrial Reserve Plant in Bethpage, New York. Because rates of advection within the coarse-grained sediments typically exceed 0.1 foot per day, transport by dispersion and (or) diffusion was assumed to be negligible. Resulting zones of contribution are complex shapes, influenced by hydrogeologic features including confining beds and a basal gravel zone, and the interplay of nearby hydrologic stresses. The use of two particle tracking techniques identified zones of contribution to wells. Particles are backtracked from pumping well screens, and particles are forward tracked from the location of a VOC plume, as defined by surfaces of equal total VOC concentration. During any period of 5 years or less, about 1 to 3 percent of particles backtracked from pumping wells within a focus area intersected the 5-part per billion (ppb) VOC plume shell, indicating that the vast majority of particles were not sourced from the plume. During 5 years or less, none of the particles backtracked from pumping wells intersected the 50-ppb VOC plume shell. Forward-tracking techniques identified the fate of water within the VOC plume after 5 years as it moves toward ultimate well capture and (or) discharge to model constant head and drain boundaries. Out of 4,813 forward tracked particles started within the 50-ppb VOC plume shell, 1 forward-tracked particle was captured by well ANY8480. Out of 22,958 forward tracked particles started within the 5-ppb VOC plume shell, 100 were captured by production wells (less than 1 percent). The subset of forward pathlines that represent well plume capture are similar in number and shape to those of backtracked pathlines.

Model simulations were conducted to assess uncertainties and improve understanding of how variability in hydraulic properties, pumpage rates, and maximum particle traveltime affect delineation of zones of contribution. By use of driller's' logs, a transitional probability approach generated nine alternative realizations of heterogeneity within the Magothy aquifer to assess uncertainty in model representation. Finegrained sediments with low hydraulic conductivity were realized as laterally discontinuous, thickening towards the south, and comprising about 27 percent of the total aquifer volume within the transitional probability subgrid. Model simulations with alternative pumpage rates, porosity terms, and alternative maximum particle traveltime were also used to demonstrate how the size and shape of zones of contribution may vary.

\section{Introduction}

Several plumes ${ }^{1}$ of dissolved volatile organic compounds (VOCs), including trichloroethylene (TCE), were identified by the U.S. Geological Survey (USGS) in cooperation with the Naval Facilities Engineering Command in a semiconfined aquifer near the Naval Weapons Industrial Reserve Plant (NWIRP) at Bethpage, New York (fig. 1). The operable unit (OU) plume OU2 is generated to the south of the NWIRP, and in 2003, the Navy issued a record of decision for OU2, which presently consists of plume remnants to the south and west of the NWIRP (Naval Facilities Engineering Command, 2003). Since 1950, the downgradient edge of the OU2 plume has been estimated to travel about 285 feet per year (ft/yr) on average (Harre and others, 2011). At present, about 3,500 gallons per minute ( $\mathrm{gal} / \mathrm{min}$ ) of water is pumped from an OU2 onsite hydraulic containment system. Groundwater captured at the onsite hydraulic containment system is piped to an air stripping and vapor phase granular activated carbon adsorption plant, treated to New York State Department of Environmental Conservation (NYSDEC) State Pollutant Discharge Elimination System (SPDES) standards, then transferred to recharge basins where the effluent percolates downward and reenters the groundwater system. Production wells that pump from the Magothy aquifer downgradient of the OU2 onsite hydraulic containment system include South Farmingdale Water District wells SFWD6150, SFWD8664, and SFWD8665 and Aqua

${ }^{1}$ Terms in bold are defined in the glossary. 


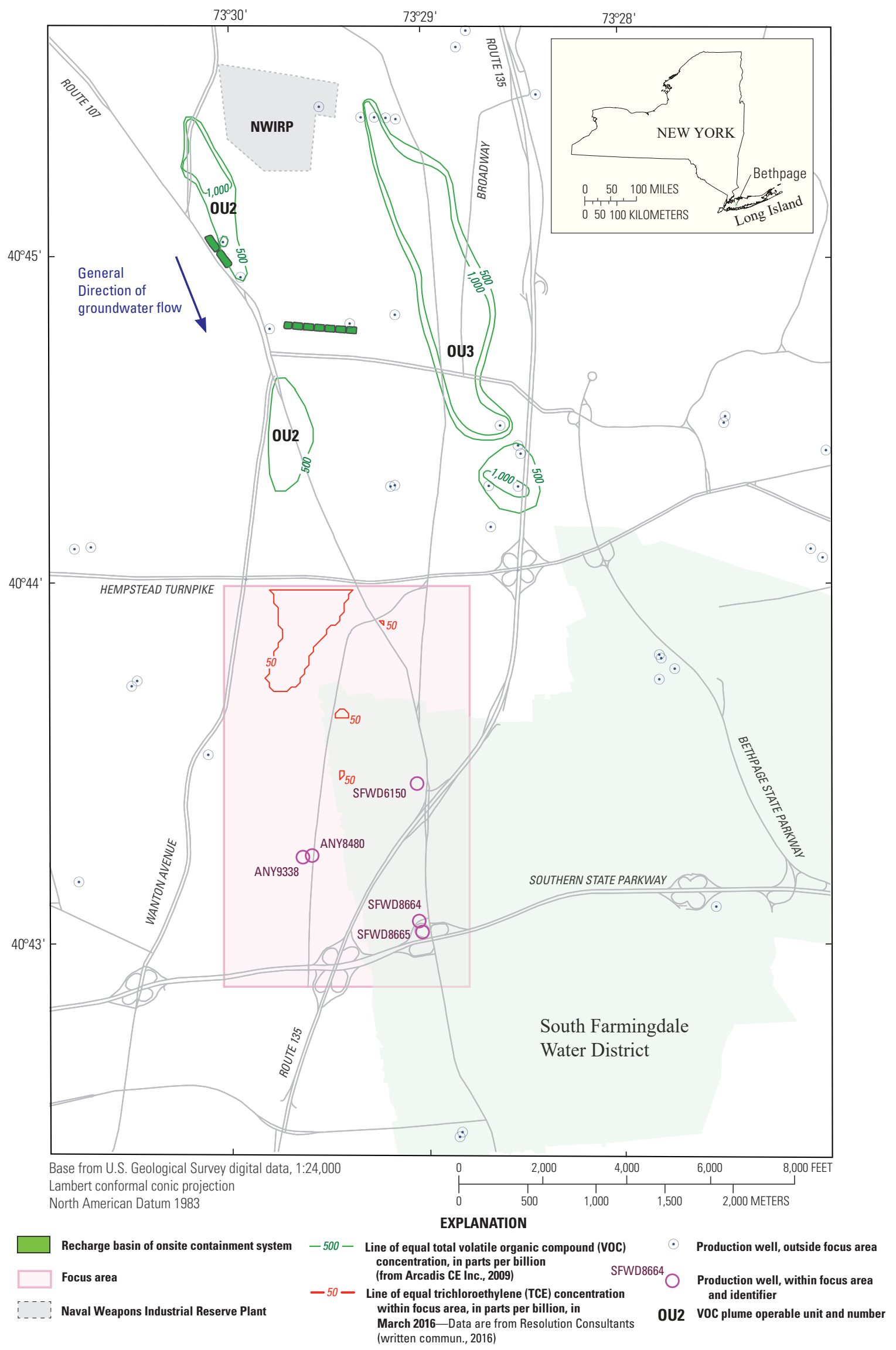

Figure 1. Production wells, recharge basins, mapped volatile organic compound plumes adjacent to the Naval Weapons Industrial Reserve Plant (NWIRP), generalized groundwater-flow direction, and other local features in Bethpage, New York. 
NY wells ANY8480 and ANY9338 (fig. 1). Identification and better understanding of factors affecting the zones of contribution (ZOCs) to these wells is needed for their protection and management.

\section{Purpose and Scope}

This report presents the results of a study undertaken to provide a better understanding of ZOCs of wells within a focus area (fig. 1) of a regional model grid. The study evaluated advective groundwater-flow patterns through groundwater-flow simulation and particle-tracking analysis in forward and backward modes. The groundwater-flow simulation and particle-tracking analysis had the following general objectives:

- Delineate ZOCs based on present conditions through backwards tracking of particles that are initiated at wells.

- By use of hypothetical simulations, determine hydrogeologic and pumping-rate controls on the size and shape of ZOCs.

The report contains a description of simulations and analyses that meet the study objectives. As a result of simulation analysis, further field-data collection activities that may result in improved ZOC delineation are discussed. A discussion of the limitations of this approach is also included.

Representation of plume source loading mechanisms such as contaminant inflow was beyond the scope of the study. Simulations described in this report do not characterize the historical development of any plume.

\section{Previous Investigations}

Simulation of the groundwater-flow system of Nassau County began before the advent of computers through the use of electric-analog models (Getzen, 1977). Smolensky and Feldman (1995) simulated groundwater-flow paths in the Bethpage area in cooperation with the Nassau County Department of Health (NCDH) through the use of the USGS codes MODFLOW (McDonald and Harbaugh, 1988) and MODPATH (Pollock, 1989). At the time of the first MODFLOW analysis, groundwater flowed towards deep industrial pumping wells and away from surface recharge basins where water captured by industrial wells was reintroduced. A pumpingrecharge open geothermal cooling loop resulted in rearrangement and partial containment of a plume of VOCs, which was migrating in a generally southward direction at a rate of about $200 \mathrm{ft} / \mathrm{yr}$, as described by Smolensky and Feldman (1995).

The analysis also indicated that some groundwater upgradient of surface recharge basins was drawn into the deep zones of industrial well influence, but not captured, and ultimately discharged to the far southern model boundary in the bottom part of the Magothy aquifer, near the contact with the underlying Raritan confining unit as described by Smolensky and Feldman (1995). From 1995 to the present [2017], a series of
MODFLOW, MODPATH, and MT3D models were developed (Zheng, 1990) that are generally consistent with the earlier USGS work but depict greater containment of VOCs upgradient of the onsite hydraulic containment system and continued southward migration of VOCs downgradient from the onsite hydraulic containment system (Arcadis CE, Inc., 2009, 2010). A timeline of the modeling efforts is given in Misut (2011). Misut (2014) also conducted a particle tracking analysis of the OU3 area (fig. 1), which is in general agreement with previous studies.

\section{Methods}

Simulation of groundwater flow and advective transport included steady-state flow modeling using USGS codes. Generation of alternate equiprobable hydraulic property distributions uses transitional probability methods (Carle, 1999).

\section{Simulation of Groundwater Flow and Sources of Water to Wells}

The numerical calculations of the various ZOC cases investigated in this study are carried out using the USGS MODFLOW-2005 suite of codes (Harbaugh, 2005) coupled with MODPATH version 6 (Pollock, 2012). The model is documented according to USGS guidelines (U.S. Geological Survey, 1996). Because of the use of transitional probability methods (Carle, 1999) to represent Magothy aquifer heterogeneity, the MODFLOW model was finely discretized into 65 layers in the subdomain of heterogeneity representation.

\section{Model Development}

To fully describe the groundwater-flow model, the following topics are introduced: hydrologic system under investigation, mathematical methods used, model spatial and temporal discretization, aquifer system properties, stresses modeled, calibration criteria, procedure, and results, and limitations of the model of the actual system and the impact those limitations have on the results and conclusions of the report. Parameters are assigned for aquifer and confining unit hydraulic properties, and for boundary condition fluxes and conductances.

\section{Hydrologic System Under Investigation}

The Bethpage area is situated within the Long Island groundwater system, which has been described in previous USGS publications (Smolensky and Feldman, 1995; Busciolano, 2005; Misut and Busciolano, 2009). The aquifer and confining units in the Bethpage area are described in table 1 . The average horizontal hydraulic conductivity of the upper glacial, Magothy, and Lloyd aquifers is 270, 50, and 60 feet per day $(\mathrm{ft} / \mathrm{d})$, respectively. The estimated ratio 
Table 1. Characteristics of hydrogeologic units, Bethpage, New York.

\begin{tabular}{|c|c|c|}
\hline Hydrogeologic unit & Geologic unit & Description and hydraulic properties \\
\hline Upper glacial aquifer & Upper Pleistocene deposits & $\begin{array}{l}\text { Till and outwash deposits of sand, silt, clay, and boulders. Varied permeability with } \\
\text { an average hydraulic conductivity of } 270 \text { feet per day and a horizontal to verti- } \\
\text { cal anisotropy of 10:1. Outwash has the highest hydraulic conductivity. About } \\
100 \text { feet thick. }\end{array}$ \\
\hline Magothy aquifer & $\begin{array}{l}\text { Matawan Group-Magothy } \\
\text { Formation, undifferentiated }\end{array}$ & $\begin{array}{l}\text { Fine sand with silt and interbedded clay, with basal gravel. Gray and pale yellow } \\
\text { quartz sand. Lignite is common. Moderately permeable with an average hydraulic } \\
\text { conductivity of } 50 \text { feet per day and an anisotropy of 100:1. About } 800 \text { feet thick. }\end{array}$ \\
\hline $\begin{array}{l}\text { Raritan confining unit } \\
\text { (Raritan clay) }\end{array}$ & $\begin{array}{l}\text { Unnamed clay member of the } \\
\text { Raritan Formation }\end{array}$ & $\begin{array}{l}\text { Clay; solid with gray, white, red, or tan colors. Very poorly permeable. Confines } \\
\text { water underlying unit. Average hydraulic conductivity of } 0.001 \text { foot per day. } \\
\text { About } 200 \text { feet thick. }\end{array}$ \\
\hline Lloyd aquifer & $\begin{array}{l}\text { Lloyd Sand Member of the } \\
\text { Raritan Formation }\end{array}$ & $\begin{array}{l}\text { Underlies the Raritan confining unit. Fine to coarse sand and gravel with clay } \\
\text { lenses. White and pale-yellow sand well sorted. Moderately permeable with an } \\
\text { average horizontal hydraulic conductivity of } 60 \text { feet per day, and anisotropy of } \\
\text { 10:1. About } 200 \text { feet thick. }\end{array}$ \\
\hline Bedrock & $\begin{array}{l}\text { Hartland Formation; crystal- } \\
\text { line bedrock }\end{array}$ & $\begin{array}{l}\text { Biotite-garnet schist overlain by a thick saprolitic zone } 50 \text { to } 100 \text { feet thick, consist- } \\
\text { ing of white, yellow, and gray clay. Impermeable to poorly permeable. }\end{array}$ \\
\hline
\end{tabular}

of horizontal to vertical hydraulic conductivity is $10: 1$ for the upper glacial and Lloyd aquifers and 100:1 for the Magothy aquifer. Locally, borings penetrated a gravel zone within the basal Magothy aquifer (Resolution Consultants, written commun., 2016). The average horizontal hydraulic conductivity of the gravel zone is believed to be greater than $120 \mathrm{ft} / \mathrm{d}$, which is the estimated value corresponding to a deep zone of the Magothy aquifer defined to include a gravel zone and other less permeable zones (Resolution Consultants, written commun., 2016).

Precipitation is the dominant source of water that recharges the groundwater system. Recharge to the groundwater system is from precipitation that infiltrates downward through an unsaturated zone. Recharge is locally enhanced by constructed recharge basins. Factors affecting rates of recharge include spatial and temporal variations in precipitation, permeability of surficial hydrogeologic units, land-cover characteristics, and discharge of domestic and industrial wastewater. Annual average precipitation is about 42 inches (Miller and Fredrick, 1969). Under predevelopment conditions, about 50 percent of the precipitation reached the water table, mainly during the nongrowing season (Seaburn and Aronson, 1974; McClymonds and Franke, 1972). Under present conditions, recharge is mainly from infiltration of precipitation through unpaved areas, and infiltration through recharge basins.

Groundwater enters and exits the area by lateral flow from the regional Long Island system. Discharge from the groundwater system is to pumping wells and gaining streams that occupy former glacial meltwater channels, including Massapequa Creek, Bellmore Creek, and Seaford Creek.

Across the study area, the upper glacial aquifer is unconfined except in the north, where the upper glacial aquifer is unsaturated and the water table is in the deeper semiconfined Magothy aquifer. Even though the uppermost aquifer is the glacial aquifer, the Magothy aquifer is the primary water supply aquifer and aquifer of concern for VOCs. Within the Magothy aquifer, sands and gravels are interbedded with fine-grained sediments. Fine-grained sediments, as reported on driller's' logs, are delineated on sections $A-A^{\prime}$ and $B-B^{\prime}$ (figs. 2 and 3).

The top of the Raritan confining unit, at about 900 to 950 feet (ft) below sea level, or the relatively impermeable bedrock, at about 1,200 to $1,300 \mathrm{ft}$ below sea level was considered the lower boundary of the local groundwater subsystem (table 1). The Raritan confining unit is estimated to be 150 to $200 \mathrm{ft}$ thick in the region (Smolenksy and others, 1989). However, its presence was not confirmed at vertical profile boring VPB-129, and the depth of top surface at VPB-132 was found to be greater than estimated. The regional hydraulic gradient from the Lloyd aquifer across the Raritan confining unit into the Magothy aquifer is about 0.03 [ft per $\mathrm{ft}$ ] upward near Bethpage (Monti and others, 2013). Given a Raritan confining unit vertical conductivity of about $0.001 \mathrm{ft} / \mathrm{d}$, upward flow from the Raritan confining unit into the Magothy aquifer is likely negligible (less than 1 percent of groundwater recharge to an equivalent area), except where it is absent.

\section{Mathematical Methods Used}

The numerical calculations of the ZOC cases investigated in this study are carried out using flow fields represented by a finite difference grid and simulated by the MODFLOW-2005 suite of codes (Harbaugh, 2005) through solution of the groundwater flow equation using finite difference techniques. Particles are tracked through the simulated flow fields using MODPATH version 6 (Pollock, 2012). The graphical user interface ModelMuse (Winston, 2009) is used to aid the input of data and the postprocessing of model results. The MODFLOW suite represents three-dimensional geometry 

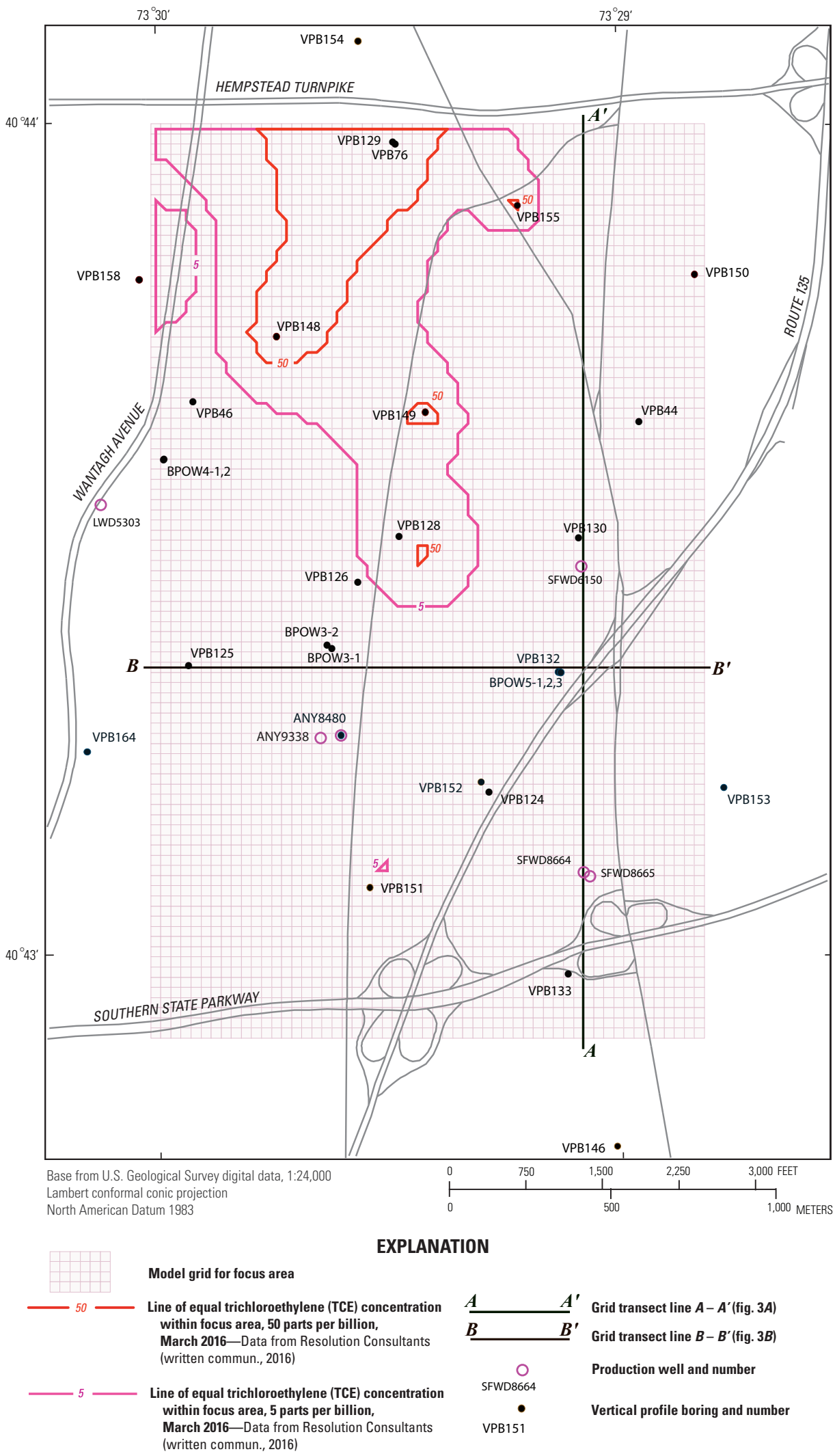

Figure 2. Location of hydrogeologic sections $A-A^{\prime}$ and $B-B^{\prime}$ across Bethpage, New York. Location of focus area shown on figure 1. 


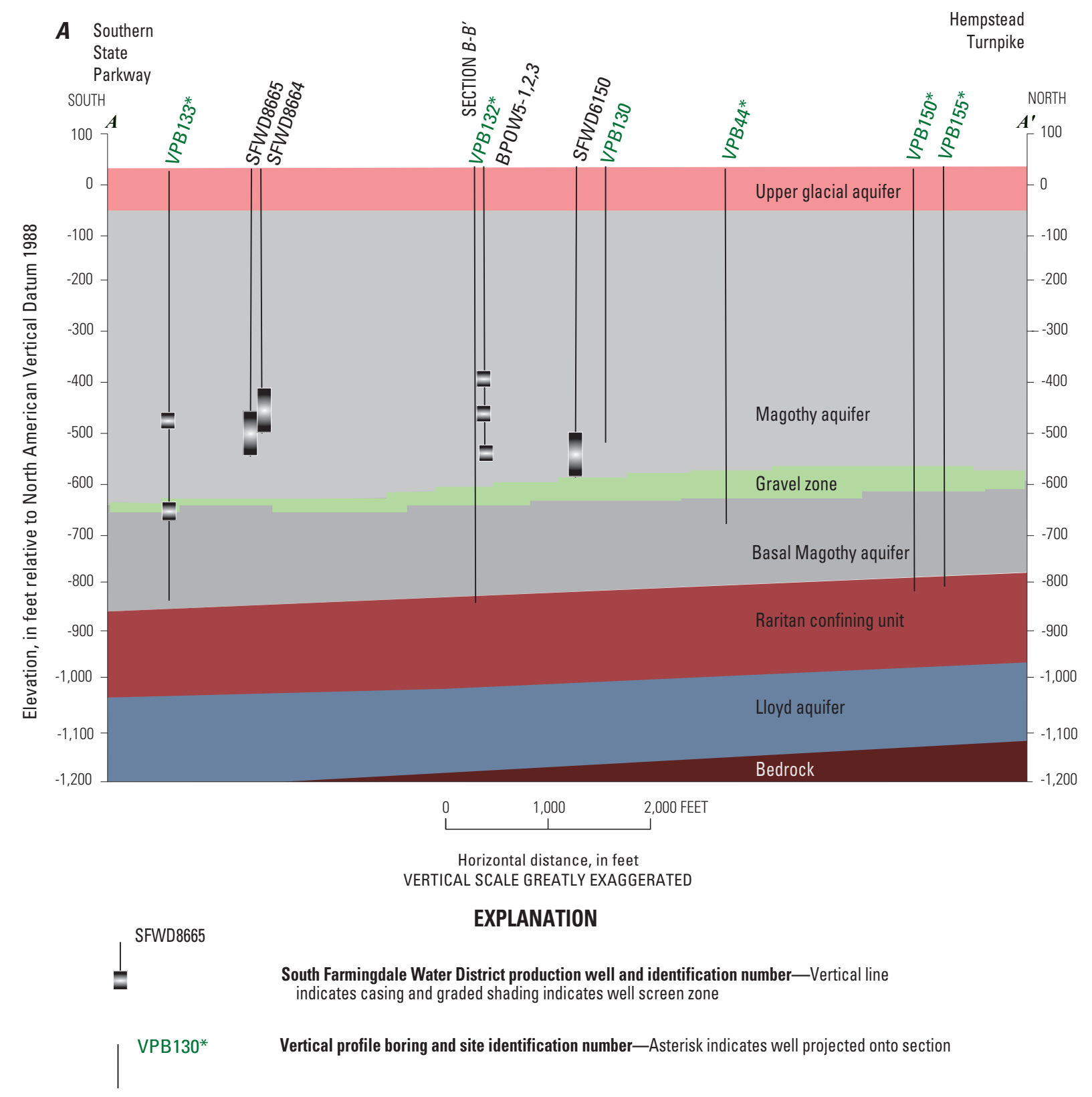

Figure 3. Sections $A, A-A^{\prime}$ and $B, B-B^{\prime}$ through focus area showing hydrogeologic units and borehole intervals of finegrained sediments, Bethpage, New York. Location of cross-section lines shown on figure 2. Data are from Smolensky and others (1989), Tetra Tech (2012a), David Brayack (Tetra Tech, written commun., 2013), and Brian Caldwell (Resolution Consultants, written commun., 2016). 


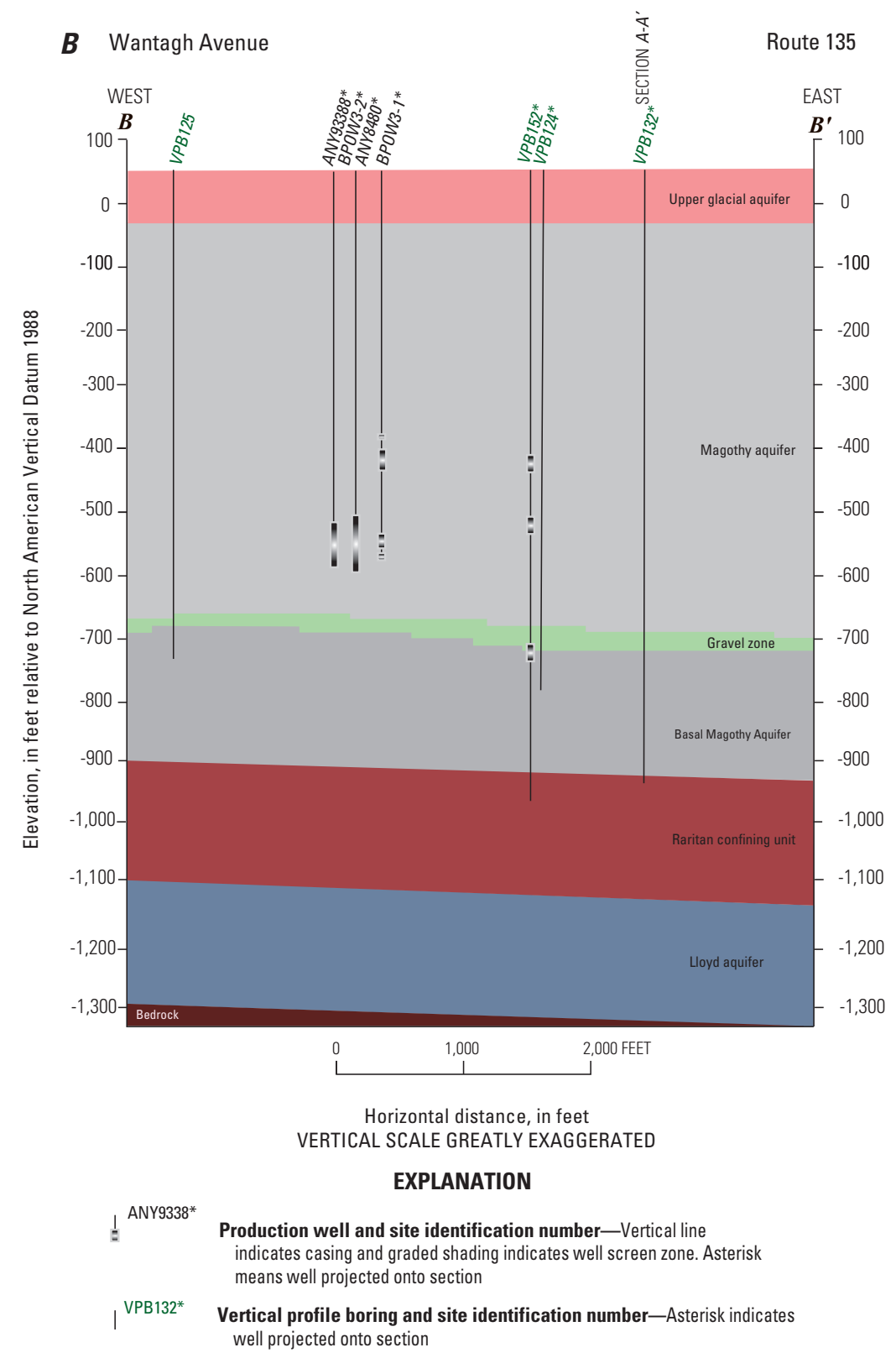

Figure 3. Sections $A-A^{\prime}$ and $B-B^{\prime}$ through focus area showing hydrogeologic units and borehole intervals of fine-grained sediments, Bethpage, New York. Location of cross-section lines shown on figure 2. Data are from Smolensky and others (1989), Tetra Tech (2012a), David Brayack (Tetra Tech, written commun., 2013), and Brian Caldwell (Resolution Consultants, written commun., 2016).-Continued 
and complex boundary conditions, allows for variably spaced model discretization, and can be used by particle tracking methods to delineate ZOCs to wells.

Particle tracking evaluations were made for representative modern steady-state conditions using MODPATH version 6 (Pollock, 2012), which accounts for advective transport but does not consider dispersive transport or chemical reactions. Advective particle tracking was used to develop the ZOCs for the study area. Dispersion from molecular diffusion is assumed to be negligible. Changes to traveltime related to geologic heterogeneity was accounted for by considering multiple realizations of the distribution of hydrogeologic properties.

The transition probability geostatistical software T-PROGS (Carle, 1999) was used to generate alternative realizations representing zones of high-permeability sands and low-permeability clays within the Magothy aquifer. Transition probability and Markov chain methods use geologic data to compute the probability that a particular geologic unit is penetrated given the location of nearby geologic units. Twentythree boring logs were distributed throughout the focus area (figs. 1 and 2) with density of about 13 logs per square mile. Once the probabilities are computed, equiprobable realizations of hydrogeologic properties can be created based on the known lithologies in the boreholes. This method ensures the model matches reality at all measured locations and matches the statistics of the system at all unmeasured locations.

\section{Boundary Conditions}

The northern and southern boundaries of the groundwater-flow model (fig. 4) are represented as constant-head boundaries. The eastern and western model boundaries are represented as no-flow boundaries where flow is generally parallel to the active boundary. Head values for the boundary conditions are estimated from 2013 regional contour maps, which are representative of present steady-state conditions (Como and others, 2016). Recharge is a specified flux boundary with several factors affecting the rate, as described by the model stresses section below. MODFLOW drain boundaries are used to represent three streams draining to the south of the model (Massapequa, Seaford, and Bellmore Creeks). The constant heads for these drains are also taken from Como and others (2016). Flow at Massapequa and Bellmore Creeks is reported at U.S. Geological Survey (2017c). Pumpages are specified flux boundaries and are described in the "Model stresses" section.

\section{Model Spatial Discretization}

The areal extent of the model grid (fig. 4) is similar to that described by Arcadis CE, Inc. (2010), with finer grid spacing in the vicinity of a focus zone that includes public-supply production wells SFWD6150, SFWD8664, SFWD8665, and Aqua NY wells ANY8480 and ANY9338. The total number of rows (127) and columns (89), along with the number of model layers (70), results in about 800,000 cells. In the outlying zone, model cell dimensions generally range from $1,800 \mathrm{ft}$ by $1,800 \mathrm{ft}$ horizontally in corners to $100 \mathrm{ft}$ by $100 \mathrm{ft}$ in the focus area. Layers extend horizontally from the focus zone outwards to the regional model domain boundary. For the focus zone (inner region of model grid with 54 columns by 89 rows by 65 layers of $100 \mathrm{ft}$ by $100 \mathrm{ft}$ by $10 \mathrm{ft}$ cells; fig. 5), the Magothy aquifer heterogeneity is represented using the transitional probability approach, and particle tracking of production well ZOCs are conducted. Fine horizontal and vertical discretization is necessary in the focus zone to represent the discontinuous character of the fine-grained sediments and to simulate the influence of these structures on particle pathways. The grid layering is coarse in the upper glacial aquifer (generally two layers with average thickness of $100 \mathrm{ft}$ ), fine in the Magothy aquifer (focus area thickness of $10 \mathrm{ft}$ ), and coarse in the Raritan formation (generally three layers with average thickness of $200 \mathrm{ft}$ ). The bottom of the top layer is at sea level, a conservative level below the water table that prevents model cells from dewatering, which would introduce nonlinearity into the MODFLOW numerical solution. The top of the plume is located within the finely discretized focus zone of the Magothy aquifer. The bottom no-flow boundary of the model is chosen to be the base of unconsolidated deposits (base of the Lloyd aquifer of the Raritan Formation) in order to fully represent the groundwater flow system, as has been done by other Nassau County groundwater flow models such as (Misut and Aphale, 2014).

\section{Aquifer System Properties}

Aquifer system properties are summarized in table 1 and include three geologic units: upper Pleistocene deposits, Magothy Formation, and Raritan Formation. Aquifer properties are discussed in Smolenksy and Feldman (1995), McClymonds and Franke (1972), Smolensky and others (1989), and Arcadis CE, Inc. (2003). Initial hydraulic conductivity values were estimated for the hydrogeologic units using specificcapacity data with drillers' logs and other methods that are summarized in McClymonds and Franke (1972). The initial effective porosity value for all model layers is 0.25 based on (Arcadis CE, Inc., 2011; Misut, 2011). Storage parameters applied in previous modeling studies on Long Island are summarized by Buxton and Smolenksy (1999), with specific yield values ranging from 0.1 (Magothy aquifer) to 0.3 (glacial outwash) and a specific storage of $6.0 \times 10^{-7}[1 / \mathrm{ft}]$ for all confining units. Misut and Busciolano (2009) estimated the specific storage of the upper Magothy to be $5.0 \times 10^{-6}[1 / \mathrm{ft}]$. Simulated aquifer system properties were refined during model calibration as data became available through an ongoing U.S. Department of the Navy drilling program (Resolution Consultants, written commun., 2016), including addition of a basal gravel zone within the Magothy aquifer and lowering the altitude of top of the Raritan confining unit. The horizontal and vertical hydraulic conductivity of the Raritan confining unit is specified as $0.001 \mathrm{ft} / \mathrm{d}$ (isotropic), following Buxton and Smolensky (1999). 


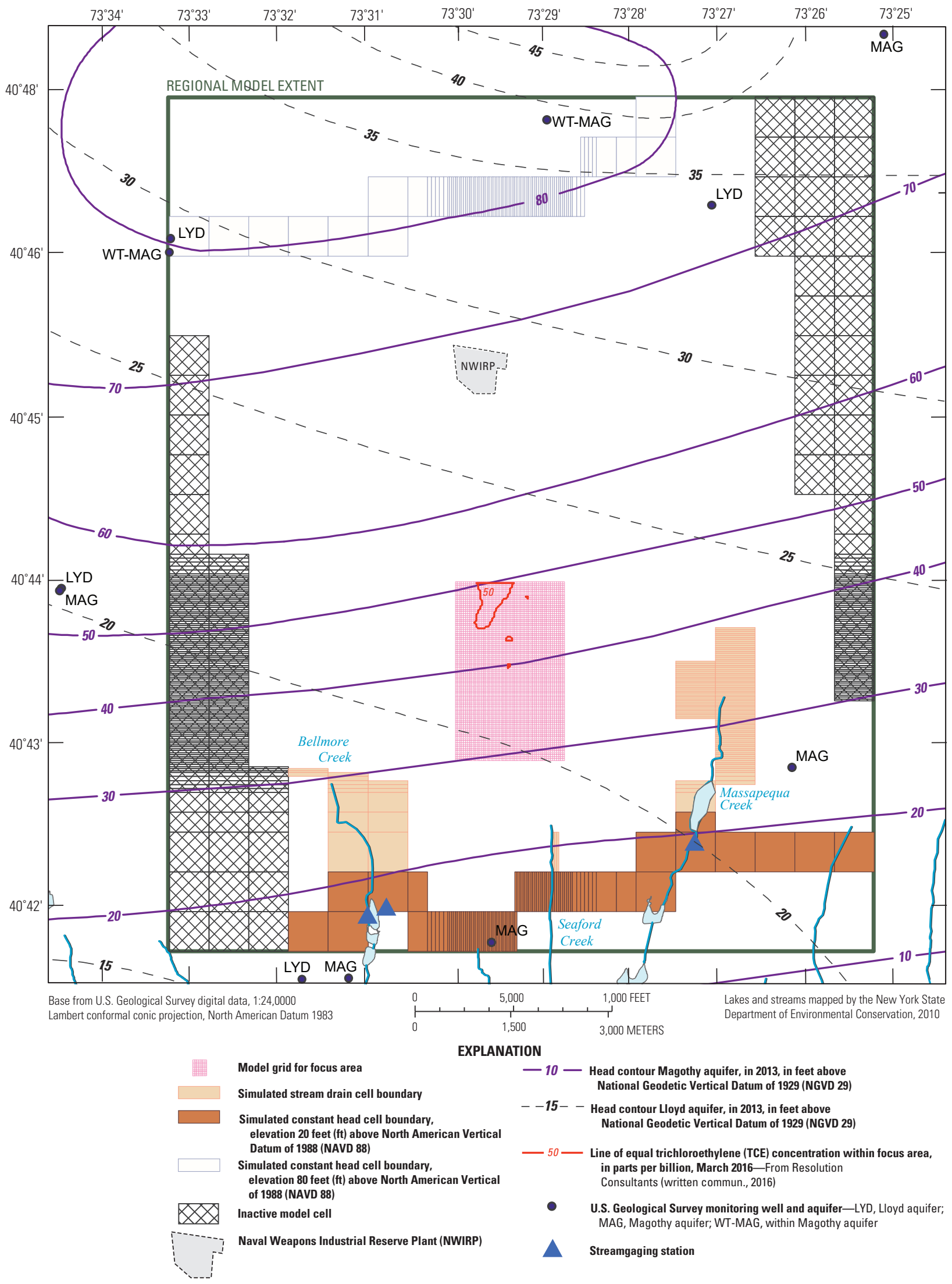

Figure 4. Specified production wells in focus area, model drain cells, creeks, streamgaging stations, model constant head cells, water-level contours, no-flow model boundaries, and other features in Bethpage, New York. 


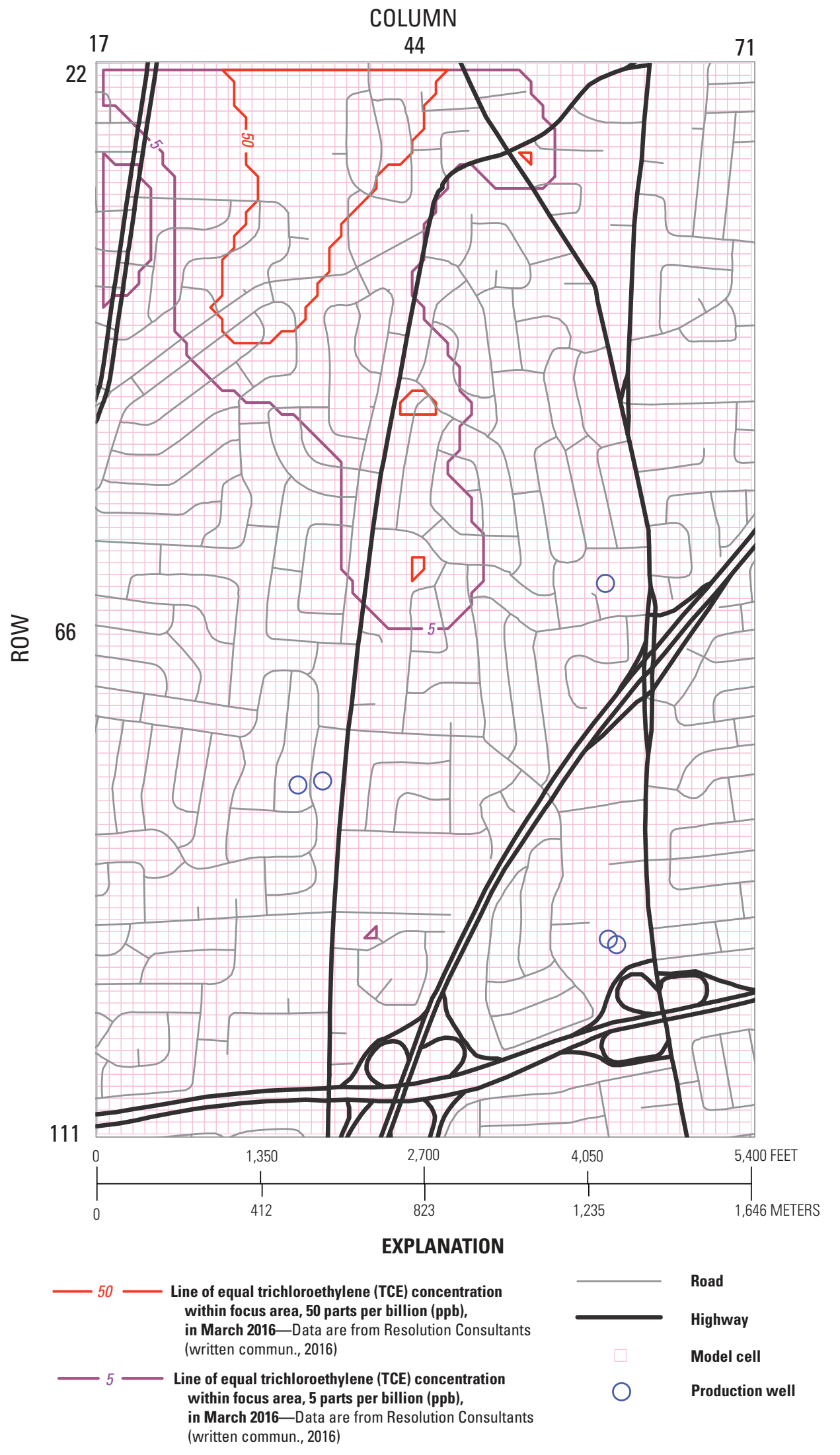

Figure 5. Focus area of MODFLOW model grid showing row and column numbers and other local features at Bethpage, New York. Location of focus area shown in figure 1. 
Initial parameter values for the main part of the Magothy aquifer included a horizontal hydraulic conductivity of $50 \mathrm{ft} / \mathrm{d}$ and a vertical hydraulic conductivity of $0.5 \mathrm{ft} / \mathrm{d}$. These values relate to implicit representation of local confining layers within the Magothy aquifer through a vertical anisotropy factor (ratio of horizontal to vertical hydraulic conductivity) of 100:1. However, local confining layers within the focus area (figs. 1 and 5) of the Magothy aquifer are further represented as a sequence of nine conditional stochastic simulations - equally probable spatial distributions that represent the borehole data shown in figure 3 . These distributions were not screened from a larger population of distributions and therefore do not represent a Monte Carlo analysis; they are simply the only randomly selected distributions generated; each provides a reasonable match to the observed data and interpretations of confining bed structures.

Sedimentary facies in the Magothy aquifer identified (Tetra Tech 2012a, 2012b; Resolution Consultants, written commun., 2016) in the borings and the monitoring and public-supply wells include coarse-grained sediments, finegrained sediments, and interbedded coarse and fine-grained sediments. Twenty-three boring logs were distributed throughout the focus area (figs. 1 and 2) with density of about 13 logs per square mile. Coarse-grained sediments comprise about 73 percent of the Magothy aquifer material. Fine-grained and interbedded sediments comprise 8 and 19 percent, respectively. The identified facies intervals were not changed in the conditional simulation. A 10 - $\mathrm{ft}$ vertical sampling interval is used to represent these hard data. The conditional simulation domain (sections shown in fig. 6) uses a regularly spaced grid of data points in 54 columns by 89 rows by 60 layers $(100 \mathrm{ft}$ by $100 \mathrm{ft}$ by $10 \mathrm{ft}$ ); these data points overlap the focus zone of fine MODFLOW model discretization (figs. 1 and 5).

A matrix of facies vertical transiograms may be used to represent the probability of transitioning from one facies to another within a Markov chain. For example, as the vertical distance increases away from a fine-grained facies, the probability increases that one would encounter a coarse-grained facies. Furthermore, the highest probability lies in transitioning into a coarse-grained facies, no matter which facies one starts at. Discrete probabilities were computed every $2 \mathrm{ft}$ vertically using 5-ft moving intervals over a lag range of 0 to $30 \mathrm{ft}$ and are shown as points (fig. 7). To extend transition probabilities from borehole data throughout the conditional simulation domain, it is necessary to construct continuous transition probability models (shown as lines in fig. 7). Although the transiogram matrix defines vertical transition probabilities, it is also necessary to define horizontal transition probabilities. To do this, a 1:60 ratio of vertical to horizontal transition probability was applied using the embedded transition probability method (Carle, 1999) following Misut (2014). Resultant conditional realizations 1 and 2 are displayed (fig. 8) along sections $A-A^{\prime}$ and $B-B^{\prime}$ (fig. 2) and show representative differences between realizations. Realization 1 is also shown as a block diagram within the regional flow model (fig. 9). Horizontal transitioning is isotropic and honors the data from the borings and wells.
Realizations differ slightly because of the probabilistic nature of the realization method, which generates randomized realizations. Nine equiprobable realizations were performed as a preliminary analysis of the role of heterogeneity on plume capture. Nine realizations are a tractable sample population, and the results demonstrate the influence of the distribution of fine-grained facies on plume transport. All realizations matched observed data and facies interpretations given in Tetra Tech (2012a).

\section{Model Stresses and Recharge}

Stresses applied as boundary conditions within the MODFLOW model include pumping wells, using the MNW2 multinode well package (Konikow and others, 2009); recharge to the water table, using the $\mathrm{RCH}$ package embedded within MODFLOW-2005 (Harbaugh, 2005); streams, using the DRN package embedded within MODFLOW-2005; and flowthrough at artificial model boundaries, using the GHB package embedded within MODFLOW-2005. Pumpage data compiled by the NYSDEC, which included public supply, remedial, and golf-course pumpage, were averaged from 2004 to 2007 to represent steady-state postdevelopment conditions (Arcadis CE, Inc., 2010; Misut, 2014). The averages for 2004 to 2007 were applied in the regional model area, with averages of NYSDEC data for 1980 to 2014 applied within the focus area for production wells SFWD6150, SFWD8664, SFWD8665, ANY8480, and ANY9338 (differences listed in table 2). Representation of the variation in pumpage on a seasonal basis was beyond the scope of this study.

Sources of recharge simulated in the MODFLOW model are shown in comparison with other water budget terms in table 3. Recharge from precipitation accounted for spatial and temporal variations in precipitation, permeability of surficial hydrogeologic units, land-cover characteristics, and discharge of domestic and industrial wastewater. Annual average precipitation is about 42 inches (Miller and Fredrick, 1969). Under predevelopment conditions, about 50 percent of the precipitation reached the water table, mainly during the nongrowing season (McClymonds and Franke, 1972; Seaburn and Aronson, 1974). Under present conditions, recharge is mainly from infiltration of precipitation through unpaved areas, and infiltration through recharge basins. At the southern boundary of the model, stormwater runoff is routed into the headwaters of south-flowing stream channels, reducing the recharge basin contribution. Integrated over the regional model area, the present conditions recharge rate is about 25 inches per year (equivalent to $6,555,300$ cubic feet per day $\left[\mathrm{ft}^{3} / \mathrm{d}\right]$ applied to the regional model area).

\section{Steady-State Flow Model Results}

The simulated water balance (table 3) indicates that water mainly enters as water table recharge while water mainly exits as either well pumpage or lateral discharge across southern model boundaries. Simulated steady-state flow fields are generally oriented from northwest to southeast with zones of 


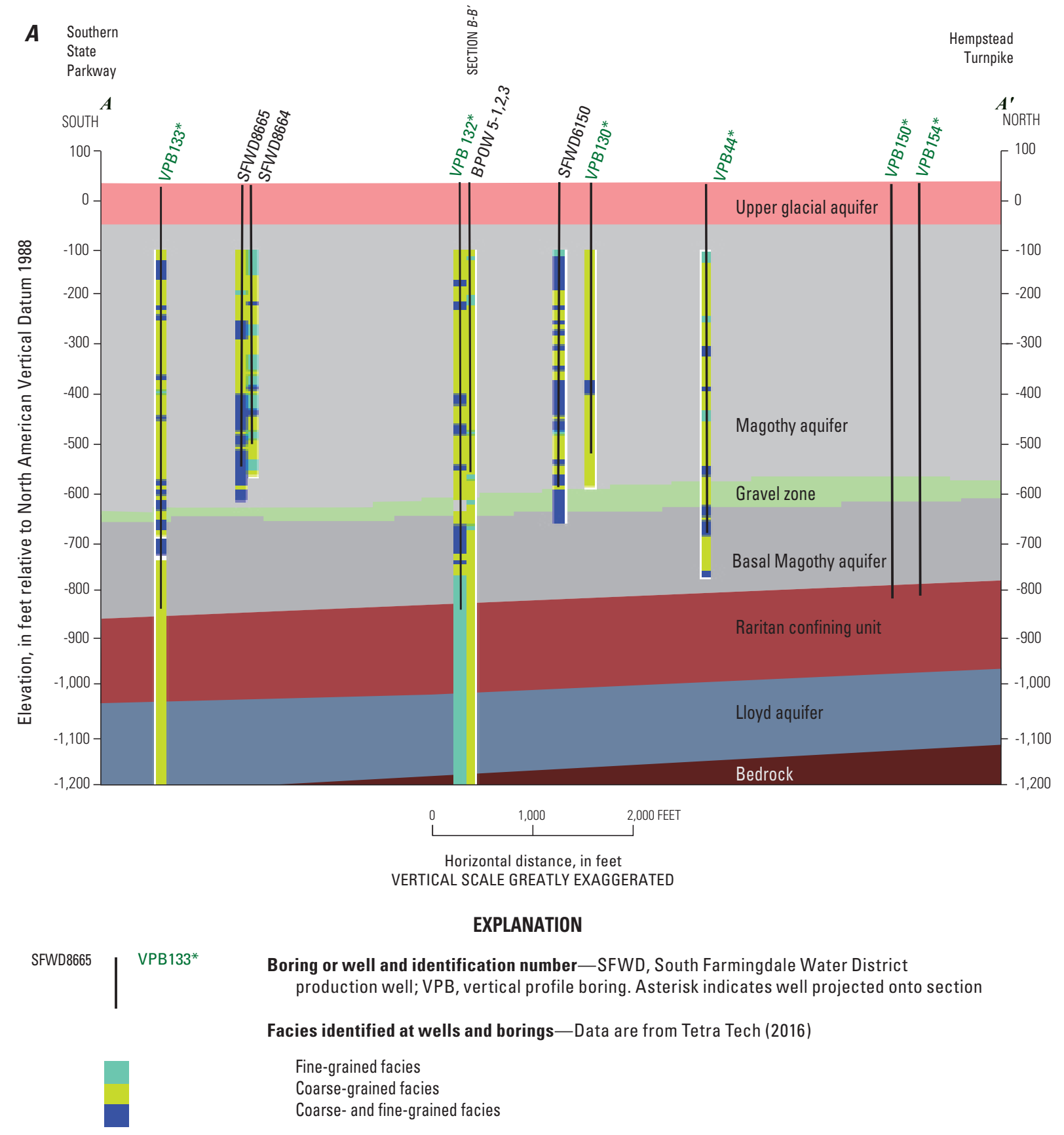

Figure 6. Distribution of coarse-grained, fine-grained, and interbedded facies identified in borings and wells along sections $A, A-A^{\prime}$ and $B, B-B^{\prime}$ used in conditional simulation of Magothy aquifer heterogeneity at Bethpage, New York. Location of sections shown on figure 2. 


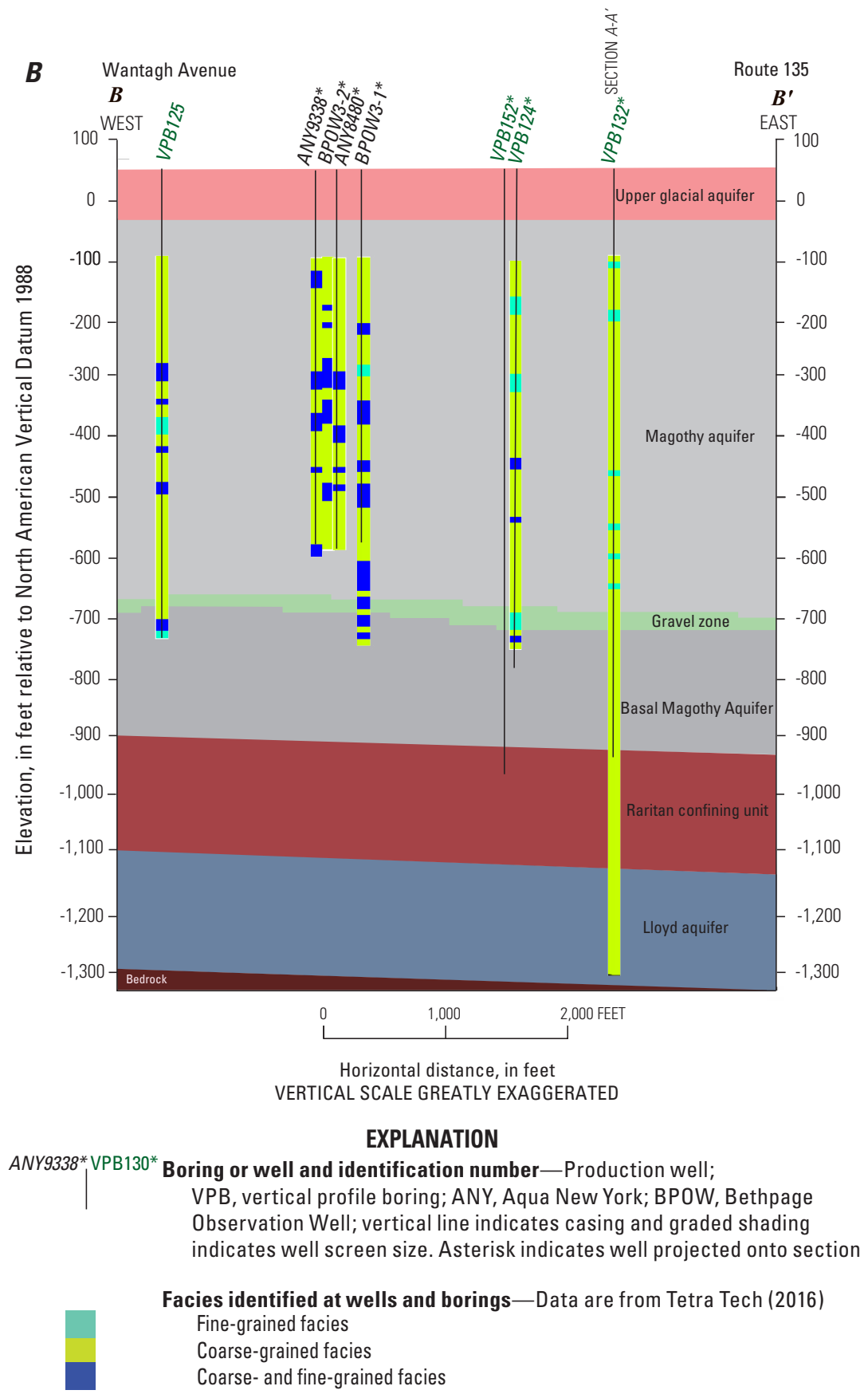

Figure 6. Distribution of coarse-grained, fine-grained, and interbedded facies identified in borings and wells along sections $A, A-A^{\prime}$ and $B, B-B^{\prime}$ used in conditional simulation of Magothy aquifer heterogeneity at Bethpage, New York. Location of sections shown on figure 2.-Continued 


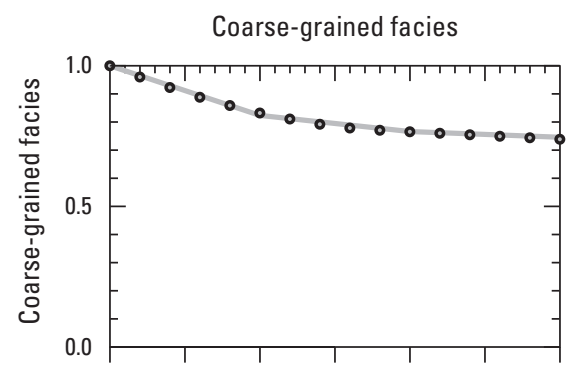

Coarse- and fine-grained facies
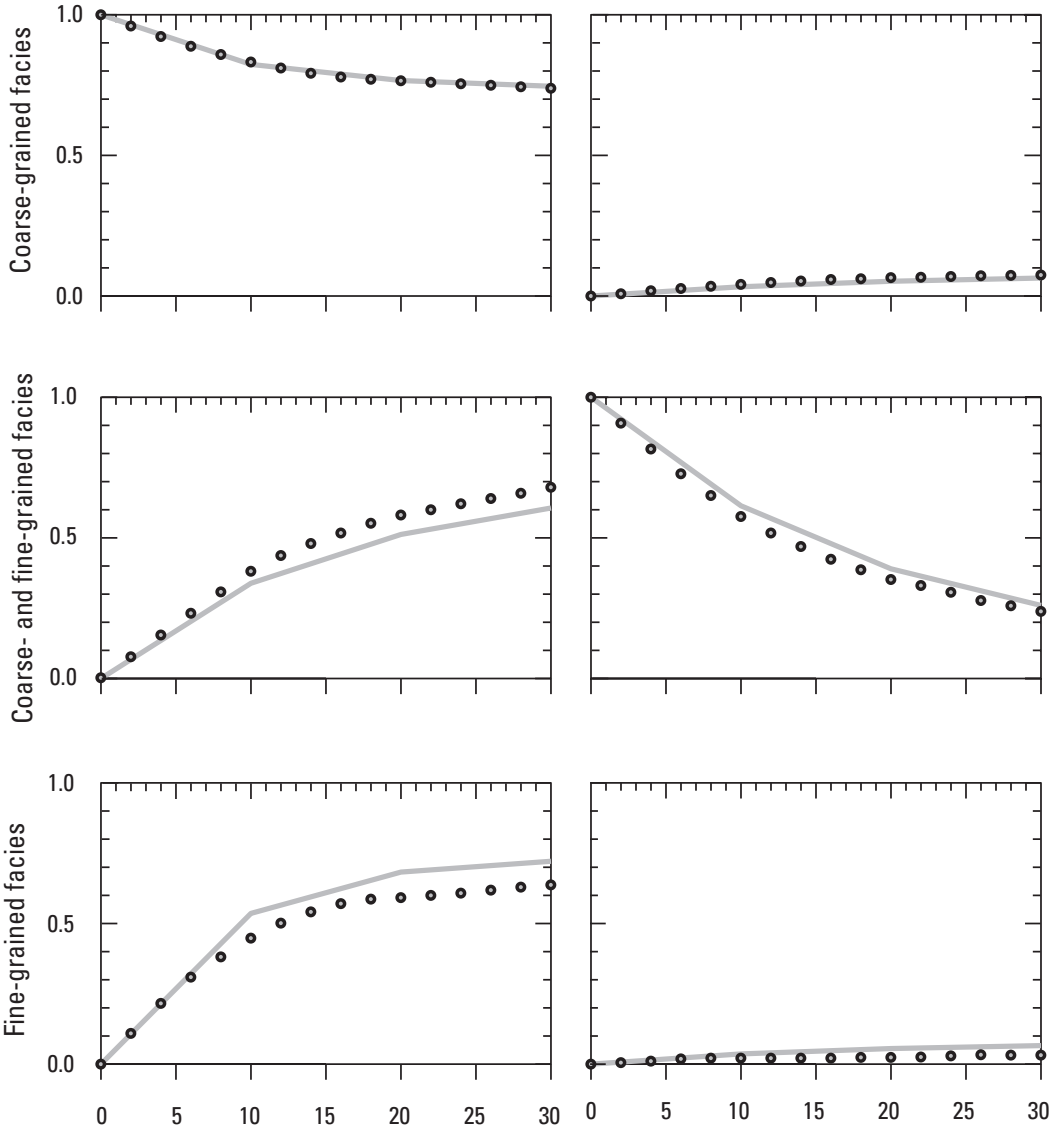

Lag distance, in feet

\section{EXPLANATION}

- Discrete value of probability at lag distance

Continuous model of transition probability at lag distance
Fine-grained facies
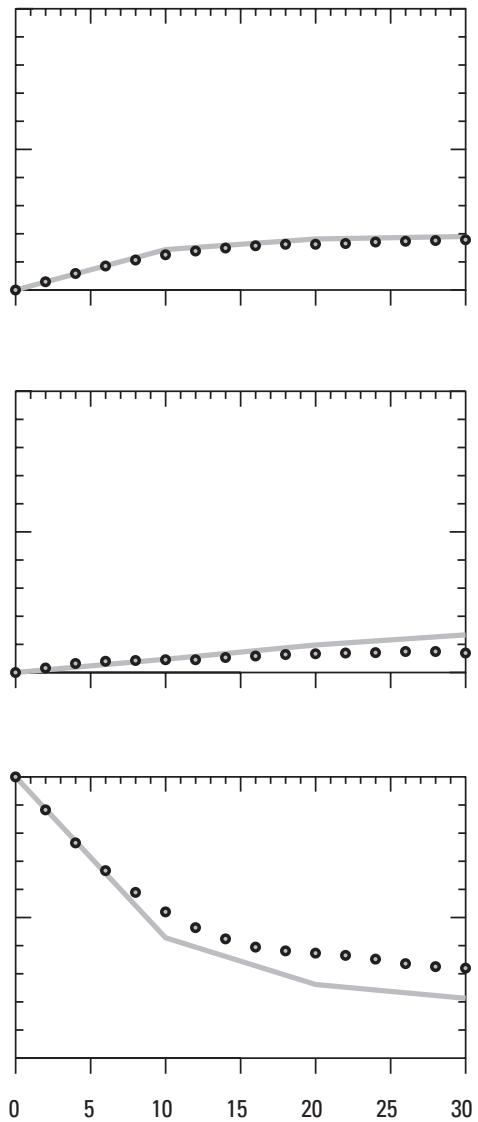

from 2 to 30 feet.

Table 2. Difference in pumping rates between Misut (2014) and present [steady-state] conditions (1980-2014) models, Bethpage, New York.

[ft³/d, cubic foot per day; ft, foot; NAVD 88, North American Vertical Datum of 1988; NA, not available]

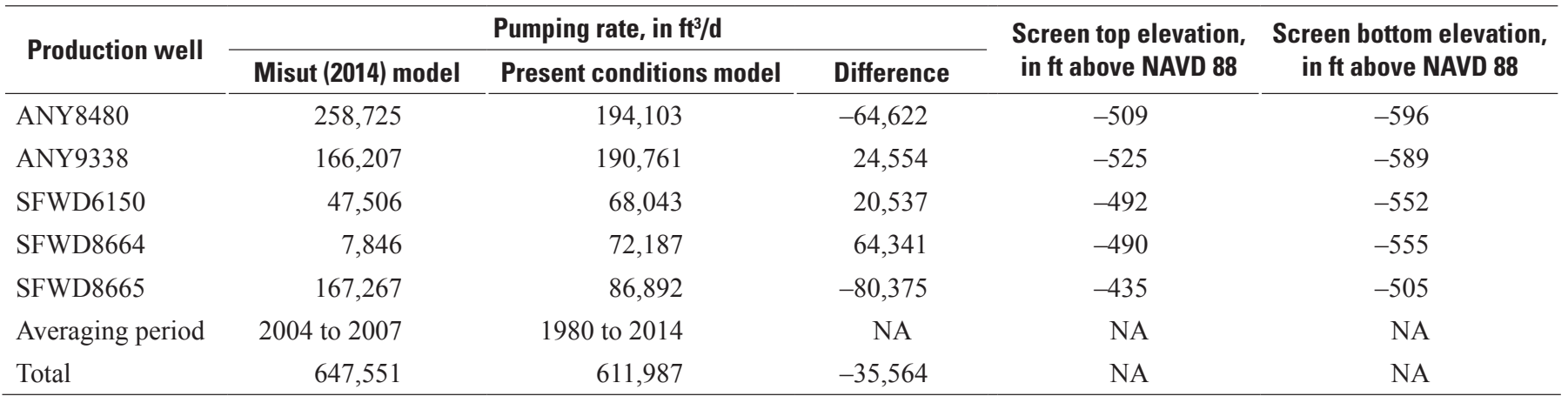


Table 3. Regional model water balance, Bethpage, New York.

\begin{tabular}{|c|c|}
\hline Variable & $\begin{array}{c}\text { Water balance, } \\
\text { in cubic feet per day }\end{array}$ \\
\hline \multicolumn{2}{|c|}{ Inflow } \\
\hline Constant head & 557,312 \\
\hline Specified recharge basins & 878,625 \\
\hline Recharge from precipitation & $6,555,300$ \\
\hline Total & $7,991,237$ \\
\hline \multicolumn{2}{|c|}{ Outflow } \\
\hline Constant head & $3,434,748$ \\
\hline Drains & 740,274 \\
\hline Wells & $3,816,283$ \\
\hline Total & $7,991,305$ \\
\hline
\end{tabular}

convergence at pumping wells and refraction due to the presence of confining beds. There is also a downward component to the simulated flow because of the entry of groundwater recharge from precipitation. The simulated downward component mainly occurs in the northern part of the model, which is just south of a regional flow divide between waters that ultimately discharge to either the northern or southern shores of Long Island (fig. 1, inset). Model layer 42 is a 10-ft thick horizontal layer located about $500 \mathrm{ft}$ below sea level, which is nearby pumping well screens and cones of depression (figs. 10 and 11).

\section{Model Calibration and Sensitivity Analysis}

Hydraulic conductivity and recharge parameters were adjusted through automated and manual methods based on water-level and streamflow data observations. The automated calibration software UCODE_2005 (Poeter and others, 2005) was applied to the present steady-state conditions MODFLOW model (heterogeneity realization 1), and manual adjustment of parameter values was conducted through visual target matching (trial-and-error). After calibration, the steady-state model was used to delineate ZOCs. The calibration water-level data (locations shown in fig. 12) were collected by personnel from Resolution Consultants and USGS in 2015 to 2016 (Resolution Consultants, written commun., 2016) and assumed to represent present steady-state conditions. Use of observations to approximate present steady-state conditions may be evaluated by long-term hydrographs of USGS-collected data. Figure 13 is a hydrograph of observation well N8214 collected by USGS from 1970 to 2016, with the average 2015 water level used for present conditions steady state model calibration. Waterlevel fluctuations in well N8214 and others like it around Long Island are discussed in detail in Busciolano (2005) and Misut (2011). An influence on water-level changes is the large-scale Nassau County sewering project of the 1980s. 2006 was the beginning of a relatively stable condition continuing to about
2015 after which a dryer-than-normal period was entered. As indicated in figure 13, the average water level of 2015 is similar to the average from 1970 to 2016.

Streamflow data used in calibration (gaging station locations shown in figure 4; data available at U.S. Geological Survey, 2017c) was averaged from 1980 to 2008 by Rozell (2010) to represent present condition average flow rates. Percent of total base flow discharge to streams (fig. 14) trended downward from the 1960 s to 1980 because of urbanization but appears to have stabilized (Rozell, 2010) through the present [2017]. The large-scale sewering project of the 1980s likely resulted in decreased streamflow; however, because the overall period 1980 to 2008 includes significant periods of aboveaverage rainfall, groundwater measurements and base flow discharges represent a long-term present condition. Mean total discharge at gages from 1980 to 2008 for the model stream channels are as follows: Massapequa Creek, 6.7 cubic feet per second $\left(\mathrm{ft}^{3} / \mathrm{s}\right)$, and Bellmore Creek, $5.01 \mathrm{ft}^{3} / \mathrm{s}$. Estimated base flows corresponding to the area of model drain boundary conditions (fig. 4) for Massapequa and Bellmore gages are 340,000 and 336,000 $\mathrm{ft}^{3} / \mathrm{d}$ (Misut, 2014), respectively, which may be compared with total simulated base flow of $740,274 \mathrm{ft}^{3} / \mathrm{d}$ (table 3).

During calibration and parameter estimation, horizontal hydraulic conductivity $(\mathrm{Kx})$, vertical hydraulic conductivity $(\mathrm{Kz})$, and recharge parameters were initially set to previous model values of (Misut, 2014) and allowed to vary within the ranges given in table 6. UCODE_2005 utilized the sum of squared residuals (simulated minus observed) for its objective function, with reduction in the function corresponding to better match of simulated with observed composite scaled sensitivity (CSS) was used to compare the amount of information provided by different types of parameters, with model simulation results more sensitive to parameters with large composite scaled sensitivity. A composite scaled sensitivity analysis is available as part of the report model archive (Misut, 2017).

According to the composite scaled sensitivity (fig. 15), the model results are most sensitive to recharge, Magothy aquifer hydraulic conductivity anisotropy ratio $\mathrm{Kx}: \mathrm{Kz}$, and upper glacial aquifer Kx parameters (fig. 15). Model results are least sensitive to Lloyd aquifer and Raritan confining unit parameters. The Lower Magothy gravel zone Kx was moderately sensitive, whereas the gravel zone $\mathrm{Kz}$ was insensitive. In general, sensitivity of low-permeability $\mathrm{Kx}$ and $\mathrm{Kz}$ parameters is low because of the lack of calibration targets within these units (observation wells are typically screened in the high-permeability units). The confidence intervals of the fine-grained facies parameter estimates are relatively large, indicating that it is not possible to confidently estimate these parameters without more observational data. Nevertheless, these parameters may be adjusted within allowed ranges to optimize model fit. A high degree of correlation existed between the following parameter pairs: Raritan confining unit $\mathrm{Kx}$ with outer Magothy aquifer $\mathrm{Kx}$, upper glacial aquifer $\mathrm{Kz}$ with unconfined Magothy aquifer Kz, and the background recharge rate with the recharge basins adjustment factor 


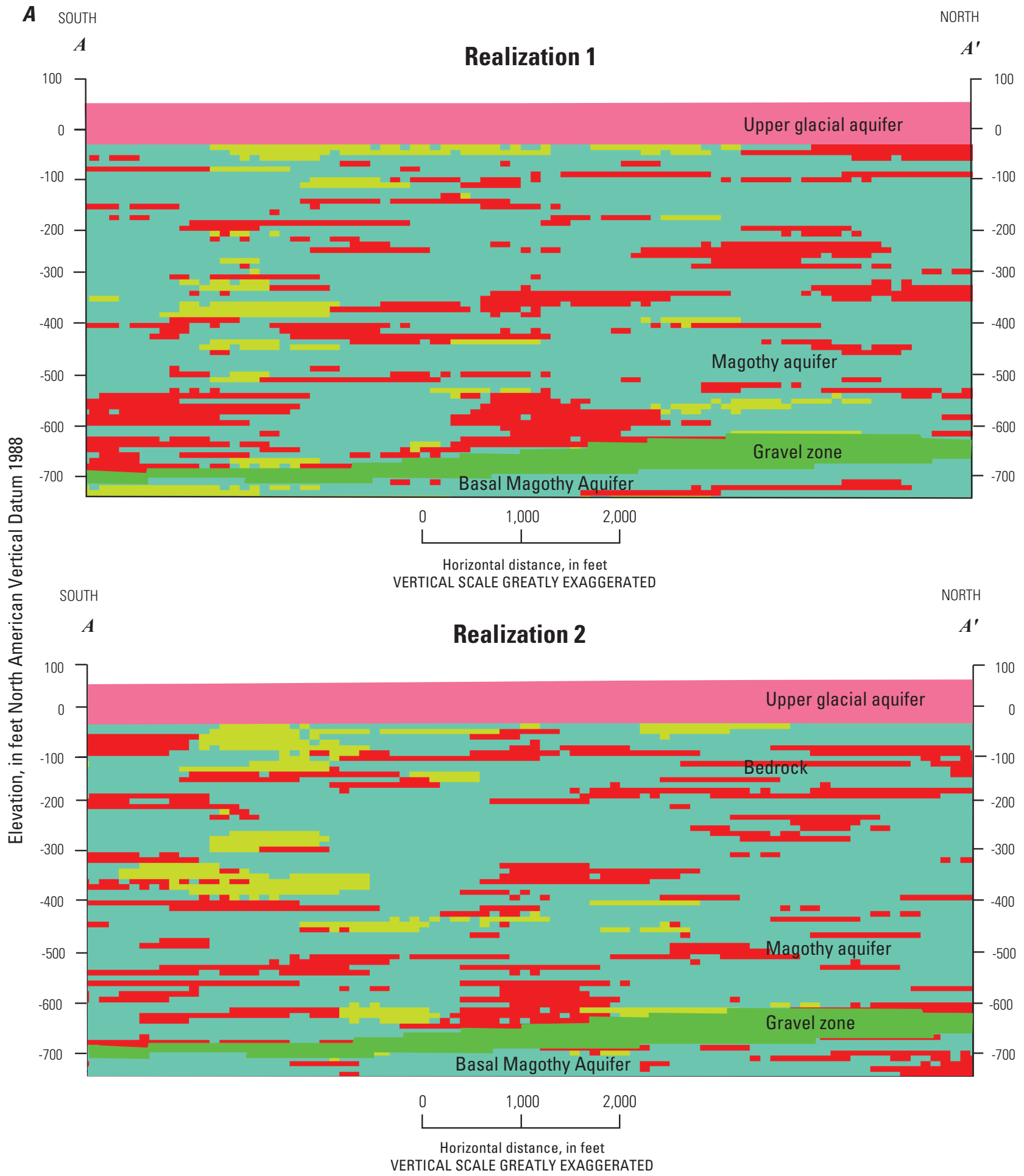

\section{EXPLANATION}

\section{Fine-grained facies}

Coarse-grained facies

Coarse- and fine-grained facies

Gravel zone

Figure 8. Conditional realizations 1 and 2 of Magothy aquifer at Bethpage, New York, heterogeneity along cross sections $A, A-A^{\prime}$ and $B, B-B^{\prime}$. Location of section shown on figure 2 . 


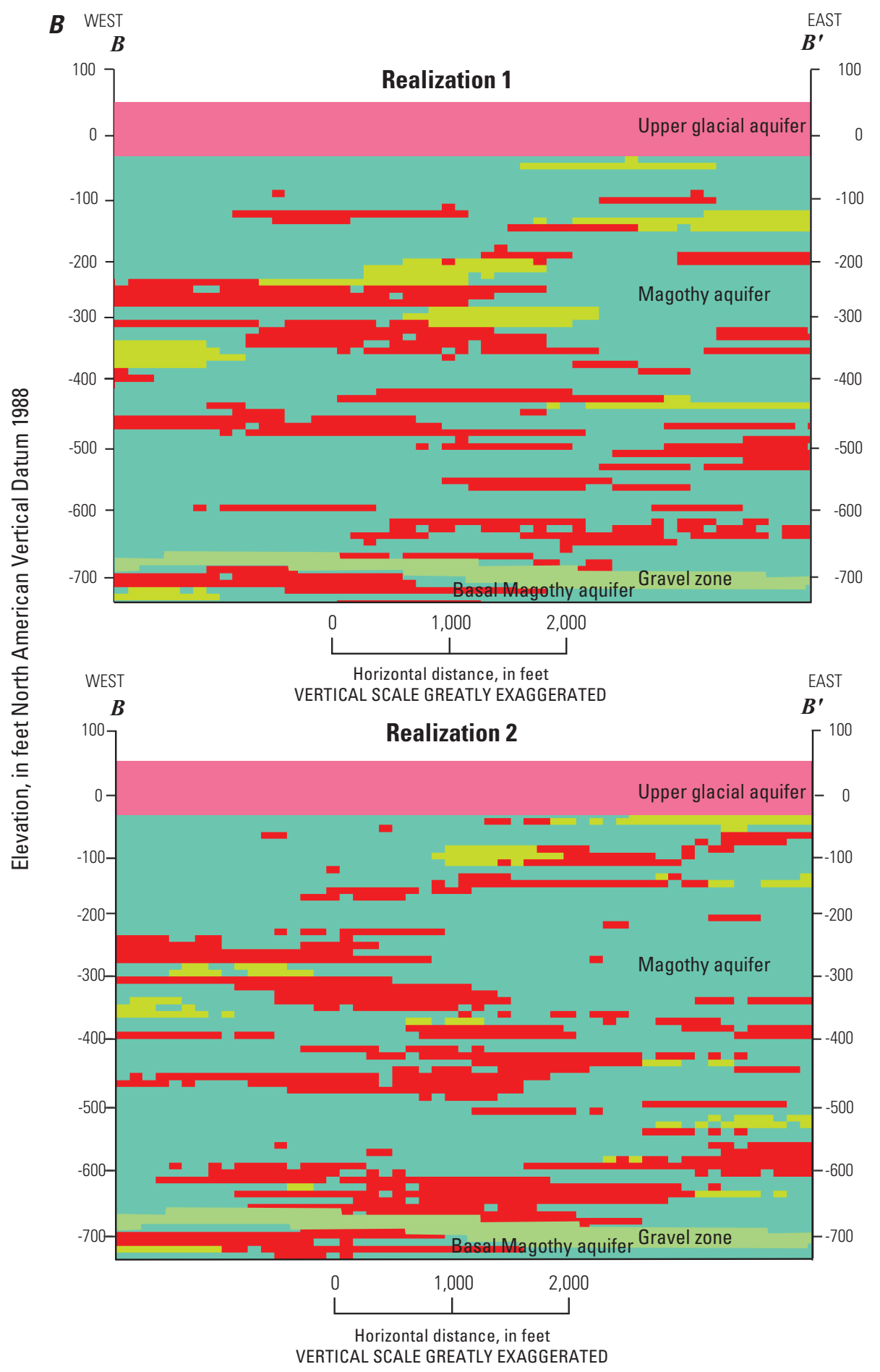

EXPLANATION

Fine-grained facies

Coarse-grained facies

Coarse- and fine-grained facies

Gravel zone

Figure 8. Conditional realizations 1 and 2 of Magothy aquifer at Bethpage, New York, heterogeneity along cross sections $A, A-A^{\prime}$ and $B, B-B^{\prime}$. Location of section shown on figure 2.-Continued 


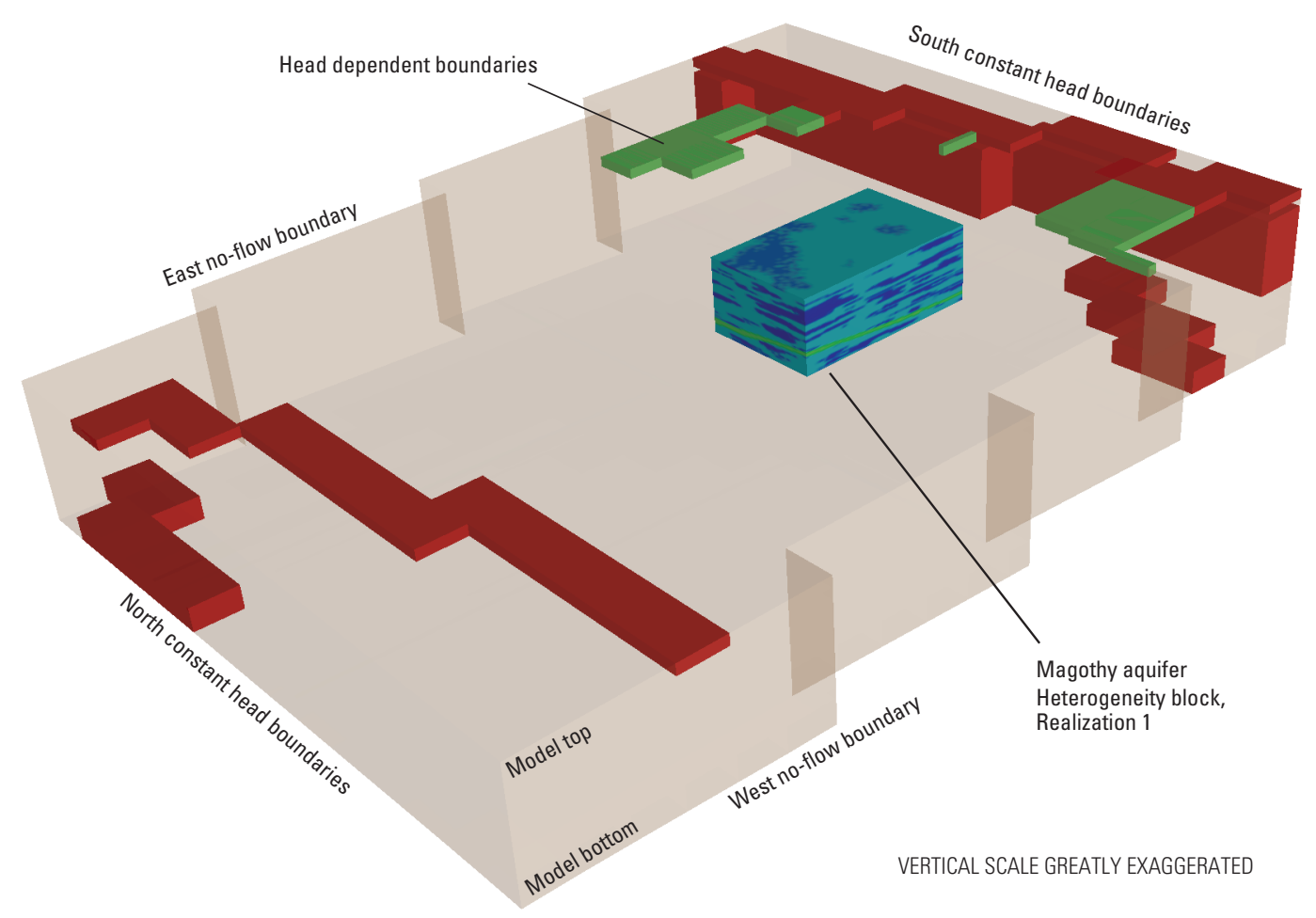

\section{EXPLANATION}

Facies of heterogeneity block

Coarse-grained

Fine-grained and interbedded coarse- and fine- grained

Gravel zone

Figure 9. Conditional realization 1 within regional flow model with boundary conditions and other features in Bethpage, New York.

(factor increases background recharge rate where recharge basins are present). The drain conductance parameter (limits amount of simulated flow for a given hydraulic gradient) was also correlated with both the background recharge rate and the recharge basins adjustment factor.

Final parameter values are somewhat different than those used in the Misut (2014) model. This may be attributed to the following factors: the model grids have different rotations, different cell sizes, and different inactive areas; and the calibration targets are measured during different hydrologic conditions. Most of the target locations are also different due to the shifting of the local focus area from the GM38 water treatment plant (Misut, 2014) to the southwestern wellfields of the South Farmingdale water supply district and the leading edge of the OU2 plume.

The final fit of the water levels simulated by the calibrated steady-state model with heterogeneity realization 1 to observed water levels in the target wells may be assessed quantitatively with table 4 and figure $15 \mathrm{~A}$. The mean residual (observed minus simulated) was $0.32 \mathrm{ft}$, with 25 residuals greater than zero and 17 residuals less than zero (table 4). The sum of squared water level residuals was 367 and the root mean square error was $2.65 \mathrm{ft}$. These statistics are similar for other heterogeneity realizations; for example, the root mean square error associated with heterogeneity realization 2 was $2.57 \mathrm{ft}$.

A greater sensitivity to heterogeneity realization may be expected for simulated particle pathway shapes than for water-level response, because particles take significantly more time to travel around fine-grained bed obstacles than the very short time required for water pressure equalization. Evaluating the sensitivity of the computed model responses to changes in parameter values that reflect plausible parameter uncertainty helps to assess the model reliability. 
Table 4. Observed minus simulated residuals of calibrated present steady-state conditions model, Bethpage, New York.

[Well identification numbers are the MODFLOW well/head observation well identifiers; see appendix 1 for additional well identification information. ft, foot; NGVD 29, National Geodetic Vertical Datum of 1929; MODFLOW, U.S. Geological Survey groundwater-flow modeling software]

\begin{tabular}{|c|c|c|c|}
\hline \multirow{2}{*}{$\begin{array}{l}\text { Well identifi- } \\
\text { cation number }\end{array}$} & \multicolumn{2}{|c|}{ Water level, in ft above NGVD 29} & \multirow{2}{*}{$\begin{array}{l}\text { Residual, } \\
\text { in ft }\end{array}$} \\
\hline & Observed & Simulated & \\
\hline bpow_6_1 & 23.93 & 27.14645 & -3.21645 \\
\hline bpow15 & 44.13 & 44.41131 & -0.28131 \\
\hline bpow16 & 44.05 & 44.02892 & 0.021084 \\
\hline bpow23 & 22.57 & 33.59109 & -11.0211 \\
\hline bpow33 & 36.97 & 34.34173 & 2.628266 \\
\hline bpow34 & 37.11 & 35.29956 & 1.810437 \\
\hline bpow5_1 & 33.89 & 32.79659 & 1.093407 \\
\hline bpow5_4 & 29.16 & 25.97721 & 3.182787 \\
\hline bpow5_5 & 30.64 & 33.33637 & -2.69637 \\
\hline bpow5_6 & 29.83 & 27.49847 & 2.331527 \\
\hline bpow52 & 33.71 & 31.60814 & 2.101862 \\
\hline bpow53 & 33.63 & 31.83279 & 1.797205 \\
\hline bpow6_2 & 23.53 & 26.77075 & -3.24075 \\
\hline bpow6_3 & 24.74 & 27.77789 & -3.03789 \\
\hline bpow6_4 & 25.5 & 27.9715 & -2.4715 \\
\hline n12250 & 48.51 & 50.35212 & -1.84212 \\
\hline n1233 & 65.53 & 64.32316 & 1.206836 \\
\hline n1259 & 50.19 & 52.10994 & -1.91994 \\
\hline n7397 & 66.53 & 73.47295 & -6.94295 \\
\hline n8214 & 24.67 & 27.76574 & -3.09574 \\
\hline re103d1 & 54.75 & 53.03917 & 1.71083 \\
\hline re $103 \mathrm{~d} 2$ & 54.71 & 52.7635 & 1.946501 \\
\hline re $103 \mathrm{~d} 3$ & 54.34 & 52.61903 & 1.720971 \\
\hline re $104 d 2$ & 52.2 & 49.38167 & 2.818333 \\
\hline re $104 d 3$ & 51.78 & 49.44266 & 2.337337 \\
\hline re105d1 & 51.52 & 47.94436 & 3.575636 \\
\hline re $105 \mathrm{~d} 2$ & 49.57 & 44.75004 & 4.819958 \\
\hline re108d1 & 56.83 & 53.71628 & 3.11372 \\
\hline re $108 \mathrm{~d} 2$ & 56.28 & 53.03022 & 3.249775 \\
\hline re117d1 & 29.4 & 31.96802 & -2.56802 \\
\hline re $117 d 2$ & 30.27 & 31.75955 & -1.48955 \\
\hline re118d1 & 30.84 & 32.77596 & -1.93596 \\
\hline re120d1 & 49.86 & 48.06559 & 1.794406 \\
\hline re $120 \mathrm{~d} 2$ & 50.03 & 47.72542 & 2.304579 \\
\hline re $120 \mathrm{~d} 3$ & 55.06 & 47.45818 & 7.601816 \\
\hline re122d1 & 57.22 & 54.37334 & 2.846662 \\
\hline re $122 \mathrm{~d} 2$ & 56.79 & 53.95444 & 2.835562 \\
\hline re $122 \mathrm{~d} 3$ & 55.86 & 53.56541 & 2.294587 \\
\hline $\mathrm{tt} 101 \mathrm{~d} 1$ & 46.1 & 46.27803 & -0.17803 \\
\hline $\mathrm{tt} 101 \mathrm{~d} 2$ & 46.53 & 45.3542 & 1.175799 \\
\hline $\mathrm{tt} 102 \mathrm{~d} 1$ & 26.79 & 26.82283 & -0.03283 \\
\hline $\mathrm{tt} 102 \mathrm{~d} 2$ & 26.71 & 29.70359 & -2.99359 \\
\hline
\end{tabular}

Table 5. Monitored observation wells in Bethpage, New York.

[Well numbers listed are local well numbers; see appendix 1 for additional well identification. ft, foot; NAVD 88, North American Vertical Datum of 1988]

\begin{tabular}{|c|c|c|}
\hline \multirow{2}{*}{ Well } & \multicolumn{2}{|c|}{ Screen interval, in ft above NAVD 88} \\
\hline & Top & Bottom \\
\hline RE117D2 & -738.00 & -743.00 \\
\hline RE118D1 & -723.00 & -728.00 \\
\hline BPOW6-2 & -713.00 & -718.00 \\
\hline BPOW6-3 & -708.00 & -713.00 \\
\hline RE117D1 & -679.00 & -704.00 \\
\hline TT101D2 & -696.00 & -701.00 \\
\hline BPOW1-6 & -642.94 & -692.94 \\
\hline RE104D3 & -675.00 & -680.00 \\
\hline RE120D3 & -659.00 & -664.00 \\
\hline RE105D2 & -648.00 & -653.00 \\
\hline N8214 & -646.00 & -651.00 \\
\hline RE104D2 & -625.00 & -630.00 \\
\hline RE103D4 & -624.00 & -629.00 \\
\hline RE122D3 & -623.00 & -628.00 \\
\hline BPOW3-4 & -577.56 & -627.56 \\
\hline RE120D2 & -609.00 & -614.00 \\
\hline BPOW5-3 & -563.96 & -603.96 \\
\hline BPOW1-5 & -543.25 & -593.25 \\
\hline RE103D2 & -565.00 & -570.00 \\
\hline BPOW3-3 & -519.36 & -559.36 \\
\hline RE120D1 & -549.00 & -554.00 \\
\hline BPOW5-6 & -543.00 & -548.00 \\
\hline RE108D2 & -540.00 & -545.00 \\
\hline RE103D1 & -534.00 & -539.00 \\
\hline BPOW2-3 & -506.02 & -536.02 \\
\hline TT101D2 & -526.00 & -531.00 \\
\hline BPOW5-2 & -483.68 & -523.68 \\
\hline BPOW6-1 & -508.00 & -513.00 \\
\hline BPOW5-4 & -503.00 & -508.00 \\
\hline BPOW6-4 & -503.00 & -508.00 \\
\hline RE122D2 & -498.00 & -503.00 \\
\hline TT102D1 & -496.00 & -501.00 \\
\hline BPOW5-5 & -463.00 & -488.00 \\
\hline BPOW5-1 & -423.88 & -453.88 \\
\hline RE105D1 & -448.00 & -453.00 \\
\hline RE108D1 & -440.00 & -445.00 \\
\hline RE122D1 & -428.00 & -433.00 \\
\hline N12250 & 27.00 & 22.00 \\
\hline N1259 & 42.50 & 37.50 \\
\hline N1233 & 53.00 & 48.00 \\
\hline N7397 & 59.00 & 54.00 \\
\hline
\end{tabular}




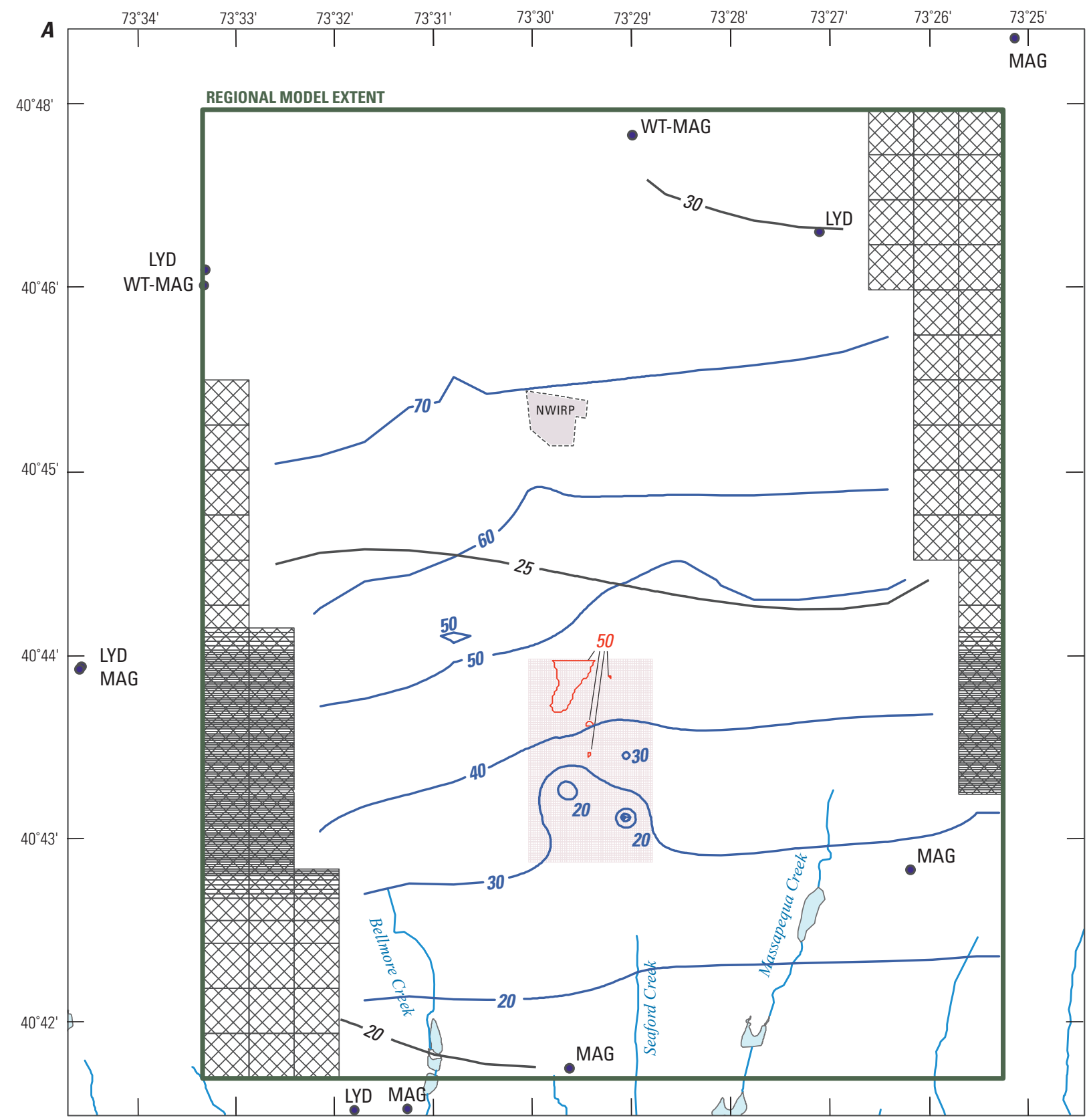

Base from U.S. Geological Survey digital data, 1:24,000

Lambert conformal conic projection, North American Datum 1983

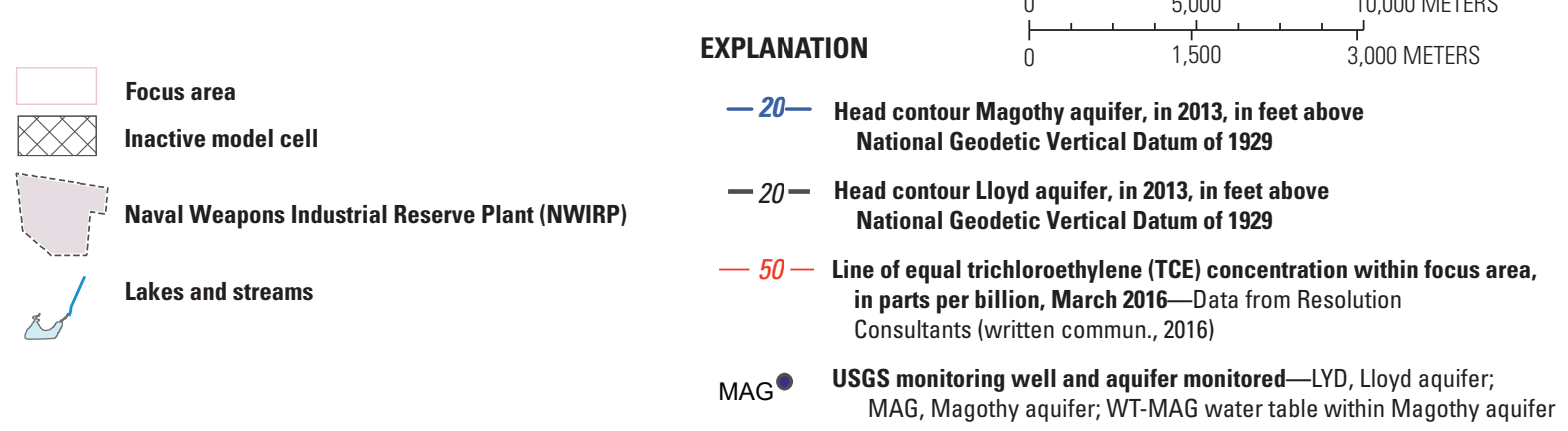

Figure 10. Present conditions steady-state heads and other features in Bethpage, New York, in $A$, regional model and $B$, the focus area using aquifer heterogeneity realization 1. 


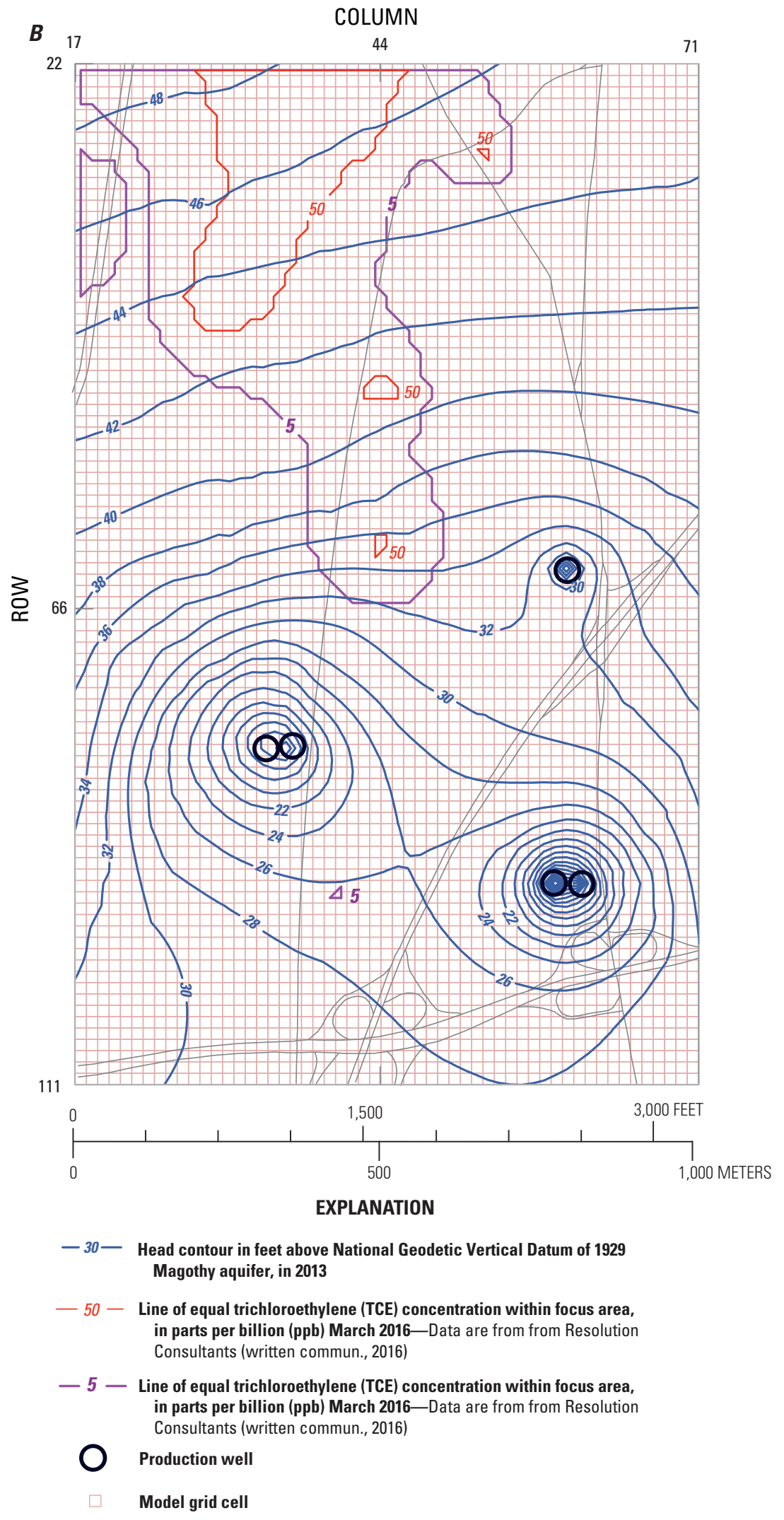

Figure 10. Present conditions steady-state heads and other features in Bethpage, New York, in $A$, regional model and $B$, the focus area using aquifer heterogeneity realization 1.-Continued 

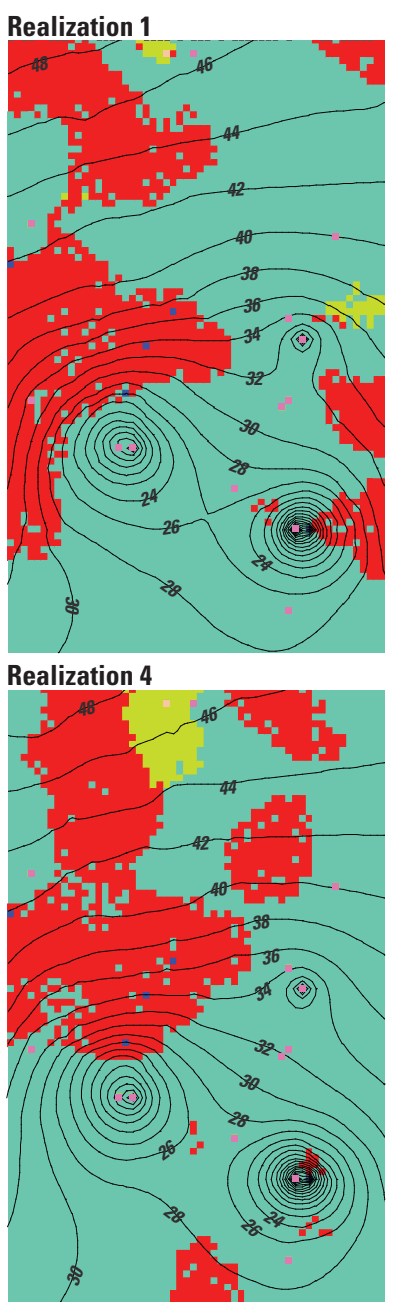

Realization 7

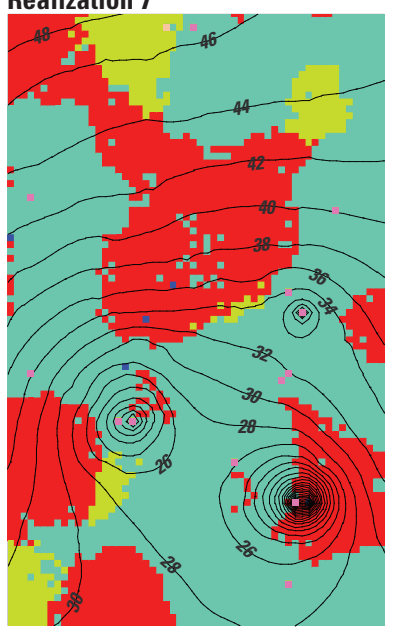

\section{Realization 2}

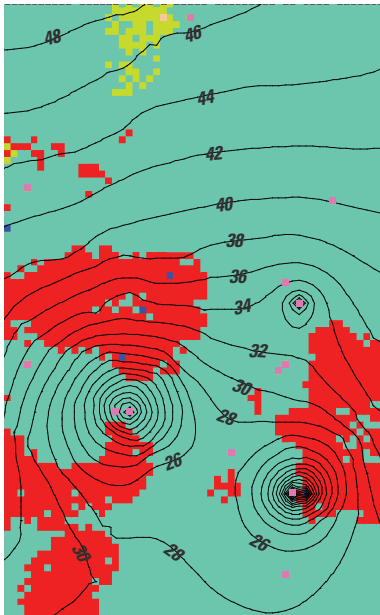

Realization 5

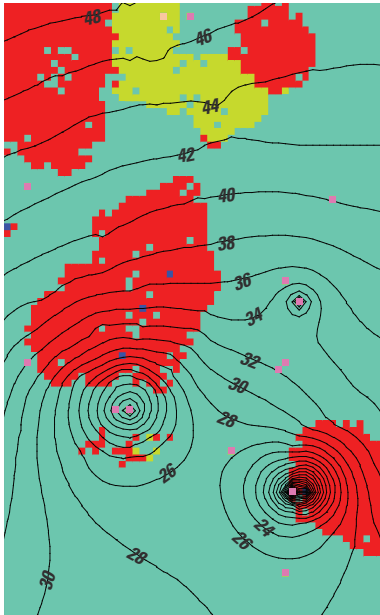

Realization 8

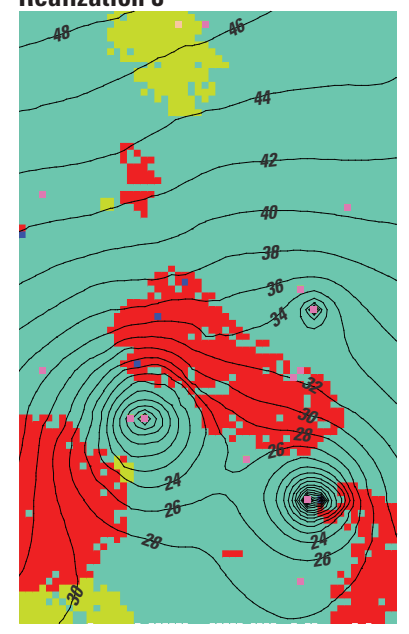

0

2,250

3,000 FEET

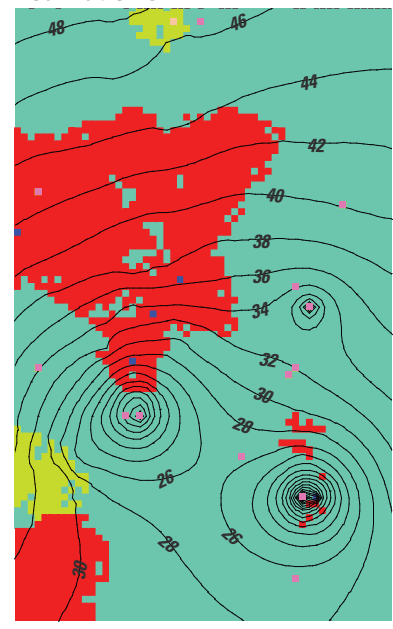

\section{Realization 6}

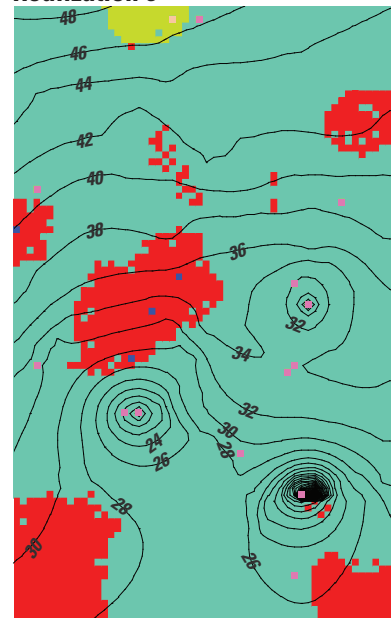

Realization 9

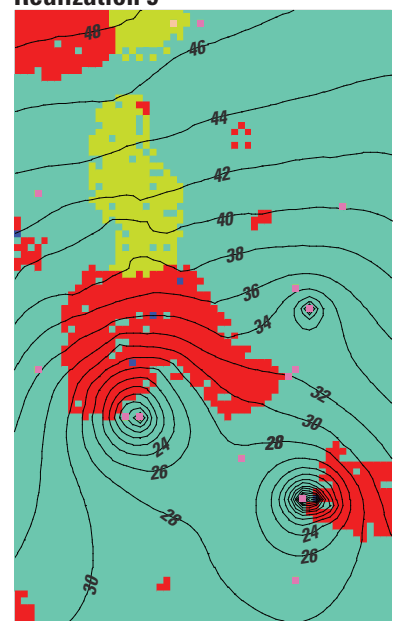

1,000 METER

\section{EXPLANATION}

\section{Modeled facies realizations}

Fine grained horizontal hydraulic conductivity $(\mathrm{Kx})$ is $5 \mathrm{ft} /$ day, vertical hydraulic conductivity $(\mathrm{Kz})$ is $0.009 \mathrm{ft} / \mathrm{day}$

Interbedded horizontal hydraulic conductivity $(\mathrm{Kx})$ is $1.5 \mathrm{ft} /$ day, vertical hydraulic conductivity $(\mathrm{Kz})$ is $0.2 \mathrm{ft} /$ day)

Background Magothy aquifer hydraulic conductivity horizontal $(\mathrm{Kx})$ is $50 \mathrm{ft} /$ day, vertical $(\mathrm{Kz})$ is $1.5 \mathrm{ft} /$ day)

\section{Measured facies realizations}

- Fine grained facies - Hard data

Interbedded facies-Hard data

- Background Magothy facies-Hard data

- 30- Line of equal simulated head in model layer, 2-foot interval, steady-state present conditions-Geodetic Vertical Datum of 1929
Figure 11. Simulated present conditions steady-state heads at model layer 42 ( -500 feet above the North American Vertical Datum of 1988 [NAVD 88]) and heterogeneity realizations 1 through 9 in the focus area in Bethpage, New York. Focus area shown in figure 1. 


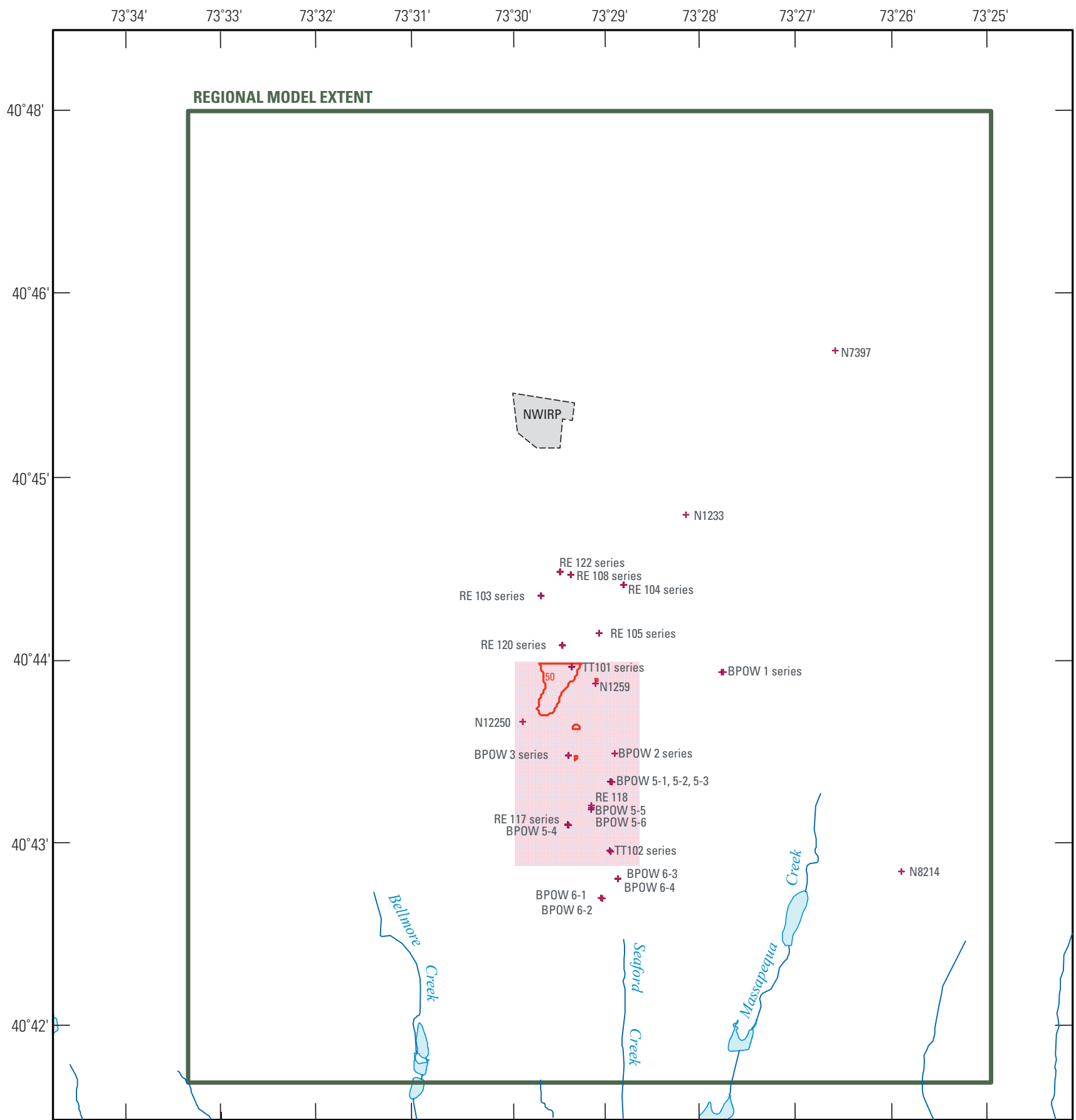

Base from U.S. Geological Survey digital data, 1:24,000 Lambert conformal conic projection, NAD 83

Lakes and streams mapped by New York State Department of Environmental Conservation, 2010

EXPLANATION

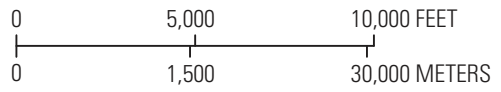

Focus area
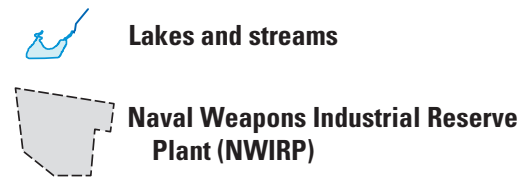

Line of equal trichloroethylene (TCE) concentration within focus area, 50 parts per billion (ppb), March 2016-Data from Resolution Consultants (written commun., 2016)

$\mathrm{N}_{214}{ }^{+} \quad$ Observation well, and identification

Figure 12. Location of observation wells at Bethpage, New York. Observation wells are from Arcadis CE, Inc. (2010). 


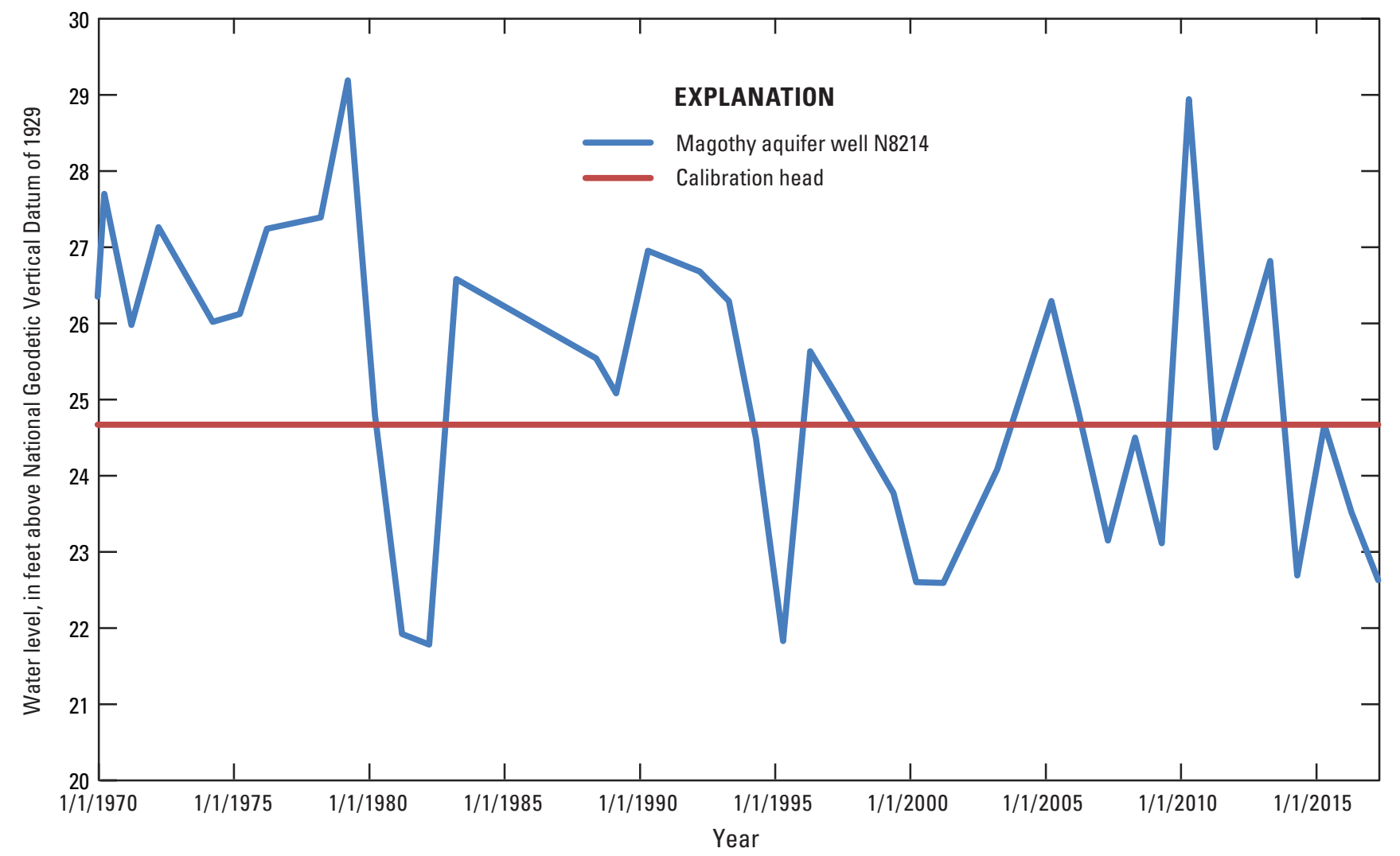

Figure 13. Head time series of U.S. Geological Survey observation well N8214 at Bethpage, New York, from 1970 to 2016 and present-conditions calibration head. Well location shown in figure 12.

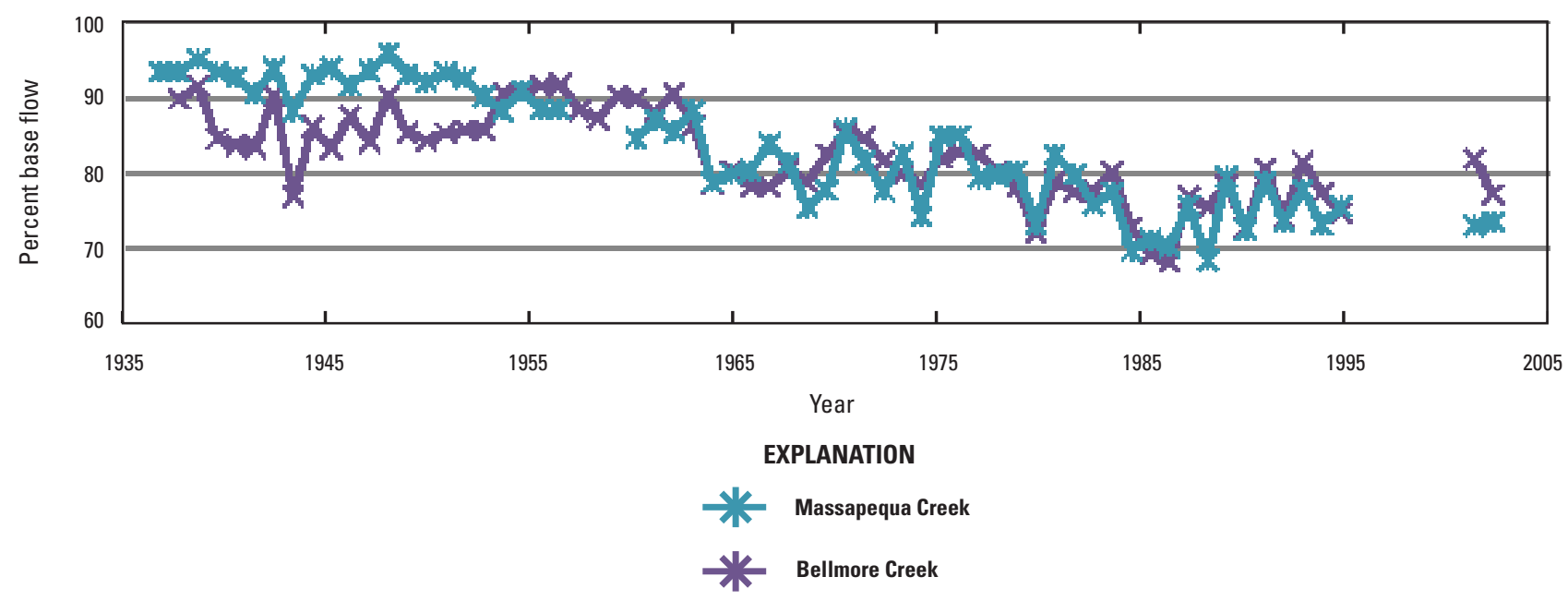

Figure 14. Base flow (contribution of groundwater to streamflow) as a percentage of total flow for Massapequa and Bellmore Creeks, New York. Locations are shown in figure 4. Data are from Rozell (2010). 
A

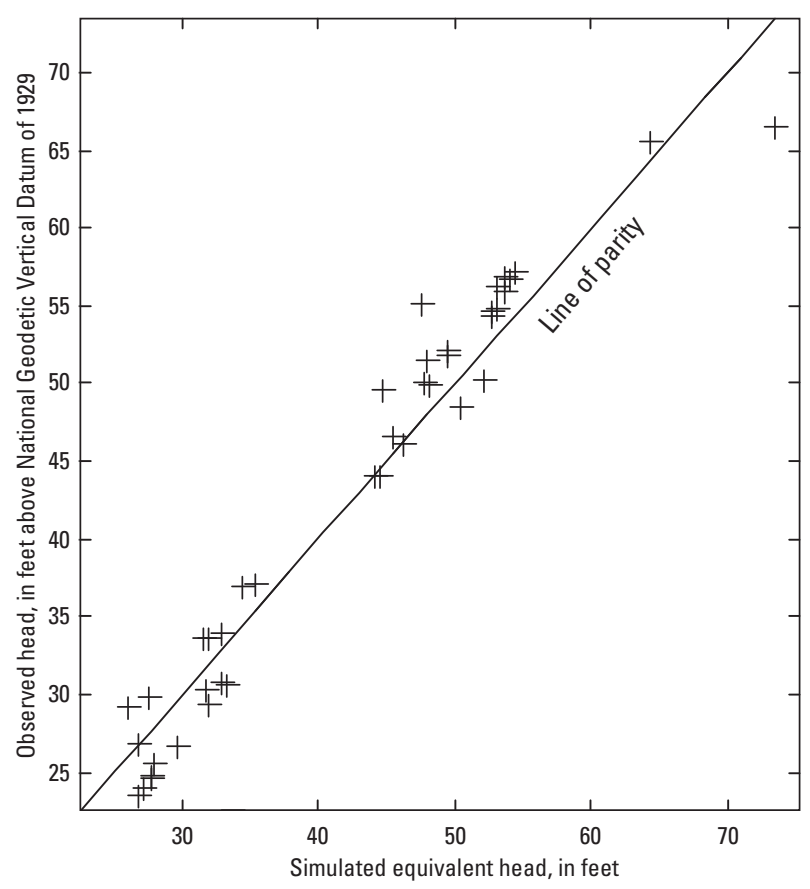

$\boldsymbol{B} \quad$ Composite scaled sensitivity

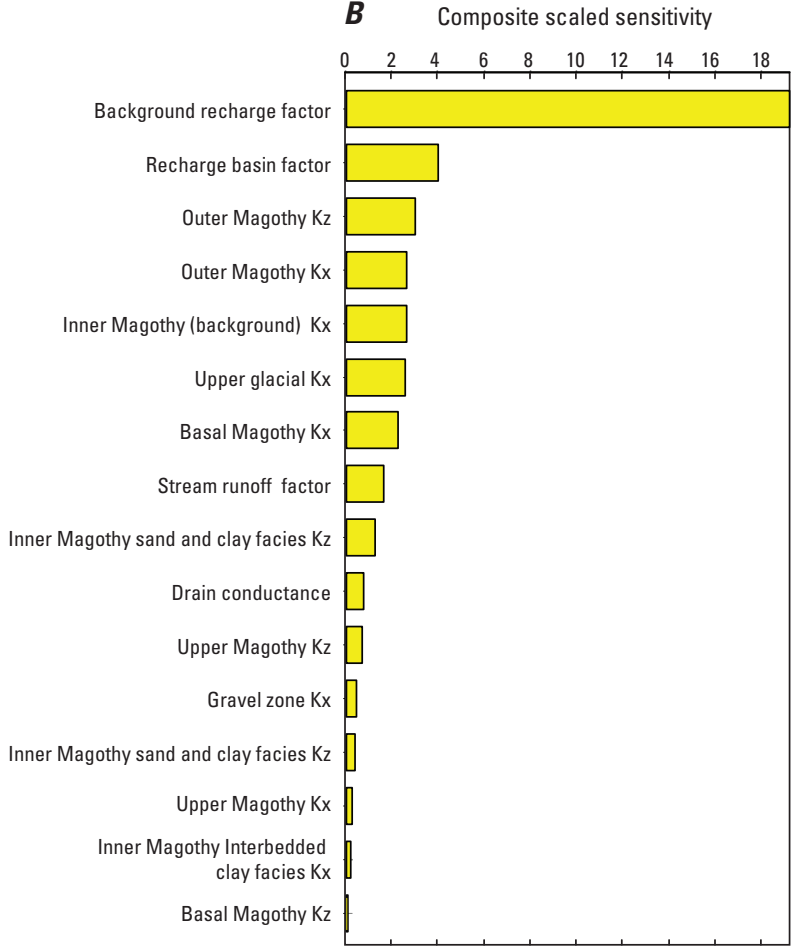

Figure 15. A, Comparison of simulated and observed water levels and $B$, composite scaled sensitivities of most sensitive parameters, corresponding to UCODE_2005 estimation of present steady-state conditions MODFLOW parameters for Bethpage, New York. Kx, horizontal hydraulic conductivity; Kz, vertical hydraulic conductivity.

\section{Archived Model Information}

An archive of the model files used in this report are published in Misut (2018). Steady-state inputs and parameters of MODFLOW and MODPATH models include arrays or matrices of cell-by-cell values, point sets, and scalar values. Arrays include top layer recharge rate, top and bottom model layer altitudes, and most hydraulic conductivities. Point sets include constant-head boundary conditions, well discharges, recharge-basin inflow, stream boundary conditions, and particle release points. Because of a lack of spatial variability, constant values are used for the following inputs: bottom of model layer 1 (set to sea level), porosity, and conductivity of the Raritan formation units. 
Table 6. Initial and final calibrated parameter values of a MODFLOW present steady-state conditions model, as estimated by UCODE_2005, for Bethpage, New York.

[NA, not available]

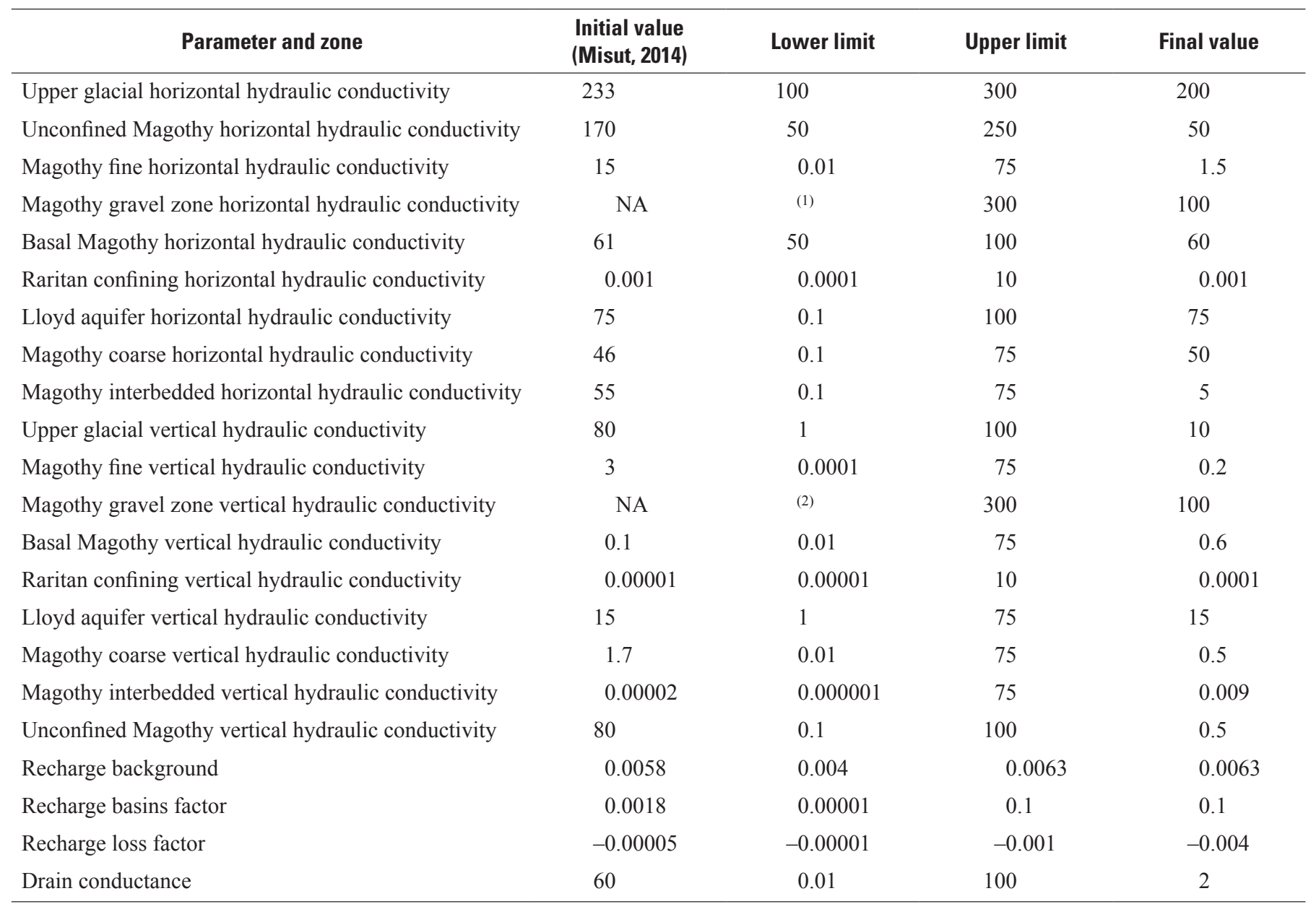

${ }^{1}$ Lower limit is the Magothy coarse horizontal hydraulic conductivity.

${ }^{2}$ Lower limit is the Magothy coarse vertical hydraulic conductivity.

\section{Analysis of Zones of Contribution to Wells}

As discussed by Reilly and Pollock (1993), the term "source of water to wells" has been used in the hydrologic literature in two distinct contexts: a water-budget context and a transport context. The water-budget context addresses the water-budget components affected by water withdrawn from the groundwater system (for example, water withdrawn from a well can cause a net decrease in groundwater discharge to a stream). The transport context represents the plume geometry and the location where the water discharging from a well originally entered the groundwater system (see Franke and others, 1998). The transport context focuses on the flow paths of water to the actual point of discharge. The following transport terms are considered standard terminology for USGS reports: "area contributing recharge" and "zone of contribution"
(ZOC). The USGS does not use the term "capture zone" (as used by Tetra Tech, 2012b), which is a somewhat stronger term suggesting total capture including dispersion, as opposed to partial "contribution" (U.S. Geological Survey, 2003) from MODFLOW-based advection.

Area contributing recharge is defined as the surface area on the boundary of the groundwater system that delineates the location of the water entering the groundwater system that eventually flows to the well (modified from Reilly and Pollock, 1993). This boundary is typically located on the water table; however, depending upon the definition of the groundwater system under investigation, it can be located along any boundary. One boundary that may be used is a plume shell delineation, typically an isoconcentration surface. "ZOC" is defined as the three-dimensional volumetric part of an aquifer through which groundwater flows to a well from the area contributing recharge (modified from Morrissey, 1989). 
The ZOC can be visualized as a three-dimensional stream tube through the aquifer. Typically, these are projected to an areal view or a cross-sectional view. ZOCs may be delineated through backwards tracking of particles that are initiated at wells, and simulated with present conditions steady-state models. In this report, ZOC stream tubes are bounded by the pumping well and one or more of the following: the water table recharge boundary, specified flow boundaries representing recharge basins receiving waters from water treatment plants, and various delineations of the surface boundaries or shells of the plume solid, further described below. ZOCs may also be limited by time; for example, a 5-year ZOC refers to that part of the ZOC that extends from the well to points of particle traveltime not exceeding 5 years. This ZOC relates to the source of water captured by a well within 5 years.

Factors that affect the size and shape of 5-year ZOCs to pumping wells are discussed in the following sections and include those affecting the calibration of the present steadystate conditions model, and porosity. The apparent crossing of ZOCs in plan view projections (fig. 16) may be addressed by limiting the depth interval, by observing the points of pathline intersection on plume shell delineations (fig. 17), and by exploding a schematic diagram to display simultaneous top, front, and side views (fig. 18). In figure 17, the distribution of the points of intersection of backtracked particles with the plume shell may be explained by three-dimensional irregularity of the plume shell and location of particles above or below the shell in its three-dimensional context. In addition, aquifer heterogeneity contributes to the irregular distribution of particle endpoints. Out of 3,100 backward-tracked particles released at well ANY8480 (and allowed to pass through weak sinks), a total of 188 particles intersect the plume, representing about 6 percent of the total particle capture of well ANY8480, and less than 1.5 percent of the total particle $(13,337)$ capture of all wells within the focus area. Of all wells, only well ANY8480 captures water from within the 5-ppb plume in 15 years or less. In figure 18, the traveltime of paths of backtracked particles from well to plume shell intersection (maximum of 5 years traveltime) is shown with pathlines projected onto slice representations of the plume shell along individual rows and columns, indicating the rounded threedimensional shape of the downgradient end of 5-ppb plume shell. The majority of capture pathways, including shortest-intime and longest in distance, are horizontal. However, some pathways are located within the gravel zone of the Magothy aquifer (layers 59 to 62). Because of a slight dip in the gravel zone, particle pathlines within the gravel zone may be slightly curved in sectional view.

\section{Variability in Porosity and Traveltime}

Particle velocity is inversely correlated to porosity. Alternate hypothetical simulations were conducted to demonstrate how particle termination at plume shells is related to porosity and maximum traveltime specification (table 7). The baseline porosity parameter value is 0.25 , in the middle of a range between 0.15 and 0.35 . An alternate model with a significant porosity decrease to 0.15 results in longer particle pathlines of a given maximum traveltime, an increased number of particles intersecting the plume shell, and a greater degree of capture of plume water by production wells. However, throughout the porosity range, in order for wells other than well ANY8480 to show plume capture, the maximum traveltime must also be increased because the sensitivity of results to porosity specification within the range is limited. For the traveltime of 5 years, no wells other than well ANY8480 capture any part of a plume within the range of porosity variation; however, if the traveltime is increased to 10 years, then other wells capture plume water using a decreased porosity value. During long traveltime, low porosity simulations, well ANY8480 remains most likely to capture a small part of the plume, followed by wells ANY9338 and SFWD6150.

Table 7. Comparison of particle endpoints for alternate porosity and maximum traveltime simulations, Bethpage, New York.

[ppb, part per billion]

\begin{tabular}{cccccl}
\hline Porosity & $\begin{array}{c}\text { Maximum } \\
\text { traveltime, } \\
\text { in years }\end{array}$ & $\begin{array}{c}\text { Particles } \\
\text { remaining } \\
\text { active }\end{array}$ & $\begin{array}{c}\text { Plume shell } \\
\text { concentration, } \\
\text { in ppb }\end{array}$ & $\begin{array}{c}\text { Particles } \\
\text { terminated at } \\
\text { plume shell }\end{array}$ & \multicolumn{1}{c}{ Wells capturing plume } \\
\hline 0.25 & 5 & 13,189 & 5 & 188 & $\begin{array}{c}\text { Figure illustration } \\
\text { of endpoints }\end{array}$ \\
0.25 & 10 & 12,861 & 5 & 516 & ANY8480, ANY9338 \\
0.25 & 30 & 11,790 & 5 & 1,587 & ANY8480, ANY9338, SFWD6150, \\
& & & & & SFWD8664, SFWD8665 \\
0.35 & 10 & 12,967 & 5 & 401 & ANY8480 \\
0.15 & 10 & 12,651 & 5 & 726 & ANY8480, ANY9338, SFWD6150 \\
0.15 & 10 & 13,169 & 50 & 208 & ANY8480 \\
0.15 & 30 & 9,165 & 5 & 2,406 & ANY8480, ANY9338, SFWD6150, \\
\end{tabular}




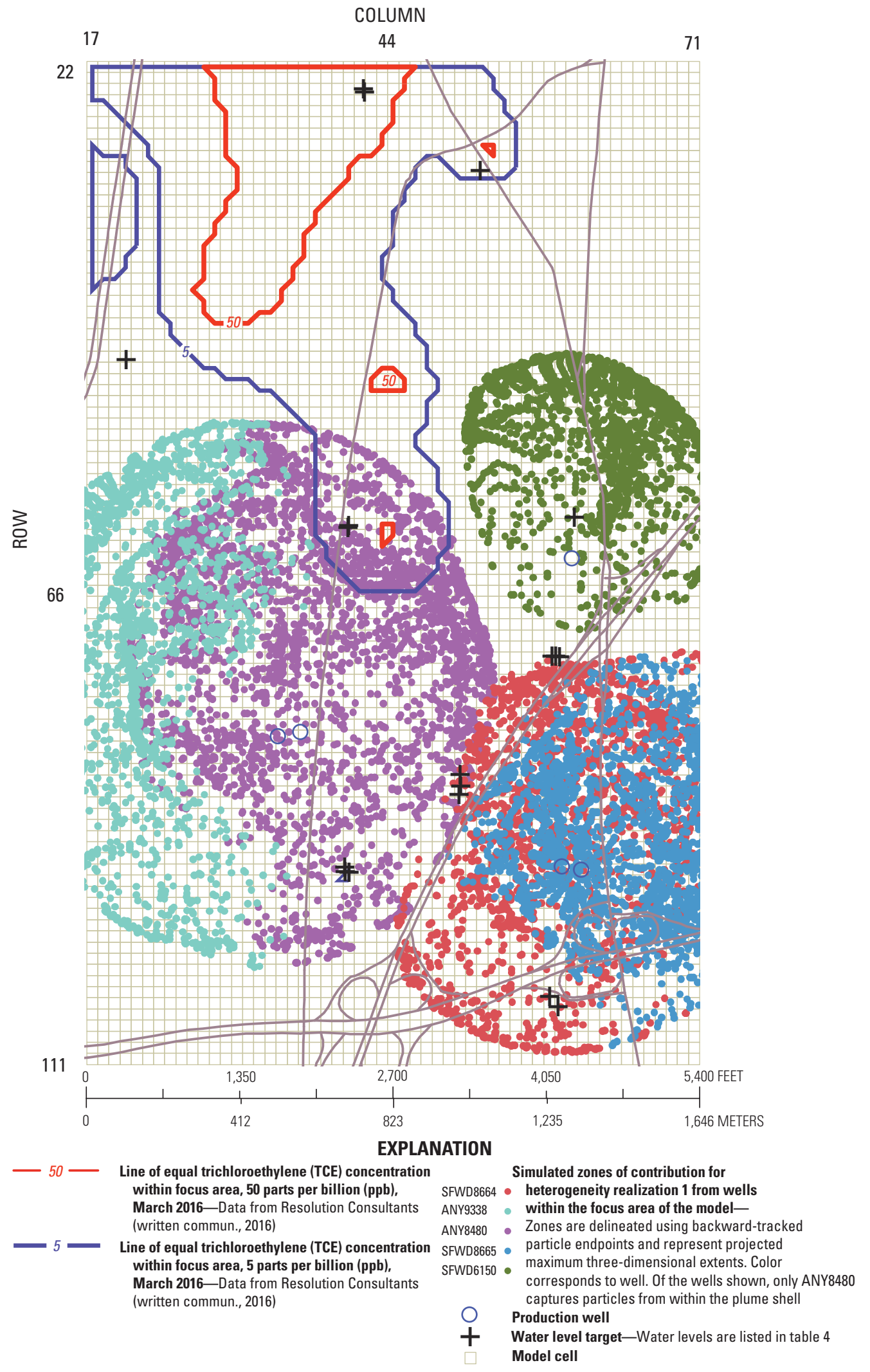

Figure 16. Zones of contribution represented as projections of maximum extent of three-dimensional particle endpoints tracked backward from pumping stresses at South Farmingdale Water District wells SFWD6150, SFWD8664, SFWD8665, and Aqua NY wells ANY8480 and ANY9338 at Bethpage, New York, after 5 years, simulated using present steady-state conditions model realization 1. 


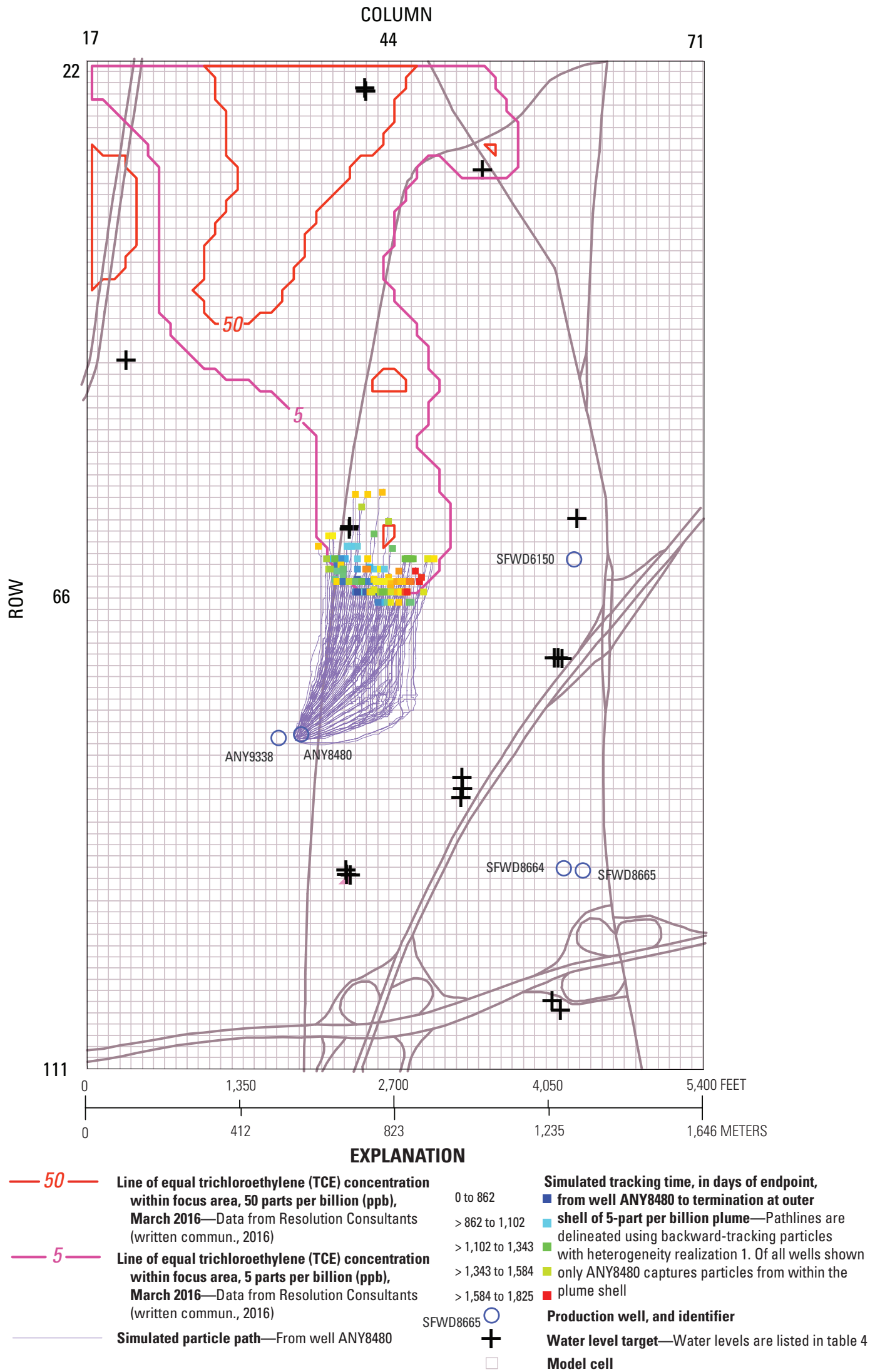

Figure 17. Time of travel of particles backtracked from wells at Bethpage, New York, to the 5-part-perbillion volatile organic compound plume shell. 

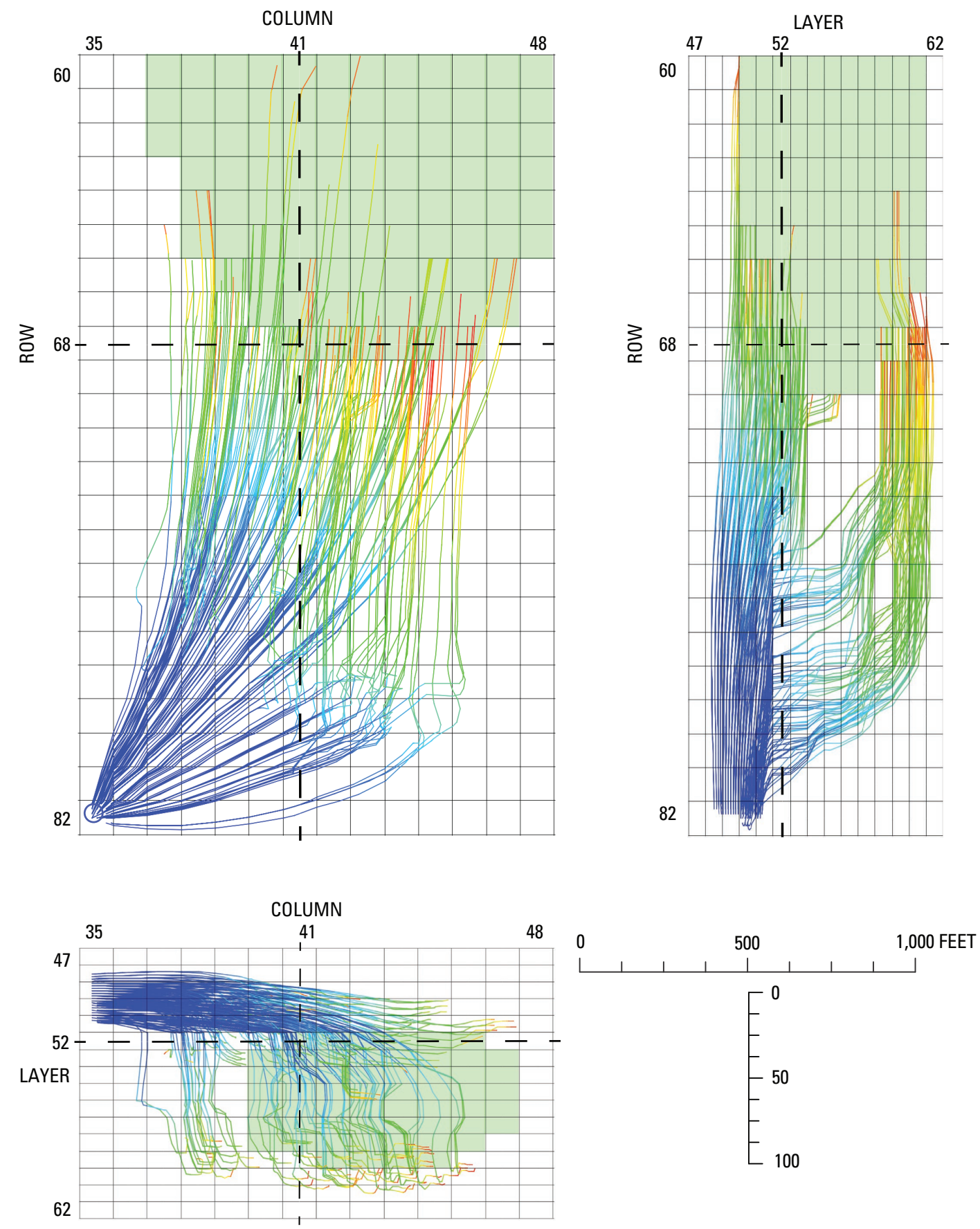

\section{EXPLANATION}

Zone of equal 5 parts per billion (ppb) trichloroethylene (TCE) concentration within focus area, March 2016-Data from Resolution Consultants (written commun., 2016)

Simulated particle pathline-from well ANY8480

— - Line indicating correspondence of plume slice-- column, row, and layer in model

। 0 to 862 Simulated tracking time in days from endpoint, for well ANY8480

| >862 to 1,102 to termination at outer shell of 5-part per billion trichloroethylene

| $>1,102$ to 1,343 plume-Pathlines are delineated using backward tracking with

$\mid>1,343$ to 1,584 heterogeneity realization 1 .

I >1,584 to 1,825

Figure 18. Traveltime of pathlines backtracked from well ANY8480 at Bethpage, New York, to a 5-part per billion volatile organic compound plume shell. 
Varying porosity or traveltime does not affect the MODFLOW-generated flow field; furthermore, these factors are not calibrated using water-level data. To calibrate porosity parameters, a transient state model with time-series solute concentration observations is typically necessary and beyond the scope of this study. In addition, porosity likely varies spatially (spatial porosity variation is not represented as part of this study). Traveltime may be chosen for consistency with proposed water management scenarios.

\section{Variability in Plume Shell Delineation}

The size and shape of the outer skin (shell) of a plume likely changes as a response to stress, and its delineation depends on available data and methods of interpretation. The plume is also moving about 285 feet per year ( $\mathrm{ft} / \mathrm{yr}$ ) along the groundwater flow path (Harre and others, 2011). The effect of plume shell delineation on ZOC analysis may be demonstrated by substitution of the 50-ppb plume shell for the 5-ppb shell (table 7). Figure 19 shows terminations at the 5-ppb shell whereas figure 20 shows terminations at the 50-ppb shell. Terminations occur at the main 50-ppb shell and at two hotspot shells to the southeast. There are a greater number of terminations at the 5-ppb shell than the 50-ppb shells, as the larger 5-ppb shell fully encloses the smaller 50-ppb shells and is closer to potential capture wells. In this method of analysis, particles that do not terminate after a given maximum traveltime are considered to remain active at the end of the simulation and are not counted as shell terminations, although it may be likely they ultimately intersect a plume shell.

\section{Variability in Heterogeneity}

The focus area flow system and ZOCs are affected by aquifer heterogeneity within the Magothy aquifer. Figure 21 shows three views (planimetric along model layer 52, front section along a row 78 , and side sectional along a model column 38) of pathlines overlain on slices of the realization 1 facies zones to suggest how pathlines are guided through model cells of coarser-grained facies and the gravel zone and are slowed or avoid model cells of finer-grained facies. Nine heterogeneity realizations and associated MODFLOW simulations (fig. 11) were generated during the course of this study and are available in the model archive (Misut, 2017). These simulations demonstrate the uncertainty in distribution of fine-grained facies. These heterogeneity realizations are equally probable and potentially result in different simulated water particle pathways and corresponding ZOCs. Table 8 gives a comparison of these realizations. Plume capture (as represented by particles that intersect the plume) varied from about 1 to 3 percent of total well capture (as represented by all particles released at a well) and only well ANY8480 captured plume particles during any simulation of the nine heterogeneous realizations. However, increasing horizontal hydraulic conductivity of the Magothy gravel zone from 100 to $250 \mathrm{ft} / \mathrm{d}$ induces minor plume capture by well ANY9338.

\section{Pumping Wells Independently}

Pumping stresses (table 2) influence spatial characteristics of ZOCs to wells, which show combined effects of well stress and regional flow patterns. Typically, a ZOC is not centered about a well but shifted upgradient along regional flow patterns. For the outlines of 5-year ZOCs of the focus area, this shift is about $700 \mathrm{ft}$ (fig. 22). In addition, the distribution of particles within the outline is denser in the upgradient part. Shifting may increase by increasing regional flow gradient, decreasing porosity, and increasing maximum traveltime associated with the ZOC delineation. As an individual pumping stress increases, the cone of depression generally deepens and spreads out. This can reshape particle pathlines such that a greater number of particles intersect a plume shell. A complex configuration of pumping stresses may influence ZOCs in unexpected ways. To simplify, it is useful to analyze a well's ZOC by hypothetically turning off nearby interfering wells which affect regional hydraulic gradients and shape the ZOC. Figure 22 shows ZOCs of individually stressed wells ANY8480, ANY9338, SFWD8664, SFWD8665, and SFWD6150. These are independent simulations but are overlaid onto one map, in addition to an overlay of the outline of baseline steady-state present conditions ZOCs (all stresses active; fig. 16).

As a result of removing well interference effects, the ZOC of well SFWD6150 is displaced to the south and west. The regional flow gradient in the vicinity of SFWD6150 is lessened due to shutting off pumping of SFWD8664 and 8665. The independent 5-year ZOC of SFWD6150 intersects the 5 -ppb plume because there is less competition for water capture toward the south because of a lack of interference from wells ANY8480, ANY9338, SFWD8664, and SFWD8665. A greater fraction of the total ZOC area is present within the study focus area, although there remains a minor extension to the east (extension not shown in fig. 22).

As a result of removing well interference effects, the ZOCs of wells SFWD8664 and SFWD8665 are displaced toward the plume to the north and west because there is less competition for water capture in these directions because of a lack of interference from wells ANY8480, ANY9338, and SFWD6150. The 5-ppb plume is not intersected. A greater fraction of the total ZOC areas are present within the study focus area, although there are minor extensions to the east (extension not shown in fig. 22). With respect to well SFWD8665, well SFWD8664 is screened deeper, pumps at a lower rate, and is located to the northwest.

As a result of removing well interference effects, the ZOCs of wells ANY8480 and ANY9338 are displaced to the east as there is less competition for water capture in this direction due to interfering wells SFWD8664, SFWD8665, and SFWD6150. The 5-ppb plume is intersected by the ZOC 


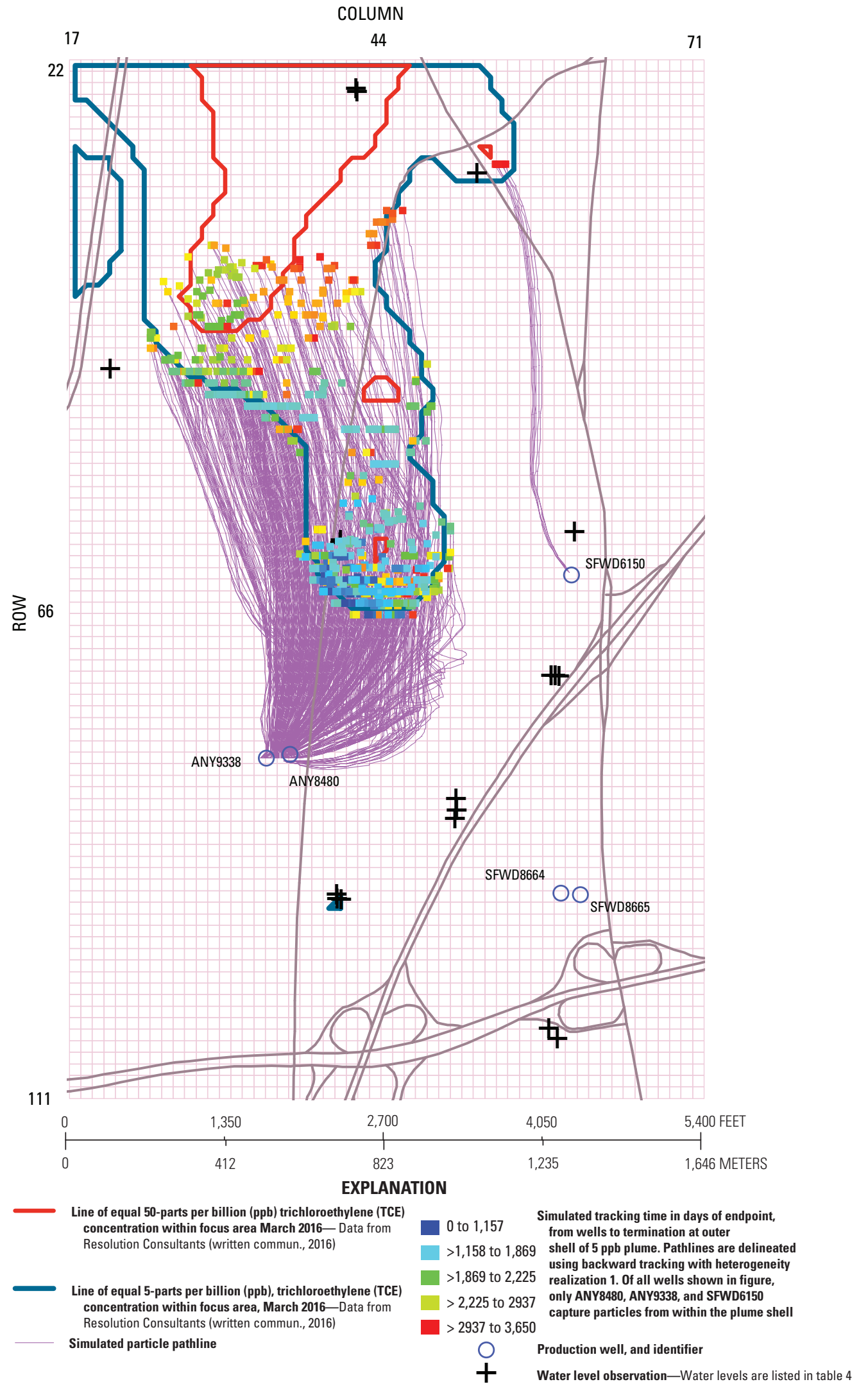

Figure 19. Time of travel of particles backtracked from wells at Bethpage, New York, to a 5-part per billion volatile organic compound plume shell with alternate porosity $(0.15)$ and 10 -year maximum traveltime. 


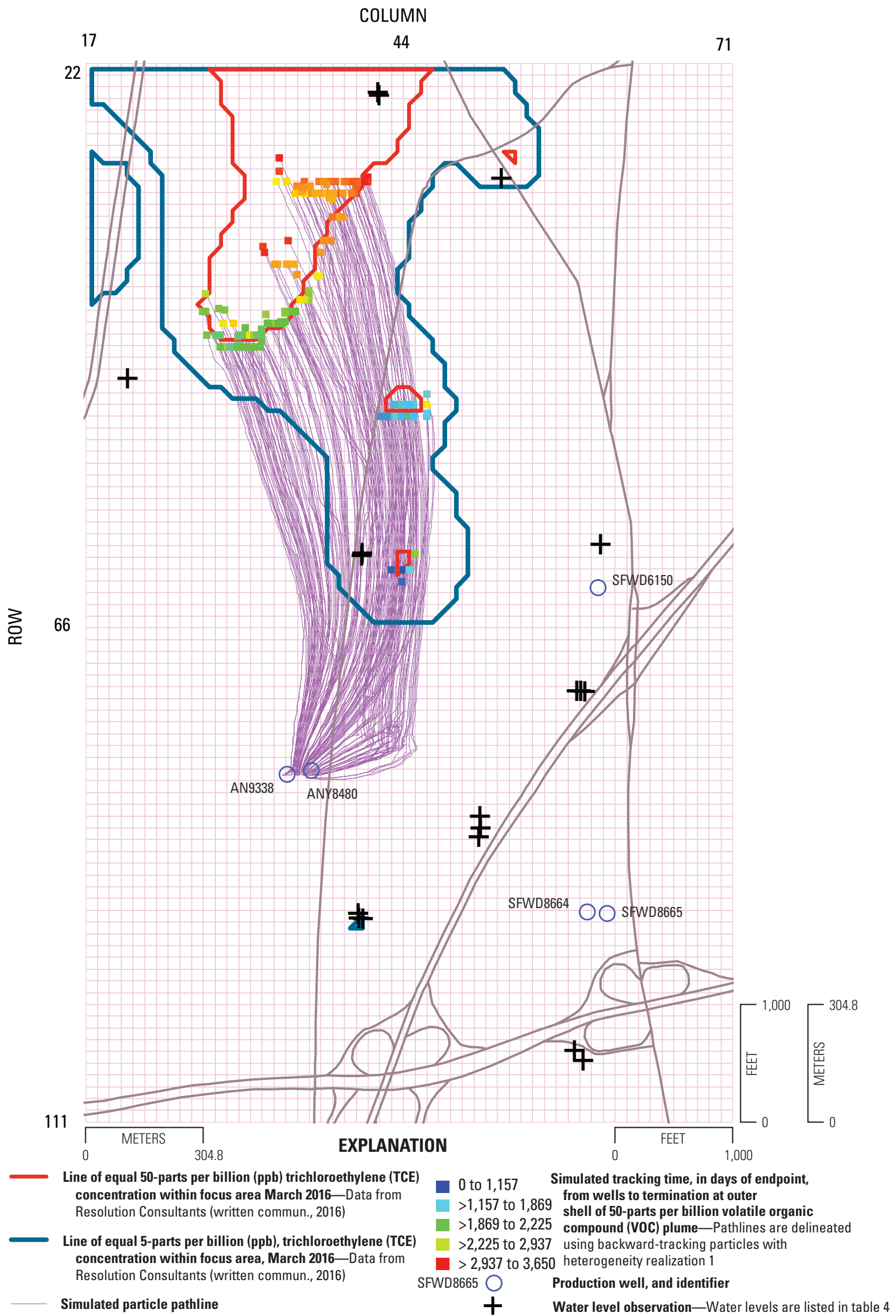

Figure 20. Maximum time of travel of particles backtracked from wells at Bethpage, New York, to 50-part per billion volatile organic compound plume shell with alternate porosity $(0.15)$ and 10 -year maximum traveltime. 


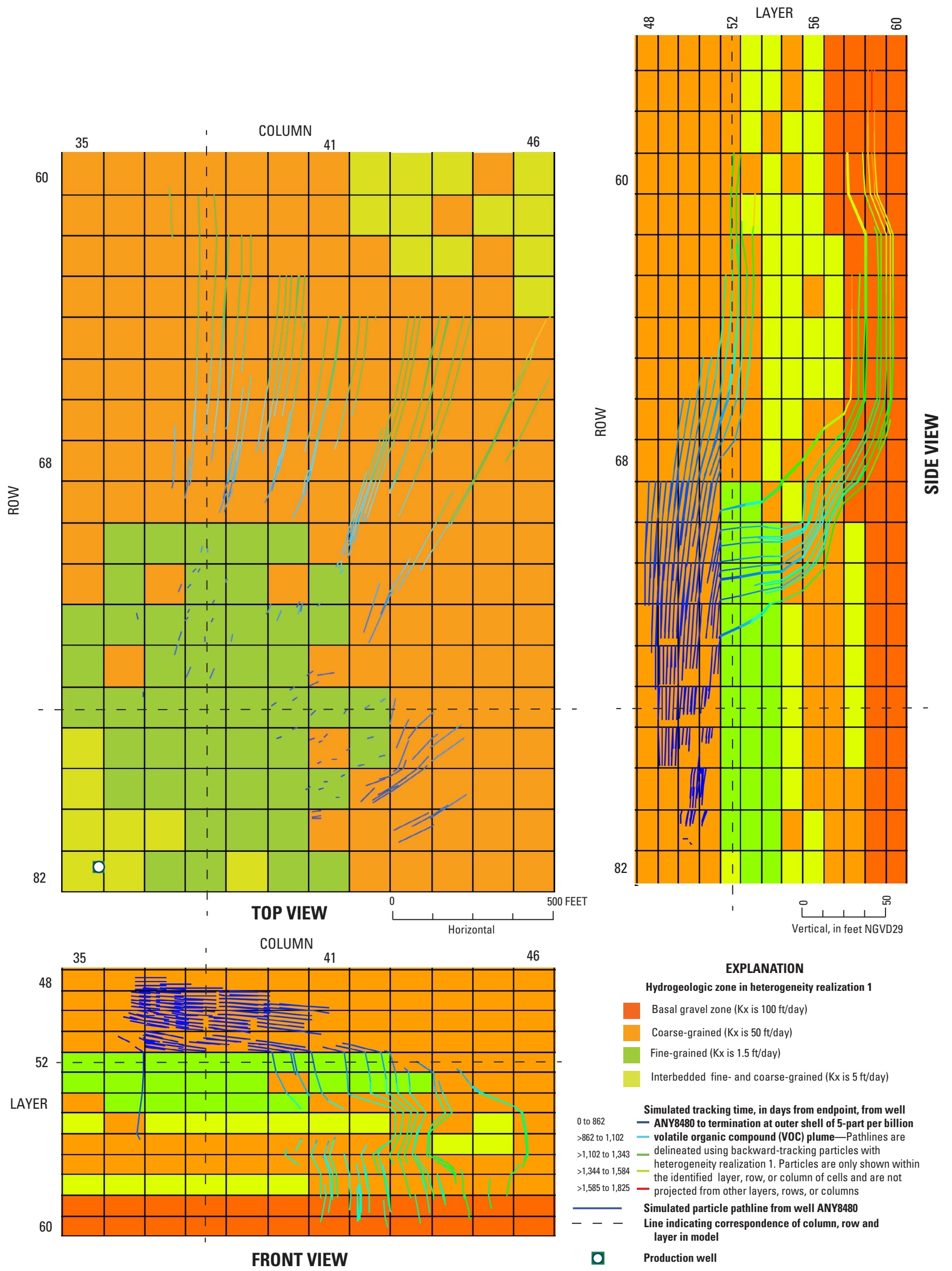

Figure 21. Aquifer heterogeneity realization 1 and traveltime of pathlines backtracked from well ANY8480 at Bethpage, New York. 
Table 8. Comparison of particle terminations at the 5-part per billion plume shell after 5 years for alternate aquifer heterogeneity realization simulations in Bethpage, New York.

[ppb, part per billion]

\begin{tabular}{ccc}
\hline $\begin{array}{c}\text { Realization } \\
\text { number }\end{array}$ & $\begin{array}{c}\text { Particles } \\
\text { remaining active }\end{array}$ & $\begin{array}{c}\text { Particles terminated at } \\
\text { 5-ppb plume shell }\end{array}$ \\
\hline 1 & 13,189 & 188 \\
2 & 13,136 & 241 \\
3 & 13,074 & 303 \\
4 & 13,102 & 275 \\
5 & 13,139 & 238 \\
6 & 13,087 & 290 \\
7 & 12,962 & 415 \\
8 & 13,106 & 271 \\
9 & 13,055 & 322 \\
\hline
\end{tabular}

of either well. Although the two ZOCs are effectively split into eastern (ANY8480) and western (ANY9338) half spheres during the steady-state combined-stress simulation, during the individual stress simulations the two ZOCs are full spheres of similar size and shape due to similar pumping rates and well screen depths (table 2). With respect to well ANY9338, the slight displacement of the ZOC of well ANY8480 to the east is because of the eastern location of well ANY9338. There are minor extensions to the west of the ZOCs of both wells (extension not shown in fig. 22).

\section{Discussion}

To better understand factors affecting the ZOCs of wells at Bethpage, advective particle tracking analysis may be conducted in forward and backward modes. ZOCs were delineated for present steady-state conditions. Analyses varying pumping rate, porosity, particle traveltime, and plume shell delineation were used to determine controls on the size and shape of ZOCs. Through transitional probability analyses, the robustness of the estimates for hydraulic conductivity and, therefore, ZOCs were demonstrated in this report. Discussion topics include the ability of wells to capture the plume, the optimal pumping rate configuration, and modeling limitations.

\section{Capture of VOCs}

The results of this study indicate that the majority of simulated water particles captured by wells originate from areas other than 5 and (or) 50-ppb plume shells. Within 5 years, about 1 to 3 percent of particles captured by well ANY 8480 originate from the 5-ppb plume, and no other wells capture any plume particles. Given the baseline particle tracking methodology, which seeds a limited number of particles at well screens (total of 13,377 particles in arrays of 7 by 7 by 7 particles per model cell representing a screen zone) and terminates particles at the plume shell outer boundary if reached before a maximum traveltime of 5 years, no particles originating within the 50-ppb plume were observed to be captured. However, by varying combinations of porosity, maximum traveltime, pumping rate, and aquifer heterogeneity realization, a small amount of particles may be induced to originate from the southernmost isolated area of the 50-ppb plume shell.

By using the alternate particle tracking method where particles are started throughout the interior of the 50-ppb plume shell (one per model cell or 4,813 total) and tracked forward for a maximum of 5 years or until capture by wells, one particle is captured by well ANY8480 (fig. 23), and originates from the southernmost isolated area. During this simulation, the majority of particles started within the 50-ppb plume do not travel beyond the boundaries of the 5-ppb plume. Particles are also forward tracked from the 5-ppb plume with one per model cell or 22,958 total (fig. 23). The subset of 5-ppb forward pathlines that represent well plume capture are similar in number and shape to those of backtracked pathlines as shown in figure 17.

\section{Optimal Pumping}

Model simulations described in this report provide some direction for managing pumping rates with respect to minimizing and (or) isolating plume capture. Optimization routines such as GWM 2005 (Ahlfeld and others, 2009) could be used to more precisely maximize pumping and minimize plume capture. The current pumpage configuration may be considered close to optimal in the sense that, based on the present steady-state simulation, only one well captures plume water, whereas there is a potential for more wells to capture plume water. During the simulation, the wellfield of wells ANY 8480 and ANY9338 is the only wellfield capturing a plume within 5 years. About 1 to 3 percent of particles captured by well ANY8480 is sourced from the 5-ppb plume. However, this assumes a continuous steady-state pumpage configuration; in practice it is likely that there are times when well ANY8480 is not pumping but well ANY9338 is pumping. In these cases, the ZOC of well ANY9338 may begin to revert to an individual-stress ZOC as shown in figure 22, capturing a small amount of plume water.

With optimal pumping, continuous operation of well ANY8480 may reduce plume-water capture by well ANY9338. In addition, pumping of either well ANY8480 or well ANY9338 may be optimized to shift the ZOC of well SFWD6150 away from the 5-ppb plume because all these wells are in competition to capture water from the general area of the southern tongue of the 5-ppb plume. However, in the future, well SFWD6150 may begin to capture water originating in the 5-ppb plume because the plume itself is moving in a 
17

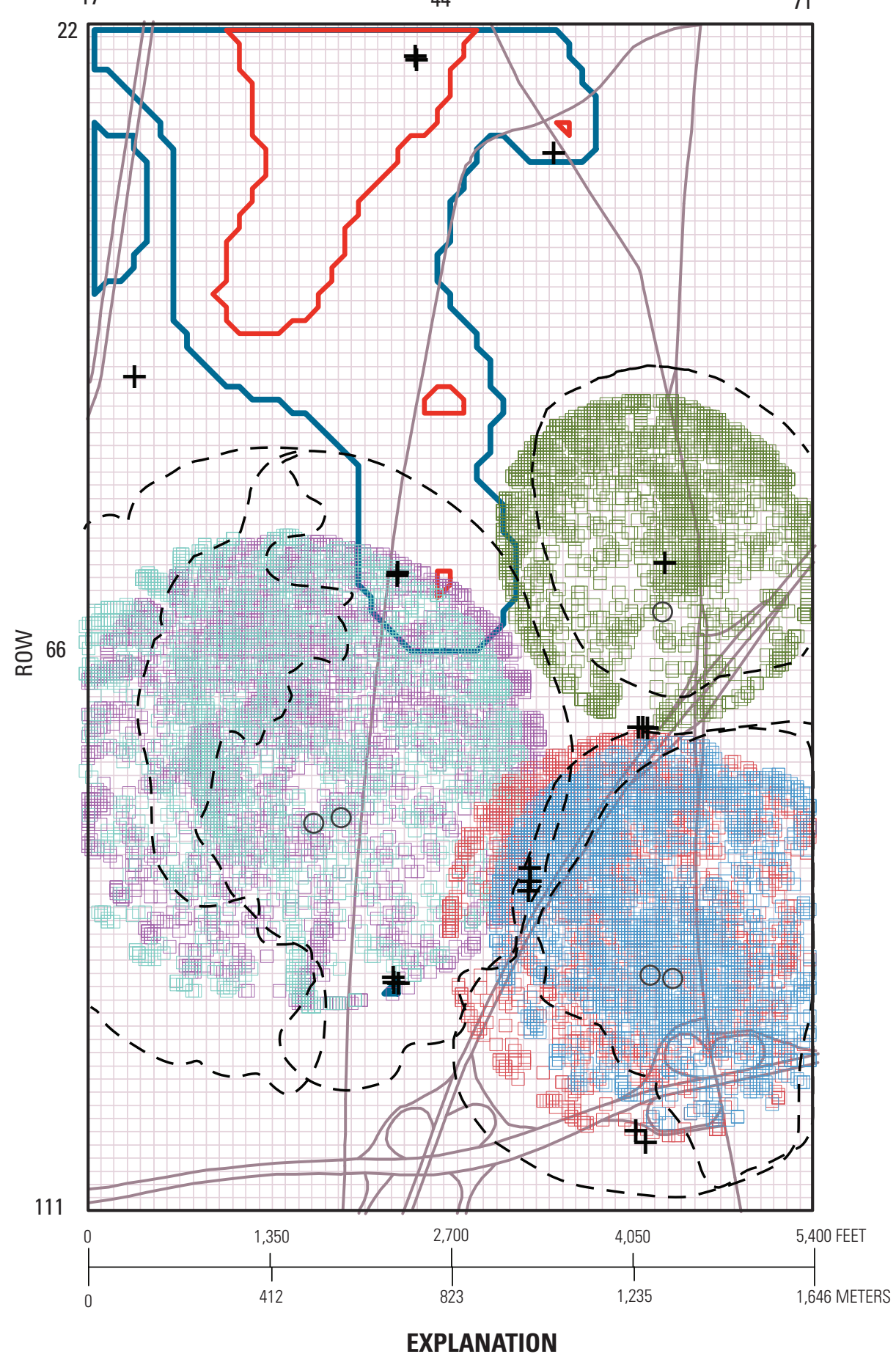

Simulated individually-pumped zones SFWD8664 $\square$ of contribution, heterogeneity ANY9338 $\square$ realization $1-$ Zones are delineated ANY8480 using backward-tracking particle ANY8480 $\square$ endpoints and represent SFWD8665 $\square$ projected maximum three-dimensional SFWD6150 $\square$ extents. Color corresponds to well

Production well

$+\quad$ Water level target-Water levels are listed in table 4
Figure 22. Zones of contribution represented as projections of maximum extent of threedimensional particle endpoints tracked backward from individual pumping stresses at South Farmingdale Water District wells SFWD6150, SFWD8664, SFWD8665, and Aqua NY wells ANY8480 and ANY9338 at Bethpage, New York, after 5 years, simulated using present steady-state conditions model realization 1 . 

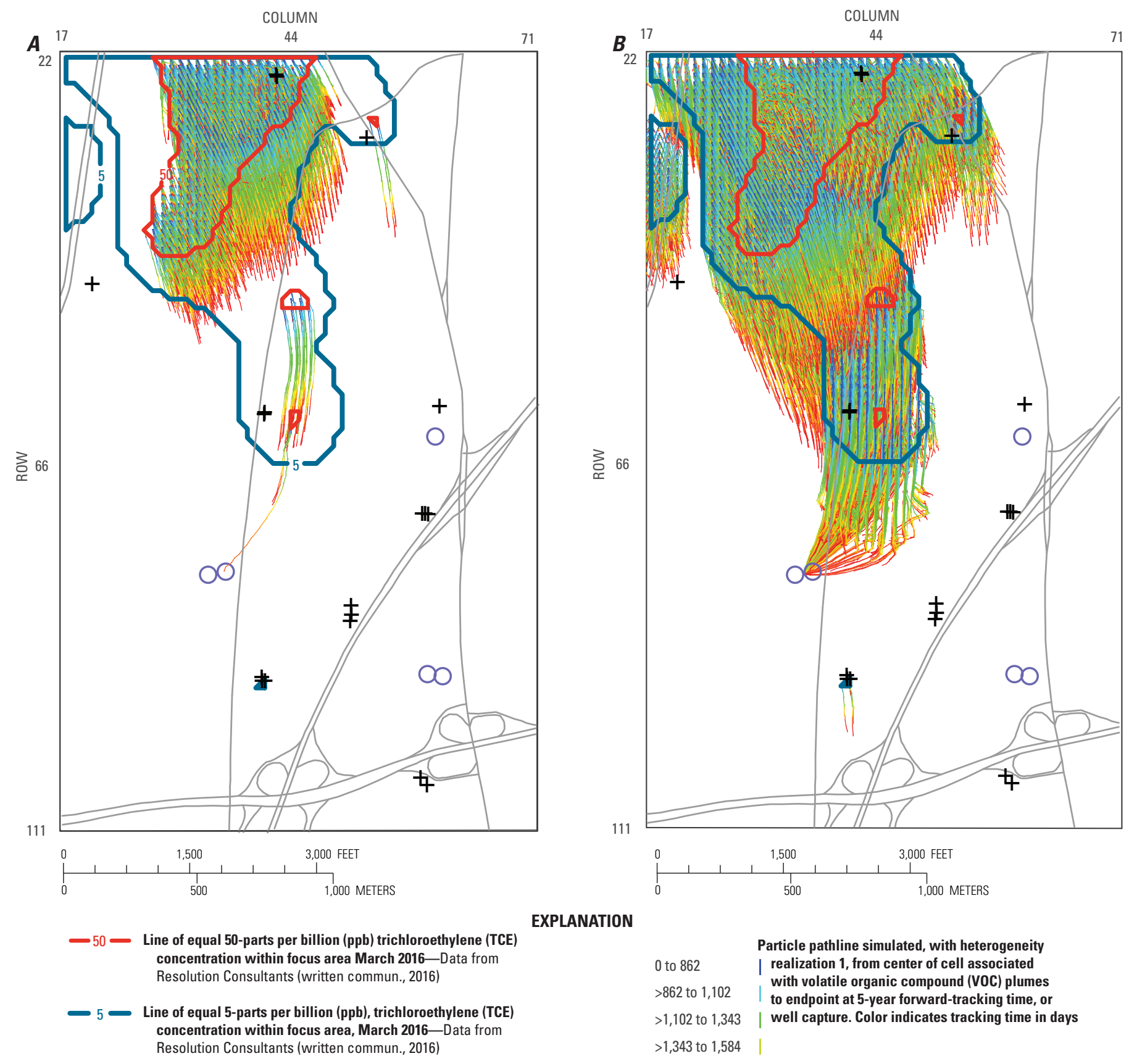

EXPLANATION

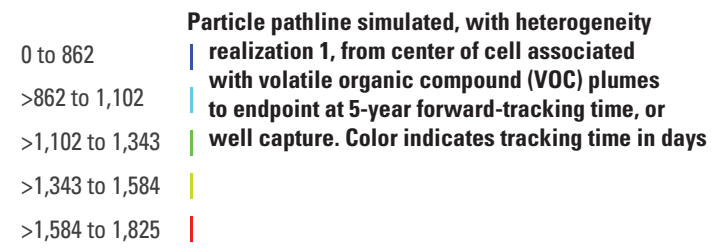

+ Water level target-Water levels are listed in table 4

$\bigcirc$ Production well

Figure 23. Traveltime and pathlines of forward-tracked particles started within interior of $A$, 50- and $B, 5$-part per billion volatile organic compound plumes. 
south-southeasterly direction along the regional flow patterns. Because of the extremely low percentage of plume particles captured by well ANY8480, this well is not in an ideal position to capture plume particles at the current time, in the context of present steady-state conditions. Determining detailed optimal rates and locations of remedial wells is beyond the scope of this study.

\section{Limitations of Modeling}

The calibrated steady-state, present conditions MODFLOW model represents the groundwater system reasonably well given limitations such as available computing resources, borehole data, water-level observations, records pertaining to hydrologic stresses, and independent estimates of model parameters. MODFLOW limitations may impact the accuracy of delineations of the zones of contribution to pumping wells because particle tracking analyses follow flow fields simulated by MODFLOW. To evaluate limitations related to characterization of aquifer heterogeneity, nine realizations of the hydrogeologic framework were developed using T-PROGS and a fine level of vertical MODFLOW discretization. These alternates were subjected to particle tracking analysis of ZOCs.

In addition to limitations of the MODFLOW model, there are limitations to the MODPATH particle tracking technique.

Because forward-tracking and backtracking results may differ, both were conducted. The MODPATH technique is not calibrated through comparison of particle tracking results with relevant observations of the actual system, such as water quality data or changes in the plume size and shape over time. Porosity is an uncalibrated parameter and a wide range of values is given in the literature. If a greater porosity value is specified in the model, then particle velocities decrease, and ZOC area also decreases. Particle tracking uses advective transport only and does not account for adsorption, degradation, diffusion, and other processes that may reduce TVOC concentrations in groundwater. Additionally, ZOCs can change with hydraulic conductivity and other parameter changes. Because of the uncertainty associated with hydraulic conductivity, boundary conditions, withdrawals, flows, and recharge, estimated ZOCs should be viewed as the most likely areas and be subjected to ranges and alternate simulations. It is possible that the source loading of the OU2 VOC plume involves dense nonaqueous phase liquids; however, no source loading mechanisms of any type were considered in model development and calibration. ZOCs and particle pathlines are simulated with present conditions steady-state models. Pathlines tracked using steady-state models are similar to pathlines tracking using transient state models that represent recurring stress cycles such as seasonal recharge patterns and pumping well operations as described in Reilly and Pollock (1995); however, simulation of long-term changes in model stress may result in different simulated pathlines. In this report, the steady-state models and a static plume configuration are used to delineate ZOCs; however, there are likely some transient-state variations that may be represented to further improve delineation accuracy.

\section{Summary and Conclusions}

Downgradient of the Naval Weapons Industrial Reserve Plant at Bethpage, New York, the OU2 plume of dissolved volatile organic compounds (VOCs) is migrating along the direction of groundwater flow. To understand the effect of this migration on downgradient production wells, it is useful to understand the mechanisms of plume migration. In this study, a numerical model was used to simulate advective processes. This modeling was part of a study by the U.S. Geological Survey in cooperation with the Naval Facilities Engineering Command to delineate groundwater near the Naval Weapons Industrial Reserve Plant in Bethpage, New York. The plume was divided into two regions or volumes corresponding to plume shell isosurfaces of 5 and 50-part per billion trichloroethylene (TCE) concentration.

Model simulations were conducted to improve understanding of how the following factors affect production well zones of contribution: heterogeneity in the Magothy aquifer, variability in pumpage rate, and variability in porosity. Both forward- and backward-particle tracking analyses were conducted and essentially yielded the same conclusions. The forward-tracking simulations focus on the fate of the plume, while the backward-tracking simulations focus on particle movement processes that are affected by well hydraulic stress. The number of backward-tracked particles that were sourced from within the plume within 5 years, was less than 1.5 percent of total particles released (most particles captured by wells arrive from other directions than the plume). Well ANY8480 captured the vast majority of particles sourced from the plume, but these particles still amounted to only about 1 to 3 percent of total particles captured by the well. Most particles were not sourced from the plume within 5 years of time, coming instead from points such as to the west and south of the plume. The number of backward-tracked particles that were sourced from within the plume shell delineation within 30 years increased to about 12 percent of total particles released. In an unlimited time frame, all particles originate as water-table recharge; however, in the 5 to 30 year time frame, most particles originate within the flow system, having recharged previously.

Because the model is a simplification of the real conditions and because values of important physical controlling parameters are to a large extent uncertain, this analysis considers variations of both parameter values and hydrologic conditions in order to bracket important factors that control zones of contribution. By use of borehole logs, a transitional probability approach generated alternate representations of heterogeneity within the Magothy aquifer. Coarse-grained facies comprise about 73 percent of the Magothy aquifer material. Fine-grained and interbedded facies 
were laterally discontinuous, thickening towards the south, and statistically comprise 8 and 19 percent of the total aquifer volume realized in the focus area of interest surrounding wells SFWD6150, SFWD8664, SFWD8665, ANY8480, and ANY9338. Through transitional probability analyses, the effect of heterogeneity variation on simulated zones of contribution was demonstrated.

\section{References Cited}

Ahlfeld, D.P., Baker, K.M., and Barlow, P.M., 2009, GWM2005-A groundwater-management process for MODFLOW-2005 with local grid refinement (LGR) capability: U.S. Geological Survey Techniques and Methods, book 6, chap. A33, 65 p. [Also available at https://pubs.er.usgs.gov/ publication/tm6a33.]

Arcadis CE, Inc., 2003, Comprehensive groundwater model report: Naval Facilities Engineering Command, [n.p.]

Arcadis CE, Inc., 2009, Remedial investigation report (study area groundwater), Operable Unit 3 (former Grumman settling ponds), Bethpage, New York: Melville, N.Y., Arcadis CE, Inc., 111 p., appendixes.

Arcadis CE, Inc., 2010, Study area operable unit 3 (former Grumman settling ponds), Bethpage, New York, NYSDEC site \#1-30-003A2010: Melville, N.Y., Arcadis CE, Inc. draft comprehensive feasibility study, v. 2, [n.p.]

Arcadis CE, Inc., 2011, Operable unit 2, Bethpage, New York, NYSDEC site \#1-30-003A2010: Melville, N.Y., Arcadis $\mathrm{CE}$, Inc. annual groundwater monitoring report, [n.p.].

Busciolano, R.J., 2005, Statistical analysis of long-term hydrologic records for selection of drought-monitoring sites on Long Island, New York: U.S. Geological Survey Scientific Investigations Report 2004-5152, 47 p. [Also available at https://pubs.er.usgs.gov/publication/sir20045152.]

Buxton, H.T., and Smolensky, D.A., 1999, Simulation of the effects of the groundwater flow system of Long Island, New York: U.S. Geological Survey Water-Resources Investigations Report 98-4069, 57 p. [Also available at https://pubs.er.usgs.gov/publication/wri984069.]

Carle, S.F., 1999, T-PROGS-Transition probability geostatistical software (version 2.1): University of California, Davis, 78 p. [Also available at http://gmsdocs.aquaveo. com/t-progs.pdf.]

Como, M.D., Finkelstein, J.S., Monti, Jack, Jr., and Busciolano, Ronald, 2016, Geospatial dataset of water-table and potentiometric-surface altitudes in the upper glacial, Magothy, and Lloyd aquifers of Long Island, New York, AprilMay 2013: U.S. Geological Survey data release, accessed November 2016 at https://doi.org/10.5066/F7RV0KSD.
Franke, O.L., Reilly, T.E., Pollock, D.W., and LaBaugh, J.W., 1998, Estimating areas contributing recharge to well-Lessons from previous studies: U.S. Geological Survey Circular 1174, 14 p. [Also available at https://pubs.er.usgs.gov/ publication/cir1174.]

Getzen, R.T., 1977, Analog-model analysis of regional threedimensional flow in the ground-water reservoir of Long Island, New York: U.S. Geological Survey Professional Paper 982, 49 p. [Also available at https://pubs.er.usgs.gov/ publication/pp982.]

Harbaugh, A.W., 2005, MODFLOW-2005, the U.S. Geological Survey modular ground-water model-The groundwater flow process: U.S. Geological Survey Techniques and Methods, book 6, chap. A16, [variously paginated]. [Also available at https://pubs.er.usgs.gov/publication/tm6A16.]

Harre, K.A., Gavaskar, A., Humann, R., Misut, P.E., Newell, C., Rectanus, H., and Widdowson, M., 2011, Remedy Optimization Team report for the Bethpage groundwater plume remedy: Norfolk, Va., Naval Facilities Engineering Command, [n.p.].

Konikow, L.F., Hornberger, G.Z., Halford, K.J., and Hanson, R.T., 2009, Revised multi-node well (MNW2) package for MODFLOW ground-water flow model: U.S. Geological Survey Techniques and Methods, book 6, chap. A30, 67 p. [Also available at https://pubs.er.usgs.gov/publication/ tm6A30.]

McClymonds, N.E., and Franke, O.L., 1972, Water-transmitting properties of aquifers on Long Island, New York: U.S. Geological Survey Professional Paper 627-E, 24 p. [Also available at https://pubs.er.usgs.gov/publication/ pp627E.]

McDonald, M.G., and Harbaugh, A.W., 1988, A modular three-dimensional finite-difference ground-water flow model: U.S. Geological Survey Techniques of WaterResources Investigations, book 6, chap. A1, 586 p. [Also available at https://pubs.er.usgs.gov/publication/twri06A1.]

Miller, J.F., and Frederick, R.H., 1969, The precipitation regime of Long Island, N.Y.: U.S. Geological Survey Professional Paper 627-A, 21 p. [Also available at https://pubs.er.usgs.gov/publication/pp627A.]

Misut, P.E., 2011, Simulation of groundwater flow in a volatile organic compound-contaminated area near Bethpage, Nassau County, New York-A discussion of modeling considerations. U.S. Geological Survey Open-File Report 20111128, 19 p., accessed June 2016 at https://pubs.er.usgs.gov/ publication/ofr20111128. 
Misut, P.E., 2014, Simulation of zones of contribution to wells at site GM-38, Naval Weapons Industrial Reserve Plant, Bethpage, New York: U.S. Geological Survey Scientific Investigations Report 2014-5036, 58 p., accessed June 2016 at https://doi.org/10.3133/sir20145036.

Misut, P.E., 2018, MODFLOW-2005 used to simulate zones of contribution to wells south of Naval Weapons Industrial Reserve Plant, in Bethpage, Levittown, Farmingdale, and South Farmingdale, New York: U.S. Geological Survey data release, https://doi.org/10.5066/F770809V.

Misut, P.E., and Aphale, Omkar, 2014, Simulation of groundwater flow pathlines and freshwater/saltwater transition zone movement, Manhasset Neck, Nassau County, New York: U.S. Geological Survey Scientific Investigations Report 2013-5201, 44 p., accessed June 2016 at https://doi.org/10.3133/sir20135201.

Misut, P.E., and Busciolano, R.J., 2009, Hydraulic properties of the Magothy and upper glacial aquifers at Centereach, Suffolk County, New York: U.S. Geological Survey Scientific Investigations Report 2009-5190, 23 p., accessed June 2016 at https://pubs.er.usgs.gov/publication/ $\operatorname{sir} 20095190$.

Monti, Jack, Jr., Como, Michael, and Busciolano, Ronald, 2013, Water-table and potentiometric-surface altitudes in the upper glacial, Magothy, and Lloyd aquifers beneath Long Island, New York, April-May 2010: U.S. Geological Survey, Scientific Investigations Map 3270, 4 sheets, scale 1:125,000, accessed June 2016 at https://doi.org/10.3133/sim3270.

Morrissey, D.J., 1989, Estimation of the recharge area contributing water to a pumped well in a glacial-drift, river-valley aquifer: U.S. Geological Survey Water-Supply Paper 2338, 41 p. [Also available at https://pubs.er.usgs.gov/publication/ wsp2338.]

Nassau County Department of Public Works, 2009, Nassau County storm water management program plan: Nassau County Department of Public Works, 34 p. [Also available at https:/www.nassaucountyny.gov/DocumentCenter/ View/1296.]

Naval Facilities Engineering Command, 2003, Naval weapons industrial reserve plant, Bethpage, New York; Operable unit 2-Groundwater; New York State registry 1-30-003B [April (revision 1)]: Naval Facilities Engineering Command record of decision, [variously paginated]. [Also available at https://www.navfac.navy.mil/niris/MID_ATLANTIC/BETHPAGE_NWIRP/OU\%2000002/ADMIN\%20 RECORD/N90845_000694.pdf.]

New York State Department of Environmental Conservation, 2016, Grumman Aerospace-Bethpage Facility: New York State Department of Environmental Conservation remedial options report, work assignment D007625-23, July, [n.p.].
New York State Orthoimagery Program, 2010, Orthoimagery in Nassau County: New York State Geographic Information Systems clearinghouse, accessed June 2016 at http://gis.ny.gov/gateway/mg/2010/nassau/.

Poeter, E.E., Hill, M.C., Banta, E.R., Mehl, Steffen, and Christensen, Steen, 2005, UCODE_2005 and six other computer codes for universal sensitivity analysis, calibration, and uncertainty evaluation: U.S. Geological Survey Techniques and Methods, book 6, chap. A11, 283 p. [Also available at https://pubs.er.usgs.gov/publication/tm6A11.]

Pollock, D.W., 1989, Documentation of a computer program to compute and display pathlines using results from the U.S. Geological Survey modular three-dimensional finitedifference ground-water flow model: U.S. Geological Survey Open-File Report 89-381, 188 p. [Also available at https://pubs.er.usgs.gov/publication/ofr89381.]

Pollock, D.W., 2012, User guide for MODPATH version 6-A particle-tracking model for MODFLOW: U.S. Geological Survey Techniques and Methods, book 6, chap. A41, 58 p. [Also available at https://pubs.er.usgs.gov/publication/ tm6A41.]

Reilly, T.E., and Pollock, D.W., 1993, Factors affecting areas contributing recharge to wells in shallow aquifers: U.S. Geological Survey Water-Supply Paper 2412, 21 p. [Also available at https://pubs.er.usgs.gov/publication/ wsp2412.]

Reilly, T.E., and Pollock, D.W., 1995, Effect of seasonal and long-term changes in stress on sources of water to wells: U.S. Geological Survey Water-Supply Paper 2445, 25 p. [Also available at https://pubs.er.usgs.gov/publication/ wsp2445.]

Rozell, Daniel, 2010, Urbanization and trends in Long Island stream base flow, in Long Island Geologists Conference, April 10, 2010, Stony Brook, N.Y.: Stony Brook, State University of New York, 12 p. [Also available at http://hdl.handle.net/1951/50987.]

Seaburn, G.E., and Aronson, D.A., 1974, Influence of recharge basins on the hydrology on Nassau and Suffolk Counties, Long Island, New York: U.S. Geological Survey WaterSupply Paper 2031, 66 p. [Also available at https://pubs.er.usgs.gov/publication/wsp2031.]

Smolensky, D.A., Buxton, H.T., and Shernoff, P.T., 1989, Hydrogeologic framework of Long Island, New York: U.S. Geological Survey Hydrologic Investigations Atlas 709, 3 sheets, scale 1:250,000. [Also available at https://pubs.er.usgs.gov/publication/ha709.] 
Smolenksy, D.A., and Feldman, S.M., 1995, Three-dimensional advection transport of volatile organic compounds in ground water beneath an industrial/residential area of Nassau County, New York: U.S. Geological Survey WaterResources Investigations Report 92-4148, 53 p. [Also available at https://pubs.er.usgs.gov/publication/wri924148.]

Tetra Tech, 2012a, Letter work plan-Water level and pumping test activities to support GM-38 capture zone analysis: Bethpage, N.Y., Naval Weapons Industrial Reserve Plant, [n.p.].

Tetra Tech, 2012b, Study of alternatives for management of impacted groundwater at Bethpage-Evaluation of remedial alternatives for the Bethpage plume: Tetra Tech N62470 08-D-1001, [n.p.].

U.S. Geological Survey, 1996, Publications-Policy on documenting the use of ground-water simulation in project reports: U.S. Geological Survey Office of Ground Water Technical Memorandum No. 96.04, accessed June 2016 at http://water.usgs.gov/admin/memo/GW/gw96.04.html.

U.S. Geological Survey, 2003, Terminology used in studies of the source of water to wells under steady-state conditions: U.S. Geological Survey Office of Ground Water Technical Memorandum No. 2003.02, 4 p. [Also available at http://water.usgs.gov/admin/memo/GW/gw03.02.html.]

U.S. Geological Survey, 2016a, ModelMuse version 3.9: U.S. Geological Survey groundwater software web page, accessed June 2016 at https://water.usgs.gov/nrp/ gwsoftware/ModelMuse/ModelMuse.html.
U.S. Geological Survey, 2016b, MODFLOW and related programs: U.S. Geological Survey groundwater software web page, accessed June 2016 at https://water.usgs.gov/ogw/ modflow/.

U.S. Geological Survey, 2017a, USGS 01309500 Massapequa Creek at Massapequa NY: U.S. Geological Survey National Water Information System website, accessed July 5, 2017, at https://waterdata.usgs.gov/nwis/inventory?agency code $=$ USGS\&site $\_$no $=01309500$.

U.S. Geological Survey, 2017b, USGS 01309950 Bellmore Creek at Bellmore NY: U.S. Geological Survey National Water Information System website, accessed July 5, 2017, at https://waterdata.usgs.gov/nwis/inventory?agency code $=$ USGS\&site no $=01309950$.

U.S. Geological Survey, 2017c, USGS surface-water data for New York: U.S. Geological Survey National Water Information System website, accessed January 2017 at https://nwis.waterdata.usgs.gov/ny/nwis/sw.

U.S. Geological Survey, 2017d, USGS water data for the Nation: U.S. Geological Survey National Water Information System data release, accessed January 2017 at https://doi.org/10.5066/F7P55KJN.

Winston, R.B., 2009, ModelMuse-A graphical user interface for MODFLOW-2005 and PHAST: U.S. Geological Survey Techniques and Methods, book 6, chap. A29, 52 p. [Also available at https://pubs.er.usgs.gov/publication/tm6A29.]

Zheng, Chunmiao, 1990, MT3D-A modular three-dimensional transport model for simulation of advection, dispersion and chemical reactions of contaminants in groundwater systems: U.S. Environmental Protection Agency, 170 p. 



\section{Glossary}

Definitions pertaining to regulation are from the New York State Department of Environmental Conservation and the U.S. Environmental Protection Agency.

advection A transport mechanism of a substance by a fluid due to the fluid's bulk motion in a particular direction.

anisotropy The property of being directionally dependent, as opposed to isotropy, which implies identical properties in all directions. An example of an anisotropic material is wood, which is easier to split along its grain than against it.

area contributing recharge The surface area on the boundary of the groundwater system that delineates the location of the water entering the groundwater system that eventually flows to the well.

composite scaled sensitivity Composite scaled sensitivities indicate the information content of all the observations for the estimation of a parameter.

cone of depression Conical-shaped depression of head or water level surrounding a pumped well.

confining unit A layer of geologic material that impedes the movement of water into and (or) out of an aquifer.

constant flux boundary A boundary condition at a model location where an amount of inflow or outflow is fixed, requiring a variable amount of water to flow towards or away from the location to satisfy the condition. Simulated head at constant flux boundary condition may vary.

constant head boundary A boundary condition at a model location where head is fixed, requiring a variable amount of water to flow towards or away from the location to satisfy the condition.

diffusion The spread of particles through random motion from regions of higher concentration to regions of lower concentration.

dispersion The spreading of mass from highly concentrated to less concentrated areas.

ending zone A model region where a particle pathlines is terminated. finite difference technique A numerical method to solve mathematical problems through use of a rectangular grid.

forward particle tracking A method in which particles are tracked forward through time.

glacial moraine A glacial deposit upgradient of the ice limit, typically of relatively low hydraulic conductivity.

glacial outwash plain A glacial deposit downgradient of the ice limit, typically of relatively high hydraulic conductivity.

governing partial differential equation A multidimensional mathematical equation with change terms, representing a physical process.

hard data A term that is used in the T-PROGs literature to describe data that are not subject to modification, but are fixed at initial values. The model realizes the framework geometry around the hard data but not at the hard data. It is important to emphasize that hard data are honored. The soft data are the realization, which forms an input dataset for MODFLOW.

hot spot A small area of intense or important activity embedded in a larger area of relative calm. In this study, the GM-38 hot spot refers to a TVOC plume shell located near the GM-38 pumping wells.

interim remedial measure An interim remedial measure is a discrete set of activities to address both emergency and nonemergency site conditions, which can be undertaken without extensive investigation and evaluation, to prevent, mitigate, or remedy human exposure and (or) environmental damage or the consequences of human exposure and (or) environmental damage attributable to a site.

least squares minimization The best fit in the least-squares; minimizes the sum of squared residuals, a residual being the difference between an observed value and the fitted value provided by a model. 
Lloyd aquifer The Lloyd aquifer is the deepest and oldest of Long Island's aquifers, composed of fine to coarse sand and gravel with a clayey matrix and some layers of silty or solid clay. The aquifer was derived from stream erosion of areas to the north and west during the late Cretaceous age.

Magothy aquifer The largest of Long Island's aquifers, composed of river delta sediments that were deposited on top of the Raritan Formation during the late Cretaceous age. Fine to medium sand is interbedded with clay and sandy clay of moderate permeability and silt and clay of low to very low permeability. The basal zone commonly contains coarse sand and gravel.

Markov chain A process that consists of a finite number of known probabilities pij, where pij is the probability of moving from state $\mathrm{j}$ to state $\mathrm{i}$.

model archive A set of files that may be used to reproduce a model simulation.

molecular diffusion Transport or movement of individual molecules through a fluid by means of random, individual movements of the molecules.

monitoring well A well (often small-diameter) drilled for measuring water levels and testing water quality. Monitoring wells are not typically used to supply water.

onsite containment system A system used to prevent contaminants from migrating offsite.

operable unit An operable unit addresses geographical portions of a site, specific site problems, or initial phases of an action, or may consist of any set of actions performed overtime or any actions that are concurrent but located in different parts of a site.

particle tracking analysis Water particles tracked through time assuming they are transported by advection using a simulated flow field. Particles can be tracked either forward in time or backward in time. This qualitative approach does not conserve mass.

plume A body of contaminated groundwater flowing from a specific source. The movement of the groundwater is influenced by such factors as local groundwater-flow patterns, the character of the aquifer in which groundwater is contained, and the density of contaminants. porosity A measure of the void spaces in a material; also a fraction of the volume of voids over the total volume between 0 and 1 or as a percentage between 0 and 100 percent.

Raritan confining unit Underlies the Magothy aquifer, derived from stream erosion of areas to the north and west during the late Cretaceous age.

record of decision A public document that explains which cleanup alternatives will be used to clean a contaminated site.

remedial investigation An investigation to determine the nature and extent of contamination, assess the treatability of site contamination, and evaluate the potential performance and cost of treatment technologies.

residual The error in a result.

robustness The ability of system to resist change without adapting its initial stable configuration.

sensitivity analysis A technique for systematically changing parameters in a model to determine the relative effects of such changes.

starting point In a forward tracking particle analysis, an origination point.

steady state A system whose behavior is unchanging with time.

tracking time In a forward tracking particle analysis, the amount of time elapsed between particle starting and particle termination.

transiogram A transition probability-lag diagram.

transitional probability The probability of going from a given state to another state in a Markov chain.

upper glacial aquifer An unconfined aquifer directly underlying the Long Island ground surface. The upper glacial aquifer was formed during the last ice age.

water table The top of an unconfined aquifer below which the pore spaces are generally saturated; the level in the saturated zone.

weak sink cell In a particle analysis, a cell where there is a partial throughput of water. A decision may be made to allow the particle to track through the cell, or terminate.

zone of contribution The three-dimensional volumetric part of an aquifer through which groundwater flows to a well from the area contributing recharge. 


\section{Appendix 1. List of Wells Within the Study Area South of the Naval Weapons Industrial Reserve Plant in Bethpage, New York}

Table 1-1. Wells sampled to simulate zones of groundwater contribution in the area south of the Naval Weapons Industrial Reserve Plant in Bethpage, New York.

[Includes identification numbers for New York State Department of Environmental Conservation (NYSDEC) and U.S. Geological Survey (USGS) wells. USGS wells are listed in the National Water Information System (U.S. Geological Survey, 2017d). NA, not available]

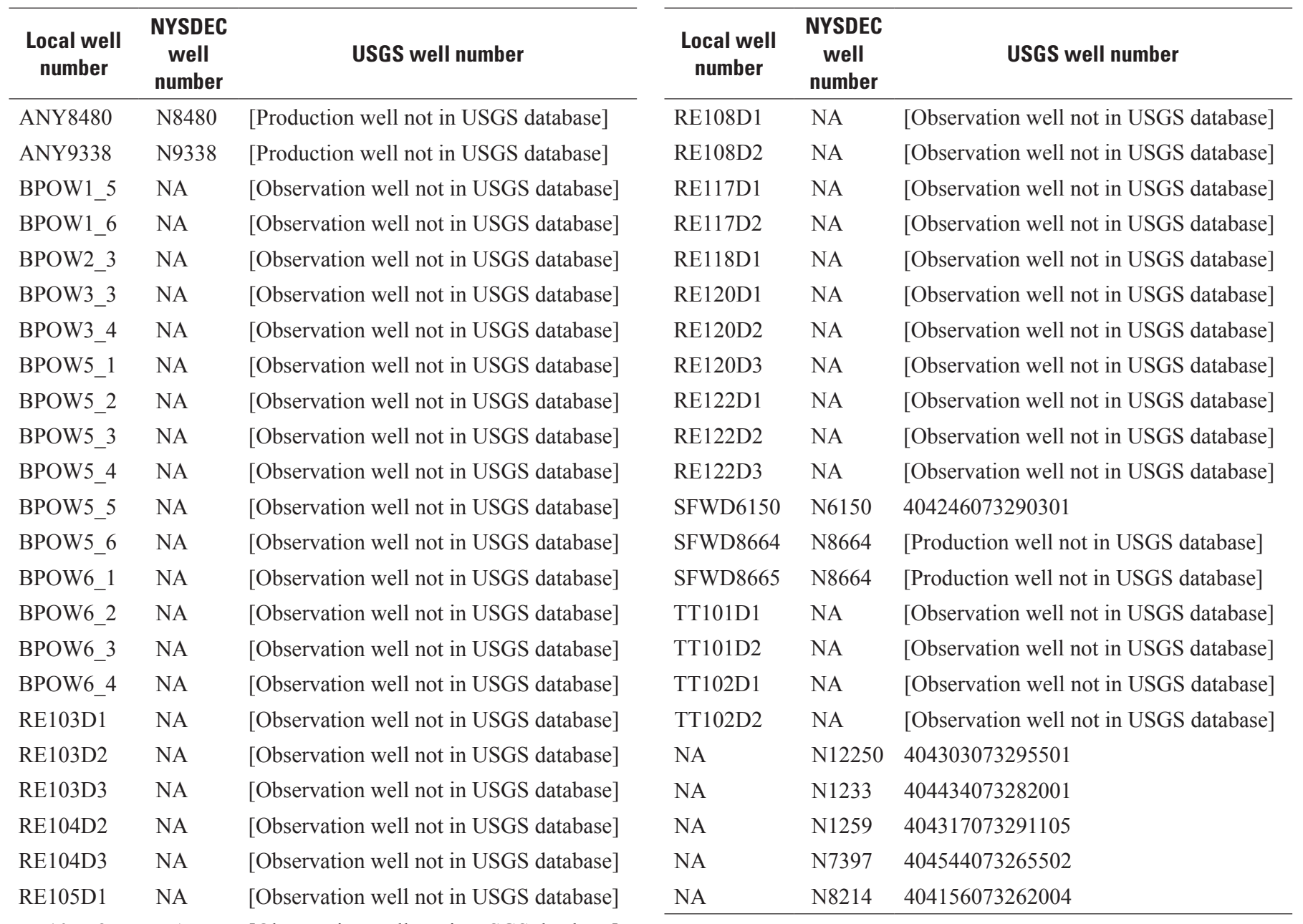



For more information about this report, contact:

Director, New York Water Science Center

U.S. Geological Survey

2045 Route 112, Building 4

Coram, NY 11727

dc_ny@usgs.gov

(518) 285-5602

or visit our website at

https://ny.water.usgs.gov

Publishing support provided by the

Pembroke Publishing Service Center 
宽 